\title{
AN INVESTIGATION OF FAMILY CULTURE IN FAMILY FIRMS' PERFORMANCE IN RETAILER-VENDOR STRATEGIC PARTNERSHIPS
}

\author{
By \\ Leonardo Amado Godoy \\ MBA, Getúlio Vargas Foundation, Brazil, 2013 \\ BBA, Estácio de Sá University, Brazil, 1998
}

\begin{abstract}
A thesis
presented to Ryerson University

in partial fulfillment of the

requirements for the degree of

Master of Science in Management

in the program of

Master of Science in Management
\end{abstract}

Toronto, Ontario, Canada, 2018

CLeonardo Godoy, 2018 


\section{AUTHOR'S DECLARATION}

I hereby declare that I am the sole author of this thesis. This is a true copy of the thesis, including any required final revisions, as accepted by my examiners.

I authorize Ryerson University to lend this thesis to other institutions or individuals for the purpose of scholarly research.

I further authorize Ryerson University to reproduce this thesis by photocopying or by other means, in total or in part, at the request of other institutions or individuals for the purpose of scholarly research.

I understand that my thesis may be made electronically available to the public. 


\title{
AN INVESTIGATION OF FAMILY CULTURE IN FAMILY FIRMS' PERFORMANCE IN RETAILER-VENDOR STRATEGIC PARTNERSHIPS
}

Leonardo Amado Godoy

Master of Science in Management

Ted Rogers School of Management

Ryerson University, 2018

\begin{abstract}
This research proposes a model to measure the effect of family culture on firm performance in family business retailer-vendor strategic partnerships. Prior research that has contributed to the development of the discourse on family culture, organizational culture, family and relationship value, commitment, and trust will be analyzed. Eight hypotheses are presented, four of which are an extension of prior research. The model ratifies a positive relationship between family culture and performance, especially when considering the successor generation. Since the founders of the firm are the personification of the family culture itself, for this group, family culture does not positively influence performance. The outcome of this research will illustrate not only the effects of family culture in family firms' performance, but also the impact of relationship and behavioral factors in business.
\end{abstract}

Keywords: Retail, Family Business, Strategic Partnerships, Organizational Culture, Family Culture, Succession and Performance. 


\section{Acknowledgements}

I would like to express my sincere gratitude to my supervisor Professor Donna Smith who has encouraged and challenged me to pursue my goals since our first meeting. Professor Smith not only provided invaluable guidance throughout the program but also inspired me to be a better person. I always wondered what it would be like to work with a professor in Canada, even at my most optimistic, I could not anticipate working with such a phenomenal supervisor. Special thanks are due to Professor Ojelanki Ngwenyama, for "opening" my mind to science. Additional thanks are due to Professor Frances Gunn and Professor Seung Hwan (Mark) Lee for investing their precious time in reading my work and providing valuable comments. Furthermore, a tremendous thanks for being part of my thesis committee.

During the length of this project we lost the companionship of Professor Richard Michon who provided thoughtful and mindful advice. My thoughts and prayers are with his family.

Ryerson University provided considerable financial support throughout the program. The Ted Rogers Entrance Scholarship as well as Ted Roger School of Management Graduate Student Conference Fund, and the Ryerson Graduate Student Fund are examples of such aid. With this kind of support, I was able to attend an international conference, which contributed to my research in such a positive way. Thanks for investing and believing in me. I am grateful for working with the School of Retail Management, especially Professor Hong Yu and Professor Seung Hwan (Mark) Lee, for inviting me to discuss my work in their research colloquium. 
I am also indebted to Olyvia Testa. She is the perfect definition of a "strategic partnership" that with time has morphed into a lifelong friendship.

My son, Bernardo, my daughter, Julia, and my wife, Marselha. You are the reason I am here and give me the energy that propels me to exceed all expectations I had for myself. Together we are invincible. Mara e Sergio, my godparents. I could not have a better example of such passionate people.

Moreover, I am blessed to have the most amazing family and friends. Luciana and André, special thanks for sharing with me your first roof here in Canada.

I will be always grateful to God and all the love and health that is being received. Last, but definitely not least, my mother, Sonia. You are in a beautiful place praying and watching all of us. After all these years, you are still a constant presence in my life. I miss you. 
This thesis is dedicated to my wife, Marselha.

With you, everything is possible.

You are the love of my life. 


\section{Table of Contents}

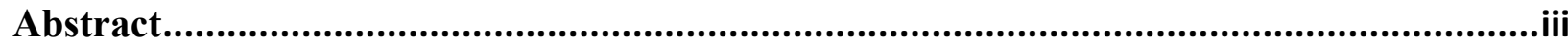

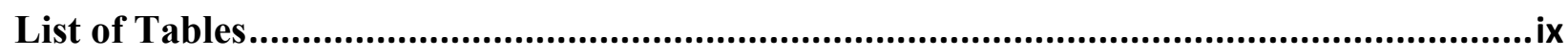

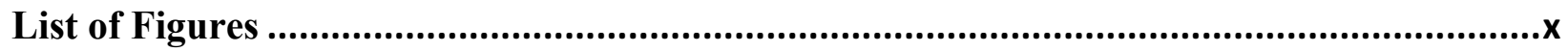

1 Introduction.............................................................................................................. 1

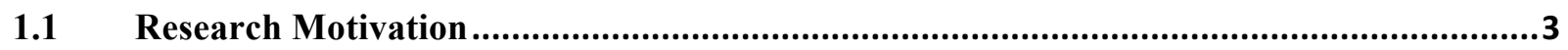

$1.2 \quad$ Retailer-Vendor Strategic Partnerships ..........................................................................

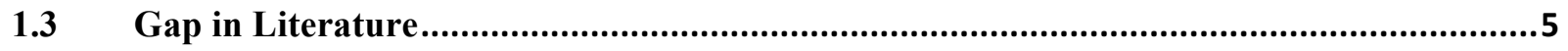

$1.4 \quad$ Research Objective ..............................................................................................

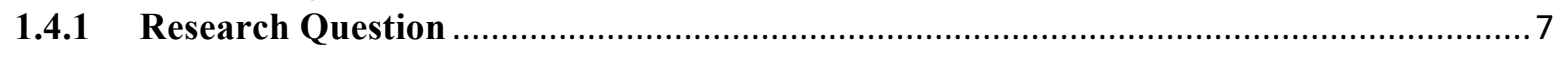

2 Literature Review and Conceptual Framework........................................................ 9

$2.1 \quad$ Organizational Culture.................................................................................................9

2.1.1 Organizational Culture in Family Firms …………….......................................... 12

2.2 Family Culture........................................................................................................16

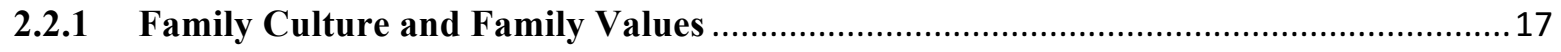

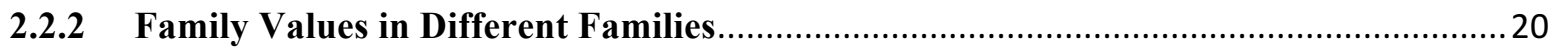

2.2.3 Measuring Family Culture

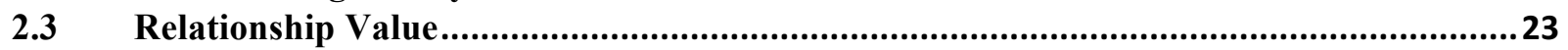

2.4 Commitment .........................................................................................................24

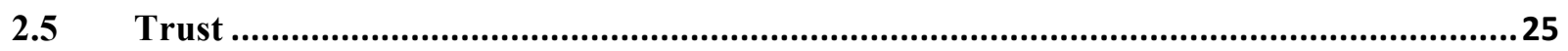

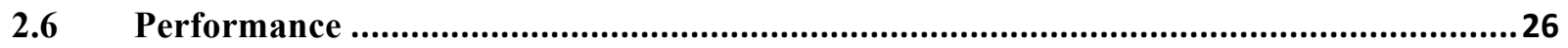

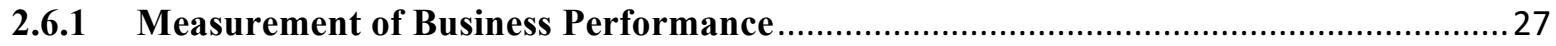

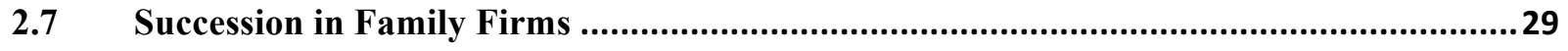

2.7.1 The First Generation (the Founder) .................................................................... 30

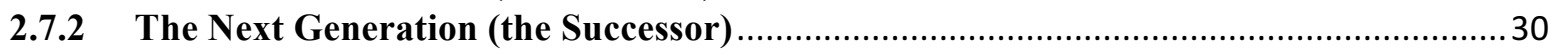

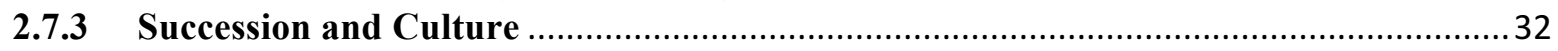

3 Model Development and Hypotheses...............................................................................35

3.1 Prior Research in the Hypothesized Model ………...........................................................36

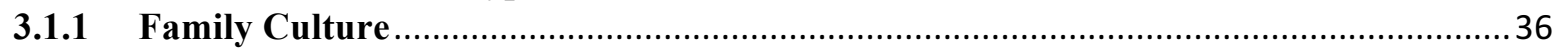

3.1.2 Trust and Commitment ..............................................................................................

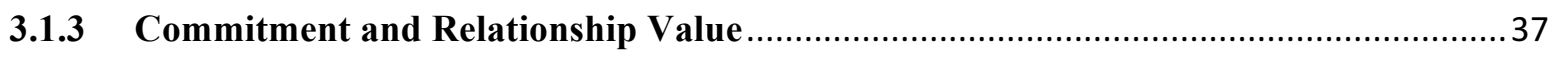

3.1.4 Trust and Relationship Value ..................................................................................

3.2 Extension of Model .........................................................................................................39

3.2.1 Family Culture and Performance …………….......................................................

3.2.2 Family Culture and Relationship Value ……………................................................ 40

3.2.3 Relationship Value and Performance ……………………………………………...... 40

$4 \quad$ Research Methodology ….............................................................................................

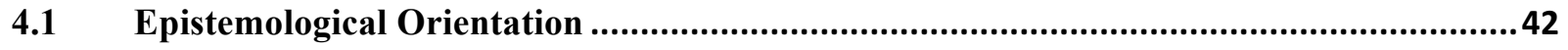

4.2 Measurement of Culture............................................................................................43

4.3 Partial Least Squares Structural Equation Modeling - PLS-SEM ......................................45

4.4 Sample and Data Collection..............................................................................................47 


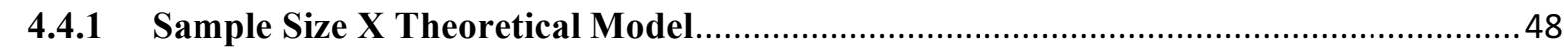

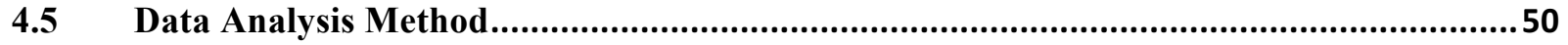

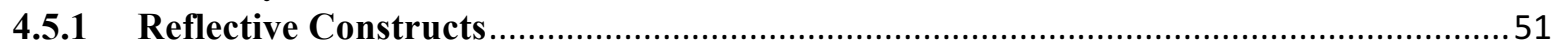

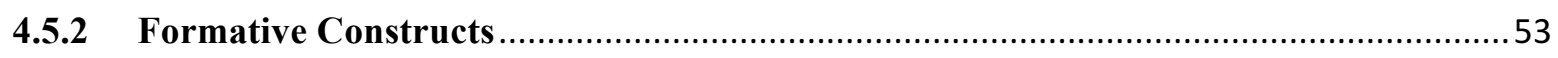

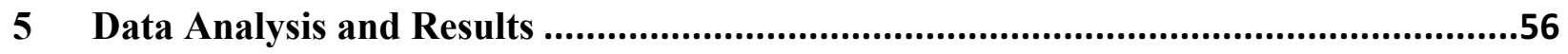

5.1 Assessment of Reflective Measurement Models ........................................................56

$5.2 \quad$ Assessment of Formative Measurement Models ....................................................... 58

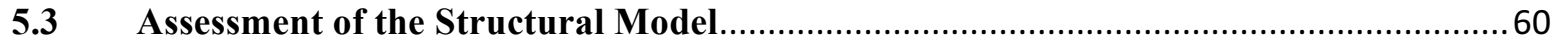

5.4 Assessment of the Measurement Invariance of Composites...........................................64

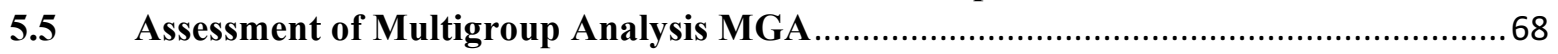

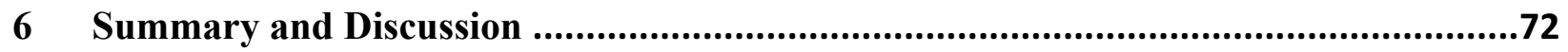

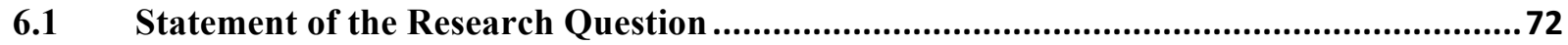

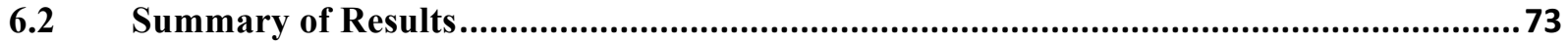

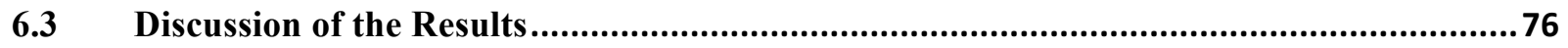

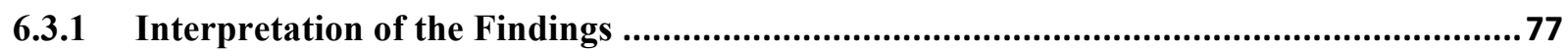

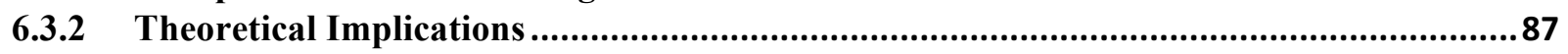

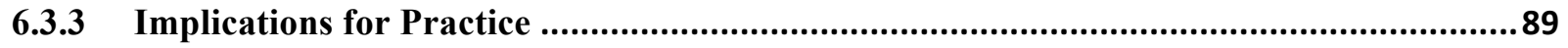

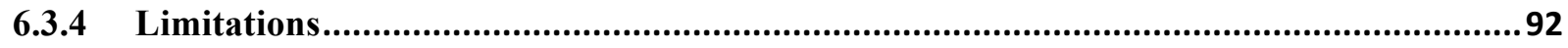

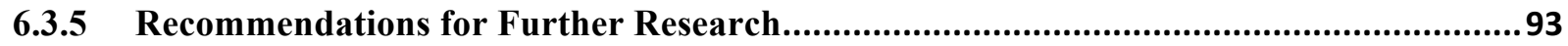

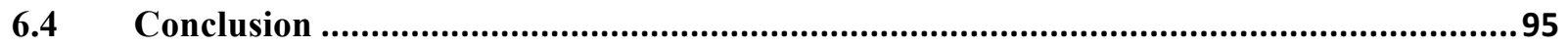

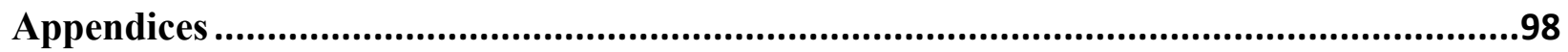

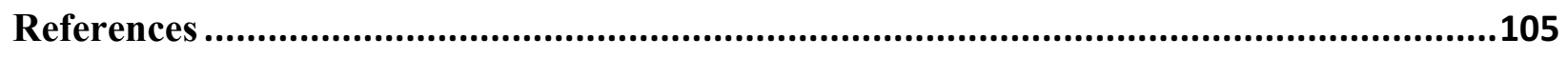




\section{List of Tables}

Table 1: Overview of key findings of selected articles on organizational culture..................................16

Table 2: Overview of key findings of selected articles on family business culture .................................20

Table 3: Sample size recommendation in PLS-SEM for a statistical power of $80 \%$ (Cohen, 1992)..50

Table 4: Results summary for reflective measurement models..........................................................58

Table 5: Results summary for formative measurement models .......................................................59

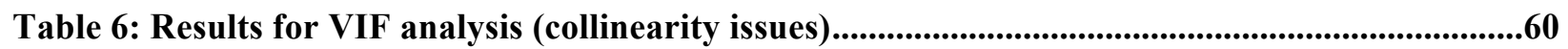

Table 7: Results summary for structural model ...................................................................................64

Table 8: Results summary for MICOM step (2) ............................................................................................67

Table 9: Results summary for MICOM step (2) after composites were removed from the model....67

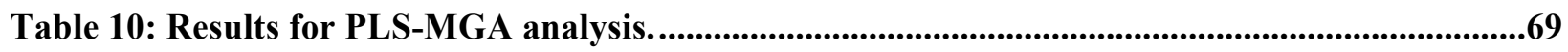




\section{List of Figures}

Figure 1: The F-PEC Culture Subscale (Astrachan et al., 2002)......................................................22

Figure 2: Theoretical Model for the Influence of Family Culture on Performance and Relationship

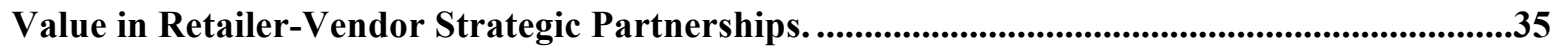

Figure 3: Model with the $R^{2}$ and the significance test results of the paths to the constructs..............63

Figure 4: Question FB2 from the Family Business Questionnaire (Smith et al., 2014)......................65

Figure 5: $\mathbf{R}^{2}$ and the significance test results of the paths to the constructs for Founders data group.

Figure 6: $\mathbf{R}^{2}$ and the significance test results of the paths to the constructs for Successors data

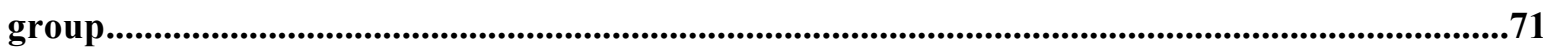




\section{Introduction}

Family firms are not only the most common type of businesses, particularly considering small and medium-sized organizations (e.g., Chirico \& Nordqvist, 2010; Gersick, Davis, McCollom, \& Lansberg, 1997; Westhead \& Howorth, 2007), but are also some of the most resilient organizational structures in the world (Carr \& Bateman, 2010). In particular, family-controlled and family-owned businesses are said to account for $90 \%$ of the United States' incorporated businesses (Poza, 2007). Family firms simultaneously create economic and social wealth, while facing substantial challenges to endure from one generation to the next (Chirico \& Nordqvist, 2010).

The growth of interest and research in family businesses among scholars (Debicki, Matherne III, Kellermanns, \& Chrisman, 2009) is a consequence of the relevance of family business in the global economy. In fact, two thirds of all companies around the world are family enterprises (Englisch, Hall, \& Astrachan, 2015), and 50\%-80\% of global employment is generated by family firms (FFI, 2012). Considering Standard \& Poors $500^{1}$ list of companies and the Fortune $500^{2}$ corporations ranking, one-third originated as family businesses (Chu, 2009). In East Asian countries family firms account for over two-thirds of the economy, and in Western Europe, family firms account for $44 \%$ of the economy (Claessens, Djankov, Fan, \& Lang, 2002).

\footnotetext{
${ }^{1}$ The Standard \& Poor's 500 is an index based on the financial value of 500 large corporations listed on the NYSE (New York Stock Exchange) or NASDAQ (National Association of Securities Dealers Automated Quotations).

2 The Fortune 500 is an annual ranking with the 500 largest corporations in the United States, and it is published by Fortune Magazine.
} 
Furthermore, family firms play a crucial role in dominating the economy of emerging markets, such as in Latin America (Carr \& Bateman, 2010). There is a different level of relevance depending on the part of the world being analyzed; however, despite the region, the relevance of family businesses is well established.

Contrary to predictions made by sociologists (Berle \& Means, 1968) and economists (Galbraith, 1971), who stated that family-owned or family-controlled firms were not viable as an economic institution in the future, there is currently an increasing interest in family firms (e.g., Englisch et al., 2015; Rod, 2016). According to the latter, the increase of interest in family firms is due to the recognition of the economic and personal benefits of families getting together for business purposes. Family firms are relevant, not only because their contribution is crucial for the economy, but also because of their role in current society (Top, Atan, \& Dilek, 2013), since family firms are bringing long-term stability and proving their commitment to local communities.

For decades scholars have been delving into the study of the relationship between family and business organizations. The question proposed by Donnelley (1964) regarding the intricacies and strains of the business environment and whether it is wise to try to preserve family influence in firms is a representation of the perseverance of family firms as a research topic. The definition of "familiness" as the influence of the family on business decisions within family firms (Frank, Kessler, Rusch, Suess-Reyes, \& Weismeier-Sammer, 2016), denotes that the study of the intersection between family and business has been consistently developing. A family will therefore develop grounds to be used as a source for the orientation of their business decisions becoming so intertwined that they merge into a distinct type of business. The result of this 
connection is the acknowledgment of the family business as a complex entity (e.g. Luhmann, 1995; Von Schlippe \& Frank, 2013), which is particularly important when considering that the contemporary world of business is both multi-dimensional and complex (Fletcher, Melin, \& Gimeno, 2012), making it difficult and challenging to survive in this environment.

\subsection{Research Motivation}

Provided below is a testimony that not only evidences how this research intrigued the researcher, but also illustrates how family culture could interact with the day-to-day operations of the organization.

Throughout my professional career, I have worked for a considerable number of distinct organizations one of which was particularly successful. It was not only a large family business but also an organization with a very strong and distinct family culture as its foundation. While I was working for this organization, I realized that the family was always involved in the making of important business decisions. For example, the development of a strategic partnership could only be spearheaded by a family member. In other words, a very protective culture prevented non-family employees to lead relevant projects. As a business man, not part of my own family firm, I was intrigued by the influence that family and family culture have on the success of a business. Leonardo Godoy, March 2017.

However, before exploring the influence of family culture in a family firm, it is imperative that the scenario that will be used to investigate this influence is understood. What is a strategic partnership? What is it purpose? How does it function? Moreover, why are retailer-vendor strategic partnerships relevant? Addressing these questions not only uncovers a definition of 
strategic partnerships, but also sheds light on the particular interest in retailer-vendor strategic partnerships.

\subsection{Retailer-Vendor Strategic Partnerships}

Strategic partnerships have been recognized as a business approach that have been used by firms to gain competitive advantage (Mentzer, Min, \& Zacharia, 2000). The foundation of a strategic partnership is composed of extensive economic, service, technical, and social ties developed over time (Stern, El-Ansary, \& Coughlan, 1996); however, common goals, mutual commitment, and trust must be considered (Dwyer \& Tanner, 2002; Morgan \& Hunt, 1994), in addition to collaboration and communication (Morgan \& Hunt, 1994). A retailer-vendor strategic partnership is a long-standing interfirm alliance that is developed with a broader objective, in other words, the goal of the relationship must go beyond cost reduction (Frazier, Speckman, \& O'Neal, 1988). Due to its contribution to performance, competitiveness, innovation, and organizational learning, strategic partnerships are also considered a business strategy (Smith, Hair, \& Ferguson, 2014).

All in all, strategic partnerships are continuing, long-term relationships that take into account relevant mutual purpose and result in profitability for partners adding value to customers (Mentzer et al., 2000). This paper focuses on retailer-vendor strategic partnerships, which is suggested by Smith et al. (2014, p. 257) to include "the most important vendor or supplier with respect to achieving a higher level of competitiveness over the next 3-5 years." 


\subsection{Gap in Literature}

A reliable theory explaining how family habits and behaviors effect the results of a firm is necessary to truly understand the "family effect" (Dyer, 2006) on firm performance. An older perspective from Hollander and Bukowitz (1990) suggested that a combination of family culture and organizational culture influences the business decision-making process. More recently, Chirico and Nordqvist (2010) provided empirical evidence on how culture affects the relationship between knowledge, dynamic capabilities and an entrepreneurial mindset. Despite the importance of this topic, it is surprising that there is a gap in the literature.

The gap in family business research is concerned with whether family culture improves or thwarts firm performance. In order to investigate this matter, attention must be given to underlying family dynamics (Dyer, 2006). According to Dyer (2006), further investigation of the link between family culture and family firm performance must be undertaken, and more collaboration across management disciplines and the field of family research must be established. Each discipline offers a different perspective and expertise that, when combined, could possibly bridge the gap. Denison, Lief, \& Ward (2004) stated that it is fascinating that scholars are considering culture as part of the family business theoretical framework; however, a link between family culture and performance must be established. The next section of this paper is dedicated to bridging this gap - making it the primary research objective.

\subsection{Research Objective}

Family business is a unique type of organization as well as a singular field of study. Family firms have to deal with inter-personal dynamics that are, most of the time, unusual to non-family organizations (Astrachan, Klein, \& Smyrnios, 2002). Rather than aiming to make a profit, some 
family businesses aim to achieve non-financial returns, such as creating jobs for future generations. In order to be successful then, family firms have to manage family conflicts, as well as create a productive environment (Wilson et al., 2014). Creating and maintaining a productive environment can prove to be challenging especially when considering that contemporary families are changing; hence, family firms are also changing (Holland \& Oliver, 1992). According to Top, Atan, and Dilek (2013) family firms should focus on raising awareness about their relevance, as well as promote the development of a family business framework, in order to help the improvement of family businesses in countries in which family business awareness is less developed. Although family business relevance is a fact (Carr \& Bateman, 2010), its impact is not being explored by top international business journals (Chrisman, Sharma, \& Taggar, 2007). In light of this, the objective of this research is to unearth and emphasize the relevance of family firms as well as family business as a field of research.

Although the importance of family business has been ratified by previous research, the effect of culture on the performance of family firms has not been isolated as its own area worthy of research. A broader investigation regarding whether family ownership is beneficial or detrimental to business performance still remains (Chu, 2009). Research considering the difference in performance between family and non-family firms has not focused on the impact of family on firm performance (Dyer, 2006). The research presented by Dyer (2006) focused on family types and patterns; in addition, the kind of pattern or type that could, eventually, drive better performance. Family dynamics, or culture, are the cause of benefits noticed in family firm performance. Family effect is influenced by family experience, power and culture (Astrachan et 
al., 2002). Family influence or effect (Top et al., 2013) is therefore a crucial element that determines the success and survival of family firms.

An opportunity for developing theories connecting family culture and performance has been established. The main research objective is therefore to investigate the effects of family culture in family firms' performance. With this study, the aim to analyze how family culture affects the performance of family firms in retailer-vendor strategic partnerships. However, before undertaking this investigation, the main research question as well as sub-questions must be stated.

\subsubsection{Research Question}

Since the 1960's, scholars have been proposing questions to understand the implications of family activity in family firms. Donnelley (1964) proposed a list of questions in order to investigate if family management was contrary to free competition. Donnelley was concerned with the equality of opportunity, in other words, if families were looking for the best person for the job (not considering if this person was a family component or not). Moreover, Donnelley was concerned with whether family influence was contrary to all professional management precepts or not. A considerable number of authors (e.g. Casimiro \& Chambel, 2014; Rod, 2016) are still investigating whether the participation of the family in a business has positive or negative effects on the organization; therefore, the question below as stated by Denison et al. $(2004$, p. 61$)$ is still relevant.

"What is that bit of magic that allows a decades-old publicly held company to routinely and confidently demonstrate loyalty to the founders' core beliefs 
and values and yet remain vibrant and on the cutting edge of modern technology and practice?"

This research examines the influence of family culture in retailer-vendor strategic partnerships' outcomes. The following main research question is proposed:

- What is the relationship between family culture and the performance of family firms in retailervendor strategic partnerships?

To expand the research question even further, the following sub-question is proposed:

- Is there a difference in culture as an influencer of performance, in the consideration of different generations in the family firm?

In fact, some authors (e.g. Dyer, 1986; Kansikas \& Kuhmonen, 2008; Zahra \& Filatotchev, 2004) have suggested that family business culture should be studied with the consideration of different generations, since each generation presents different cultural patterns, regardless of working for the same organization (Casimiro \& Chambel, 2014). 


\section{Literature Review and Conceptual Framework}

Previous research concerned with the factors that will inform this study will be extensively reviewed. These areas of research include, but are not limited to, organizational culture, the relationship between family business culture and organizational culture, family values, relationship values, commitment, and trust. It is through this review that the purpose of this study earns validity and merit.

\subsection{Organizational Culture}

The concept of organizational culture has received close attention from scholars and there is a growth in organizational culture literature and interest in management science (Hollander \& Bukowitz, 1990). In order to explore this increase of interest, the work of Schein (1995), Fletcher et al. (2012), and Denison et al. (2004) are insightful. Schein (1995) describes organizational culture as the outcome of employee interactions when grappling with external and internal challenges such as adaptation and integration. When adopted strategies show signs of success, they are transformed into patterns that are taught to new employees as the expected way to respond to challenges.

Another perspective from Fletcher et al. (2012) asserts that a considerable number of studies focus on culture at the level of the organization (e.g., Ainsworth \& Cox, 2003; Astrachan, 1988;

Chirico \& Nordqvist, 2010; Dyer, 1988); in these studies, organizational culture is considered the basic form of conventions that a group learned and developed in order to deal with adaptations and internal integration issues (Schein, 1995). A different approach is defining organizational culture as the intersection of business and family commitment (Corbetta \& Salvato, 2004). 
Finally, Denison et al. (2004) relates corporate culture as component that allows a firm to maintain its initial commitment while remaining competitive in an ever-evolving business environment. It is a great and underexploited opportunity in family firms to retain a connection to the past and simultaneously operate on the cutting edge of technology and management techniques. This clearly identifies the importance of tradition in the operation of family businesses.

Based on these three perspectives it can be concluded that Schein's (1995) definition to organizational culture as the pattern that was created by the organization while dealing with business challenges is very similar to Denison's (2004) definition. If Denison's "kind of magic" is in fact the pattern that is expected to be used to handle business issues, it can be concluded that Schein's (1995) and Denison's (2004) perspectives are somewhat complementary. Fletcher (2012) reverberates those definitions especially at the organizational level; however, instead of defining organizational culture as a set of patterns, he defines it as a basic form of conventions to deal with business issues. Furthermore, those definitions are still up to date. In his most recent book, Schein et al. (2017) defined organizational culture as the set of tested and valid knowledge generated by the firm during its learning process that is transmitted as the right way to deal, reason, and adapt in the face of internal as well as external issues transmitted through generations. It is noted, however, that in this recent definition, Schein et al. (2017) was not only concerned with the patterns or conventions to assess business issues but also with how the knowledge would be transmitted through generations. 
Hofstede (1980) considered that employees could be influenced by either the imposition of management or indirect communication, in an individual and collective way. The McKinsey ${ }^{3}$ approach to culture as "the way we do things around here" was incorporated by Deal and Kennedy (1982); regardless of its potential weakness, strength or acknowledgment, corporate culture exists. However, a strong culture could positively influence performance by permeating employees with a strong sense of purpose that results in remarkable commitment; hence, better performance.

There is another view of corporate culture that acknowledges and applies new learnings over time. This view considers corporate culture as an anchor that carries not only the founders' values and beliefs, but also incorporates new knowledge as the firm operates within the market (Schein, 1985). Furthermore, Goffee and Jones (1998) considered that culture should be analyzed according to the situation, in other words, culture does not consist of absolute and unchangeable behavior; on the contrary, they considered that organization culture is related to relative levels of solidarity and sociability. Kotter and Heskitt (1992) were cited by Denison et al. (2004, p. 63) saying that "Culture refers to values that are shared by people in a group and that tend to persist over time even when group membership changes." A similar approach was embraced by Barney (1986), under the consideration of the impact of core values on the innovation of the firm that influences its longevity.

\footnotetext{
${ }^{3}$ McKinsey \& Company is a consulting firm with offices around the world.
} 


\subsubsection{Organizational Culture in Family Firms}

Culture plays an even more intricate role if the context of family firms is considered (Denison et al., 2004). Values, beliefs, and owner motivations are therefore powerful cultural drivers because the protagonist role of the founder exists from the beginning of the firm, to the entrepreneurial period, and finally to the successive stages of the development of the business. After creating the organization's culture, which is inspired by personal beliefs and represented in the organization's identity and purpose, the founder will influence the succeeding generations to embrace and carry forward those values without relying on hierarchical power. However, to embrace the leader's values as well as to live according to their personal beliefs poses a challenge to successors. The family that succeeds in dealing with this paradox, will, according to Denison et al. (2004), generate superior revenue, in other words, increase performance.

Taking all of this into consideration, family culture and organizational culture are inseparable. The characteristics of family culture will therefore influence organizational culture (Top et al., 2013). Family values could be seen as a type of social power that influence family authority; hence, organizational culture. Characteristics of family culture, family values, as well as the authority of the family are therefore detrimental to organizational culture. In the case of a family firm, strategic decisions about the future of the business are made within the boundaries of its family culture; therefore, when researching family businesses, the overlap between organizational culture and family culture should be considered. If the strategic decisions mentioned above are made on the basis of family culture, then it can be deduced that family culture influences organizational culture which in turn influences performance. 
The main purpose of Table 1: Overview of key findings of selected articles on organizational culture, presented in the following pages is to highlight different perspectives on the definition of organizational culture. Likewise, the table presents articles that discussed similarities between organizational culture and family culture. For example, the 'family' metaphor of organizational culture proposed by Ainsworth \& Cox (2003) moves away from representing a unified entity and is evaluated according to the different parts that make up the family. In this way, the authors explored how 'family' functions in organizational culture, control and resistance. If family members are considered the stakeholders of a family, then Chirico \& Nordqvist's (2010) definition of organizational culture as a set of shared and learned experiences, purposes, values and interpretations that guide stakeholders, can also be applied to define family culture. Finally, considering that a family is an organization that is always changing, the claim stated by Schein et al. (2017), proposing that the concept of organizational culture is continually evolving, over time and contextually, could be applied to define an organization as well as family culture. In this context, it is best understood as the knowledge gathered by the organization or the family, while trying to survive, stay competitive, and integrate with the business environment that surrounds the firm. 


\section{Table 1: Overview of key findings of selected articles on organizational culture}

\begin{tabular}{|c|c|c|c|c|}
\hline $\begin{array}{l}\text { Author(s) } \\
\text { and year }\end{array}$ & Sample & Method & Definition of organizational culture & Key findings \\
\hline $\begin{array}{l}\text { Hofstede } \\
(1980)\end{array}$ & $\begin{array}{l}\text { International attitude } \\
\text { survey from HERMES ( } 66 \\
\text { countries, } 117,000 \\
\text { questionnaires, between } \\
1967 \text { and 1973) }\end{array}$ & $\begin{array}{l}\text { Empirical } \\
\text { (longitudinal } \\
\text { survey) }\end{array}$ & $\begin{array}{l}\text { The collective programming of the mind } \\
\text { which distinguishes the members of one } \\
\text { human group from another. The word culture } \\
\text { is usually reserved for societies (nations) or } \\
\text { for ethnic groups, but it can be applied equally } \\
\text { to other human collectivities: an organization, } \\
\text { a profession, or a family. }\end{array}$ & $\begin{array}{l}\text { Organizations are culture-bound. This applies } \\
\text { not only to the behavior of people within } \\
\text { organizations and to the functioning of } \\
\text { organizations as a whole; even the theories } \\
\text { developed to explain behavior in organizations } \\
\text { reflect the national culture of their author, and } \\
\text { so do the methods and techniques that are } \\
\text { suggested for the management of organizations. }\end{array}$ \\
\hline $\begin{array}{l}\text { Deal and } \\
\text { Kennedy } \\
\text { (1982) }\end{array}$ & Literature and case studies & Conceptual & $\begin{array}{l}\text { A cohesion of values, myths, heroes, and } \\
\text { symbols that has come to mean a great deal to } \\
\text { the people who work at the organization. The } \\
\text { McKinsey perception of culture "the way we } \\
\text { do things around here". }\end{array}$ & $\begin{array}{l}\text { Every company have a strong culture. The } \\
\text { ultimate success of a CEO depends to a large } \\
\text { degree on an accurate reading of the corporate } \\
\text { culture and the ability to hone it and shape it to } \\
\text { fit the shifting needs of the marketplace. }\end{array}$ \\
\hline $\begin{array}{l}\text { Barney } \\
(1986)\end{array}$ & Previous research & $\begin{array}{l}\text { Conceptual } \\
\text { (literature review) }\end{array}$ & $\begin{array}{l}\text { Organizational culture is a complex system } \\
\text { that includes values, beliefs, assumptions, and } \\
\text { symbols according to which a firm functions. } \\
\text { These components of organizational culture } \\
\text { define relevant employees, customers, } \\
\text { suppliers, and competitors as well as } \\
\text { determine how a firm will interact with them. }\end{array}$ & $\begin{array}{l}\text { Persistence and loyalty to a firm's culture can } \\
\text { create and maintain competitive advantage in } \\
\text { the case that the culture has worth, is unique and } \\
\text { is difficult to duplicate. }\end{array}$ \\
\hline $\begin{array}{l}\text { Deshpande } \\
\text { and Webster } \\
\text { (1989) }\end{array}$ & Previous research & $\begin{array}{l}\text { Conceptual } \\
\text { (literature review) }\end{array}$ & $\begin{array}{l}\text { The pattern of shared values and beliefs that } \\
\text { inform behavioral norms within an } \\
\text { organization, as well as demonstrate how and } \\
\text { why things happen. }\end{array}$ & $\begin{array}{l}\text { The understanding of organizational culture is } \\
\text { detrimental in marketing. What happens in } \\
\text { business becomes secondary to why things } \\
\text { happen and how, which is why scholars must } \\
\text { study organizational culture. }\end{array}$ \\
\hline $\begin{array}{l}\text { O'Reilly III, } \\
\text { Chatman, \& } \\
\text { Caldwell } \\
\text { (1991) }\end{array}$ & $\begin{array}{l}\text { Longitudinal data from } \\
\text { accountants and M.B.A. } \\
\text { students and cross- } \\
\text { sectional data from } \\
\text { employees of government } \\
\text { agencies and public } \\
\text { accounting firms. }\end{array}$ & $\begin{array}{l}\text { Organizational } \\
\text { Cultural Profile } \\
\text { (OCP) } \\
\text { questionnaire }\end{array}$ & $\begin{array}{l}\text { Organizational culture determines the extent } \\
\text { to which an individual fits in. }\end{array}$ & $\begin{array}{l}\text { The values of an individual should match the } \\
\text { values of an organization. Therefore, an } \\
\text { assessment of person-organization fit is not only } \\
\text { valid but also necessary. }\end{array}$ \\
\hline $\begin{array}{l}\text { Kotter and } \\
\text { Heskitt } \\
(1992)\end{array}$ & $\begin{array}{l}\text { Theoretical and } 3 \text { case } \\
\text { studies (HP, ICI, and } \\
\text { Nissan) described in the } \\
\text { book }\end{array}$ & $\begin{array}{l}\text { Conceptual and } \\
\text { case studies }\end{array}$ & $\begin{array}{l}\text { Organizational culture has two levels. Culture } \\
\text { refers to values that are shared by the people } \\
\text { in a group and that tend to persist over time } \\
\text { even when a group membership changes, and } \\
\text { also represents the behavior patterns or style } \\
\text { of an organization that new employees are } \\
\text { automatically encourage to follow by their } \\
\text { fellow employees. }\end{array}$ & $\begin{array}{l}\text { Corporate culture can have a significant impact } \\
\text { on a firm's performance. Therefore, corporate } \\
\text { culture is an important factor in determining the } \\
\text { success or failure of firms. Corporate cultures } \\
\text { that constrain strong long-term financial } \\
\text { performance are not rare; they develop easily, } \\
\text { even in firms that are full of reasonable and } \\
\text { intelligent people. Although tough to change, } \\
\text { corporate cultures can be made more } \\
\text { performance enhancing. }\end{array}$ \\
\hline
\end{tabular}




\section{Continuation of Table 1: Overview of key findings of selected articles on organizational culture}

\begin{tabular}{|c|c|c|c|c|}
\hline $\begin{array}{l}\text { Author(s) } \\
\text { and year }\end{array}$ & Sample & Method & Definition of organizational culture & Key findings \\
\hline $\begin{array}{l}\text { Schein } \\
(1995)\end{array}$ & $\begin{array}{l}\text { Personal experience } \\
\text { working as a consultant } \\
\text { with entrepreneurs for } \\
\text { many years. Founders of } \\
\text { three different companies: } \\
\text { "A" - Large chain of } \\
\text { supermarket and } \\
\text { department stores, "B" - } \\
\text { Chain of financial } \\
\text { services, and "C" - } \\
\text { Manufacturing company. }\end{array}$ & $\begin{array}{l}\text { Observation of } \\
\text { entrepreneurs, and } \\
\text { case study. }\end{array}$ & $\begin{array}{l}\text { Invented, discovered, or developed-through- } \\
\text { experience assumptions that help to adapt } \\
\text { when faced with challenges. They must work } \\
\text { well enough to earn validity and to be passed } \\
\text { down as a pattern to deal with such } \\
\text { challenges. }\end{array}$ & $\begin{array}{l}\text { Hybridization is likely the only model of culture } \\
\text { change that can succeed. Core values are highly } \\
\text { community-based and might be difficult for } \\
\text { newcomers to adopt. In this case, newcomers } \\
\text { will either quit or be let go on the basis of } \\
\text { incongruent values. }\end{array}$ \\
\hline $\begin{array}{l}\text { Goffee and } \\
\text { Jones (1998) }\end{array}$ & $\begin{array}{l}\text { Previous scholars, } \\
\text { research, and studies. }\end{array}$ & Conceptual (book) & $\begin{array}{l}\text { Culture is what gives a place its } \\
\text { distinctiveness, and as many are beginning to } \\
\text { realize, it may be your long-term source of } \\
\text { competitive advantage. }\end{array}$ & $\begin{array}{l}\text { Sustained high performance, it turns out, } \\
\text { requires nothing less than a reinvention of the } \\
\text { habitual patterns and processes of organizations. }\end{array}$ \\
\hline $\begin{array}{l}\text { Ainsworth } \\
\text { and Cox } \\
\text { (2003) }\end{array}$ & $\begin{array}{l}02 \text { small firms, with less } \\
\text { than } 20 \text { employees and } \\
\text { more than } 25 \text { years of } \\
\text { existence. }\end{array}$ & $\begin{array}{l}\text { Multiple case } \\
\text { studies (case } \\
\text { records, document } \\
\text { analysis, participant } \\
\text { observation, site } \\
\text { visits and } \\
\text { unstructured } \\
\text { interviews with the } \\
\text { owners) }\end{array}$ & $\begin{array}{l}\text { The 'family' metaphor of organizational } \\
\text { culture moves away from representing a } \\
\text { unified entity and is evaluated according to } \\
\text { the different parts that make up the family. In } \\
\text { this way, we can explore how 'family' } \\
\text { functions in organizational culture, control } \\
\text { and resistance. }\end{array}$ & $\begin{array}{l}\text { With this new approach to understanding the } \\
\text { 'family' metaphor, new insights were gained to } \\
\text { demystify the intersection of family and } \\
\text { organization. Empirical evidence has been } \\
\text { provided to understand the complexity of the } \\
\text { relationship between family and organizational } \\
\text { culture with the dynamics of conflict, control, } \\
\text { and resistance. }\end{array}$ \\
\hline $\begin{array}{l}\text { Denison } \\
\text { (2004) }\end{array}$ & $\begin{array}{l}20 \text { family businesses, and } \\
389 \text { nonfamily businesses }\end{array}$ & $\begin{array}{l}\text { The Denison } \\
\text { Organizational } \\
\text { Culture Survey (at } \\
\text { least } 20 \\
\text { respondents in each } \\
\text { company) }\end{array}$ & $\begin{array}{l}\text { The "bit of magic" in a family firm that } \\
\text { demonstrates loyalty to core beliefs while } \\
\text { promoting technological and practical } \\
\text { advancements that keep a firm competitive. }\end{array}$ & $\begin{array}{l}\text { Family controlled firms have a distinct } \\
\text { performance enhancing culture with results } \\
\text { showing a clear cultural advantage associated } \\
\text { with family owned firms. }\end{array}$ \\
\hline $\begin{array}{l}\text { Carr and } \\
\text { Baterman } \\
(2010)\end{array}$ & $\begin{array}{l}65 \text { of the world's largest } \\
\text { family firms were } \\
\text { compared with } 65 \\
\text { nonfamily firms }\end{array}$ & $\begin{array}{l}\text { Literature review } \\
\text { and a } 20 \text { year } \\
\text { longitudinal data } \\
\text { analysis }\end{array}$ & $\begin{array}{l}\text { Organizational culture represents features that } \\
\text { are not easily duplicated creating a greater } \\
\text { likelihood of long-term performance when } \\
\text { comparing family and non-family businesses. }\end{array}$ & $\begin{array}{l}\text { Family firms and non-family firms are } \\
\text { comparable on the basis of profitability and } \\
\text { sales growth measures. There is no evidence } \\
\text { that performance first increases as family } \\
\text { ownership increases, but then decreases. Rather } \\
\text { a positive effect on performance from family } \\
\text { ownership is indicated in research results. }\end{array}$ \\
\hline $\begin{array}{l}\text { Chirico e } \\
\text { Nordqvist } \\
(2010)\end{array}$ & $\begin{array}{l}04 \text { family firms from } \\
\text { Switzerland and Italy } \\
\text { (beverage sector) }\end{array}$ & $\begin{array}{l}\text { Literature review } \\
\text { and a longitudinal } \\
\text { multiple case study }\end{array}$ & $\begin{array}{l}\text { A set of shared and learned experiences, } \\
\text { purposes, values and interpretations that guide } \\
\text { stakeholders. }\end{array}$ & $\begin{array}{l}\text { Some dynamic markets present firms with a sink } \\
\text { or swim dilemma where firms must unlearn, } \\
\text { relearn and adopt new ways of thinking and } \\
\text { doing business in order to remain competitive. } \\
\text { In other words, companies must develop } \\
\text { dynamic capabilities to survive in such } \\
\text { competitive markets. }\end{array}$ \\
\hline
\end{tabular}


Continuation of Table 1: Overview of key findings of selected articles on organizational culture

\begin{tabular}{|c|c|c|c|c|}
\hline $\begin{array}{l}\text { Author(s) } \\
\text { and year }\end{array}$ & Sample & Method & Definition of organizational culture & Key findings \\
\hline $\begin{array}{l}\text { Fletcher } \\
(2012)\end{array}$ & $\begin{array}{l}47 \text { articles between } 1988 \\
\text { and } 2010 \text { from FBR but } \\
\text { also from JSBM, Journal } \\
\text { of Business Ethics, } \\
\text { Entrepreneurship, Theory } \\
\text { and Practice, and Journal } \\
\text { of Business Venturing. }\end{array}$ & $\begin{array}{l}\text { Conceptual } \\
\text { (literature review) }\end{array}$ & $\begin{array}{l}\text { One of the most powerful and consistent } \\
\text { aspects influencing organizations. }\end{array}$ & $\begin{array}{l}\text { Scholars have yet to understand how } \\
\text { organizational culture creates relations of power } \\
\text { and what backings contribute to such relations. }\end{array}$ \\
\hline $\begin{array}{l}\text { Schein } \\
(2017)\end{array}$ & $\begin{array}{l}\text { Previous scholars, } \\
\text { research, and studies. }\end{array}$ & Conceptual (book) & $\begin{array}{l}\text { The set of tested and valid knowledge } \\
\text { generated by the firm during its learning } \\
\text { process that is transmitted as the right way to } \\
\text { deal, reason, and adapt in face of internal as } \\
\text { well as external issues and it is transmited } \\
\text { through generations. }\end{array}$ & $\begin{array}{l}\text { In order to define abstract concepts such as } \\
\text { culture, scholars must adhere a dynamic } \\
\text { evolutionary perspective. As concept of culture } \\
\text { is continually evoloving, over time and } \\
\text { contextually, it is best understood in this context } \\
\text { as the knowledge gathered by the organization, } \\
\text { while trying to survive, stay competitive, and } \\
\text { integrate with the business environment that } \\
\text { surrounds the firm. }\end{array}$ \\
\hline
\end{tabular}

Table 1: Overview of key findings of selected articles on organizational culture

\subsection{Family Culture}

According to Hollander and Bukowitz (1990, p. 140), adequate forms of behavior within family culture are established over time and pointed to as the recommended way to "think, perceive, and feel". Family culture evolves from the development of those forms of behavior around emotional situations such as distance from family, level of dependency, and level of submission or independence imposed by family. Rules and principles are a consequence of family culture.

Those rules are not questioned; therefore, they are an automatic process. When families get together to start a business, those forms of behavior are also institutionalized in the environment of the family business, in other words, there is no distinction between family culture and business culture. In order to understand the culture of family firms, relationships and the environment must be taken into consideration (Sharma, Chrisman, \& Chua, 1997). Moreover, 
the organizational culture of the family firm will be influenced by family values, rules and principles. Hence, in a family firm, there is no separation between organizational culture and family culture (Top et al., 2013). In conclusion, family culture plays a significant role in influencing business decision-making.

\subsubsection{Family Culture and Family Values}

Values are the foundation of culture (Denison et al., 2004), as a consequence, the type of culture developed in an organization as well as in families depends on what values were established in the first place. Given their complex nature, values should be analyzed as a multi-dimensional construct that evidences several measurement methods (Hogan, 2001). An analysis of beliefs, competitive differentiation, goal achievement, cash profits, and financial and social aids, could be useful for identifying values.

Values might also be considered an enduring belief that a specific type of behavior or a final achievement is individually or collectively preferable to an opposite or converse type of behavior or final achievement (Rokeach, 1973). In other words, this definition suggests that values are a kind of good-manners orientation book.

In this work, both Rokeach's (1973) and Denison's et al. (2004) approach to value are used since primary focus is placed on the factors or attributes that generate culture by means of recognizing that the most relevant values of a family firm are a consequence of how active a family is in the business. The first purpose of Table 2: Overview of key findings of selected articles on family business culture, presented in the following pages, is to validate the research question. For example, Hollander and Bukowitz (1990) claimed that family business is an extension of family culture; therefore, it is important to understand tradition and its effects on the family firm 
because it might not always lead to the best business decision. The role of the founder, as the one responsible for fostering the values that will give rise to the family culture was highlighted by Denison et al. (2004). Finally, the relevance of this investigation was evident in one of the conclusions from Top et al. (2013) confirming that family culture affects business decisions. The second and main purpose of Table 2 is to ratify the relevance of values as part of the foundation of family culture. In fact, Dyer (1988) attested that a combination of values and assumptions create a unique harmony upon which a business is run. When values are combined with family history, social relations, and beliefs, the outcome is family culture (Chirico \& Nordqvist, 2010). To demonstrate the importance of values as part of family culture, an overlap between firm values and family values was highlighted by Top et al. (2013). Finally, in a more recent study, Jaskiewicz et al. (2016) proposed that family culture is not only composed of the set of shared family values and norms, but also the way the firm communicates. They concluded that a cohesive family culture reveals the importance of family values as the foundation of the family firm. 


\section{Table 2: Overview of key findings of selected articles on family business culture}

\begin{tabular}{|c|c|c|c|c|}
\hline $\begin{array}{l}\text { Author(s) } \\
\text { and year }\end{array}$ & Sample & Method & Definition of family business culture & Key findings \\
\hline $\begin{array}{l}\text { Davis } \\
(1983)\end{array}$ & $\begin{array}{l}366 \text { complete surveys } \\
\text { from } 1,100 \text { business } \\
\text { employees from both } \\
\text { family and non-family } \\
\text { firms }\end{array}$ & Web-based survey & $\begin{array}{l}\text { When stewardship exists within the family } \\
\text { business. The existence of stewardship not } \\
\text { only produces strong family business } \\
\text { culture but is also linked to positive } \\
\text { performance. }\end{array}$ & $\begin{array}{l}\text { Family member employees observe commitment, } \\
\text { trust, and stewardship than non-family members. } \\
\text { "Blood is thicker than water". }\end{array}$ \\
\hline Dyer (1988) & 40 family firms & $\begin{array}{l}\text { Data from corporate } \\
\text { histories, annual } \\
\text { reports, memos, } \\
\text { interviews and minutes } \\
\text { of board of directors } \\
\text { meetings. } \\
\end{array}$ & $\begin{array}{l}\text { A combination of values and assumptions } \\
\text { that create a unique harmony upon which a } \\
\text { business is run. }\end{array}$ & $\begin{array}{l}\text { Business leaders must foster cultural patterns } \\
\text { conducive to growth. Strong family firm culture is } \\
\text { only possible when the leader strives for continuity, } \\
\text { as well as the best interest of their families. }\end{array}$ \\
\hline $\begin{array}{l}\text { Hollander } \\
\text { and } \\
\text { Bukowitz } \\
(1990)\end{array}$ & Previous studies & $\begin{array}{l}\text { Conceptual (literature } \\
\text { review) }\end{array}$ & $\begin{array}{l}\text { Family business culture is developed } \\
\text { through behavioral patterns that stem from } \\
\text { emotional issues that are passed down and } \\
\text { replicated in, or influence, the family } \\
\text { business. }\end{array}$ & $\begin{array}{l}\text { Family business is an extension of family culture. } \\
\text { Understanding tradition and its effects on the } \\
\text { family business is important as it might not always } \\
\text { lead to the best business decision. }\end{array}$ \\
\hline $\begin{array}{l}\text { Sharma, } \\
\text { Chrisman } \\
\text { and Chua } \\
\text { (1997) }\end{array}$ & Previous research & $\begin{array}{l}\text { Conceptual (literature } \\
\text { review) }\end{array}$ & $\begin{array}{l}\text { Family business culture can be analyzed } \\
\text { according by type (paternalistic, laissez- } \\
\text { faire, participative, professional). In order to } \\
\text { understand family firm culture in this } \\
\text { manner, human nature, relationships and the } \\
\text { environment must be taken into } \\
\text { consideration. }\end{array}$ & $\begin{array}{l}\text { Families relationships at home may differ from } \\
\text { family relationships at work. Furthermore, } \\
\text { relationships vary and are complex, hence there is } \\
\text { no ideal relationship upon which to measure the } \\
\text { validity and influence of one family relationship on } \\
\text { business over another. }\end{array}$ \\
\hline $\begin{array}{l}\text { Astrachan et } \\
\text { al. (2002) }\end{array}$ & $\begin{array}{l}\text { Previous studies and } \\
\text { research }\end{array}$ & $\begin{array}{l}\text { Literature review. } \\
\text { Validate the model } \\
\text { through a focus group } \\
\text { discussion and a pilot } \\
\text { testing on a number of } \\
\text { family business } \\
\text { owners. }\end{array}$ & $\begin{array}{l}\text { When family and business have goals and } \\
\text { values in common. }\end{array}$ & $\begin{array}{l}\text { How families gain, lose, or maintain influence in } \\
\text { business can be understood by applying the F-PEC } \\
\text { scale. }\end{array}$ \\
\hline $\begin{array}{l}\text { Corbetta e } \\
\text { Salvato } \\
\text { (2004) }\end{array}$ & Previous research & $\begin{array}{l}\text { Conceptual (literature } \\
\text { review) with F-PEC } \\
\text { model proposal }\end{array}$ & $\begin{array}{l}\text { Family business culture happens when the } \\
\text { values of each overlap in conjunction with a } \\
\text { similar business goal. }\end{array}$ & $\begin{array}{l}\text { External influence will create pressure for family } \\
\text { firms to expand. Opinions from family involvement } \\
\text { should be explicitly taken into consideration in } \\
\text { matters of expansion and development, in order to } \\
\text { avoid external influence to infiltrate the family } \\
\text { firm. }\end{array}$ \\
\hline $\begin{array}{l}\text { Denison } \\
(2004)\end{array}$ & $\begin{array}{l}20 \text { family businesses, } \\
\text { and } 389 \text { nonfamily } \\
\text { businesses }\end{array}$ & $\begin{array}{l}\text { The Denison } \\
\text { Organizational Culture } \\
\text { Survey (at least } 20 \\
\text { respondents in each } \\
\text { company) }\end{array}$ & $\begin{array}{l}\text { Family business culture stems from the } \\
\text { founder who fosters the development of } \\
\text { values and performance throughout the } \\
\text { stages of the business, hence maintaining } \\
\text { influence on the business culture. }\end{array}$ & $\begin{array}{l}\text { Family controlled firms have a distinct } \\
\text { performance enhancing culture with results } \\
\text { showing a clear cultural advantage associated with } \\
\text { family owned firms. }\end{array}$ \\
\hline $\begin{array}{l}\text { Chirico e } \\
\text { Nordqvist } \\
(2010)\end{array}$ & $\begin{array}{l}04 \text { family firms from } \\
\text { Switzerland and Italy } \\
\text { (beverage sector) }\end{array}$ & $\begin{array}{l}\text { Literature review and a } \\
\text { longitudinal multiple } \\
\text { case study }\end{array}$ & $\begin{array}{l}\text { A combination of history, social relations, } \\
\text { beliefs and values of and within a family } \\
\text { business. }\end{array}$ & $\begin{array}{l}\text { Diversification is not only important in family } \\
\text { business culture, but necessary. Tradition is } \\
\text { important, however, change according to the } \\
\text { environment is crucial for continued success, even } \\
\text { though it might not always be the best option. }\end{array}$ \\
\hline
\end{tabular}


Continuation of Table 2: Overview of key findings of selected articles on family business culture

\begin{tabular}{|c|c|c|c|c|}
\hline $\begin{array}{l}\text { Author(s) } \\
\text { and year }\end{array}$ & Sample & Method & Definition of family business culture & Key findings \\
\hline $\begin{array}{l}\text { Bjursell } \\
(2011)\end{array}$ & $\begin{array}{l}02 \text { family firms from } \\
\text { Nordic region }\end{array}$ & $\begin{array}{l}\text { Organizational } \\
\text { ethnography study } \\
\text { with } 200 \text { interviews } \\
\text { and } 40 \text { h of video } \\
\text { observation }\end{array}$ & $\begin{array}{l}\text { Business culture can be seen and defined as } \\
\text { both a variable and a context. As the } \\
\text { former, it can be measured and fragmented; } \\
\text { as the latter, it can be a basis for } \\
\text { argumentation in a study. Culture is to be, } \\
\text { not to have. }\end{array}$ & $\begin{array}{l}\text { Expansion and growth of a business means that } \\
\text { new non-family employees become a part of the } \\
\text { team. Over time this will start to influence the core } \\
\text { values that once formed the basis of the business } \\
\text { (organizational culture). }\end{array}$ \\
\hline $\begin{array}{l}\text { Top, Atan } \\
\text { and Dilek } \\
\text { (2013) }\end{array}$ & $\begin{array}{l}244 \text { family firms from } \\
\text { Istanbul }\end{array}$ & $\begin{array}{l}\text { F-PEC scale, } 68 \\
\text { questions survey }\end{array}$ & $\begin{array}{l}\text { Developed beliefs and shared values. Being } \\
\text { both a family and a business means that } \\
\text { there will be an overlap of firm values and } \\
\text { family values. }\end{array}$ & $\begin{array}{l}\text { Although it might be that a correlation between } \\
\text { culture control and capital control within a firm } \\
\text { does not exist, family members on a board of } \\
\text { directors has positive effects on both short- and } \\
\text { long-term activities. In other words, capital does } \\
\text { not effect the culture and relationships of a family } \\
\text { business but family culture effects business } \\
\text { decisions. }\end{array}$ \\
\hline $\begin{array}{l}\text { Jaskiewicz, } \\
\text { Heinrichs, } \\
\text { Rau and } \\
\text { Reay }(2016)\end{array}$ & $\begin{array}{l}21 \text { cases of family firms } \\
\text { from Germany }\end{array}$ & $\begin{array}{l}\text { Interviews with family } \\
\text { members from the } 21 \\
\text { sampled firms, as well } \\
\text { as with induustry } \\
\text { experts }\end{array}$ & $\begin{array}{l}\text { A family culture is not only composed of } \\
\text { the set of shared family values and norms, } \\
\text { but also the way the firm communicates. A } \\
\text { cohesive family culture reveals the } \\
\text { importance of family logic in the family } \\
\text { firm. }\end{array}$ & $\begin{array}{l}\text { Identifying the relationship between family culture } \\
\text { and leadership style reveals how a family firm } \\
\text { performs according to family logic. }\end{array}$ \\
\hline
\end{tabular}

Table 2: Overview of key findings of selected articles on family business culture

\subsubsection{Family Values in Different Families}

Other scholars approach family culture as family dynamics (Dyer, 2006). For instance,

Constantine (1993) and Kantor and Lehr (1975) classified four types of families, depending on

the dynamics and paradigms represented by the family. The first one is the closed paradigm

family, where hierarchy of authority determines the decision process. The second type of family

is the random paradigm, in which values are not constants, rather they evolve and innovate. This

kind of family is a democratic environment, where components are encouraged to provide ideas

and actions to represent the family; thus, individual initiative is the way to achieve collective

needs. The third type of family is the open paradigm. This type is also a democratic 
environment; however, in this type of family, individual needs are mixed with business goals. The fourth and last type of family is the synchronous paradigm. The rules of the family are well known by all components; therefore, participants are very pro-active since they do not require an orientation about what to do. Such a family classification may be useful to understand why some family businesses have a comparative advantage and others do not (Dyer, 2006).

Another relevant perspective comes from Fletcher et al. (2012), who is concerned with the ways in which culture influences business processes. In order to adequately grasp this perspective, Fletcher provides evidence on the influence of culture in business processes, which includes divestment decisions (Sharma \& Manikutty, 2005), performance (Corbetta \& Salvato, 2004), succession (Dyer, 1988), and obtaining competitive advantage (Carr \& Bateman, 2010). Therefore, studies in family business culture focus firstly on 'what the culture is', secondly on 'what culture can do' for the family firm, and thirdly on the identification of factors that shape culture (Fletcher et al., 2012).

\subsubsection{Measuring Family Culture}

There are three different perspectives on how to deal with culture in the field of family business. These perspectives include culture as a variable, culture as a context, and culture as a research approach (Bjursell, 2011). When researchers assume that culture can be measured as a variable or even separated into subcomponents, they are using the variable perspective. Furthermore, the variable perspective assumes that cultural dimensions may be managed and changed (Smircich, 1983). This perspective implies that culture is one of several variables; hence, it is divisible and can be broken into multiple subcomponents. One implication of this nature of culture is that it requires an appropriate method of measurement. 
On the contrary, when researchers use culture as an argument to perform the research, they exploit the context perspective (Bjursell, 2011). This study not only adheres to the context perspective, but also aims to identify the influence of culture in family firms, in other words, 'what culture can do' for the family firm (Fletcher et al., 2012).

Furthermore, if a definition of family business "must be unambiguous and transparent in such a way that it can be quantified"' (Klein, Astrachan, \& Smyrnios, 2005, p. 322), the culture subscale from the F-PEC scale of family influence, as seen in Figure 1, could be applied as a means to avoid any chance of ambiguity or lack of transparency. Astrachan et al. (2002) ratifies this point by suggesting that a method of measurement will facilitate thorough and rigorous analysis across all investigations taking into consideration all possible variables.

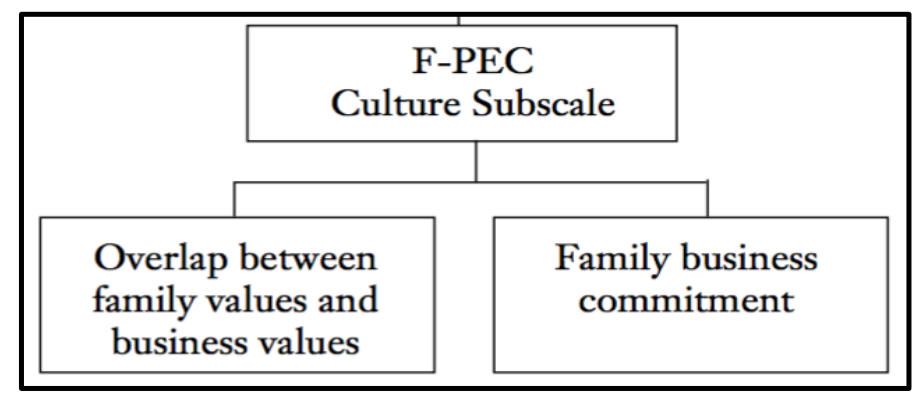

Figure 1: The F-PEC Culture Subscale (Astrachan et al., 2002).

After exploring the relevant literature available on organizational and family culture respectively, the remainder of the literature review will cover previous studies on relationship value, commitment, trust, and performance. These are the constructs that are going to be used in the conceptual model. In addition to analyzing previous research conducted on each of the constructs, a review of the literature on generations and succession in family business will be 
provided. As will be explained in greater detail in section 6.1, one of the main research questions will investigate the perception of family culture across different generations in the family firm, validating the necessity of this literature review.

\subsection{Relationship Value}

Nowadays, a considerable number of firms are gaining competitive advantage by developing close, cooperative relationships with specific suppliers and customers (Hogan, 2001). In order to develop these strategic relationships, managers must consider questions regarding which partner to select, how to manage the relationship, how to generate value from this relationship, as well a method to evaluate this relationship. Marketing scholars gathered a set of reasons that organizations mention as an effect of strategic partnerships; in fact, most of those organizations cited cost reduction as the main reason to establish a strategic relationship (Hogan, 2001).

Relationship value has been defined as a set of trade-offs that took place in a competitive environment in a model that included commitment and trust (Ulaga \& Eggert, 2006). An updated version of this definition stated that relationship value is a set of trade-offs that considers accessible options and outcomes in the achievement of mutual goals (Smith et al., 2014). Therefore, through the study of those mutual goals, competitiveness, and profitability (Vázquez, Iglesias, \& Álvarez-González, 2005), the strategic partnership is not only considered as a set of trade-offs, but also as a source of competitive advantage; hence, value creation.

In this study, relationship value is being considered as a source of competitive differentiation (Smith et al., 2014) to understand the influence of family culture, in all of its aspects, on organizational culture, thus performance. 


\subsection{Commitment}

Commitment is a relevant subject and has been studied at both the individual and organizational level (Riketta, 2002). Commitment is a binding power that is either felt as a mindset or as a psychological state that influences a person to act in a specific way (Meyer \& Herscovitch, 2001). Some scholars believe that individuals identify with commitment to and involvement in a particular organization; hence the acceptance of its specific goals and values (Mowday, Porter, \& Steers, 1982). Thus, commitment illustrates a solid connection or a binding relationship; therefore, commitment affects behavior (J. Davis, Allen, \& Hayes, 2010). Relationship commitment, which is the focal point to all interpersonal interactions between the firm and its partners, was defined by Morgan and Hunt (1994) as the recognition of the importance of an exchange partner in such a way that the organization will apply all resources and efforts in order to maintain this relationship.

In family firms, relationships are considered a crucial point, and this relevance has resulted in a considerable number of different measures for commitment (Smith et al., 2014). Study results concluded that high levels of family participation and ownership had a positive impact on the relationship between employees and reinforced the bond between the employees and the firm itself. According to Smith et al. (2014), commitment could also be approached as a multidimensional phenomenon. Smith cited Morgan and Hunt (1994) and their relationship commitment scale, which was developed from literature on social exchange, marriage, and organizational commitment. A different perspective to define commitment was proposed by Allen and Meyer (1990) and according to their study, the definition of commitment could also be interpreted as a tripartite (Allen \& Meyer, 1990), knowledgeable measure tool, especially in 
family business literature (e.g., Sieger, Bernhard, \& Frey, 2011; Vallejo \& Langa, 2010; Zahra, Hayton, Neubaum, Dibrell, \& Craig, 2008). Affective commitment, such as marriage for example (Allen \& Meyer, 1990), points out the difference between levels of commitment amongst individuals. When individuals are working in family organizations they tend to present a higher level of commitment compared to a non-family organization (Vallejo \& Langa, 2010).

Smith et al. (2014) concluded that, despite the differences in commitment perspective and how to measure it, it is clear that commitment positively influences family firms. Commitment will be considered in this study in the same way that relationship value was considered, as a source of competitive differentiation, especially for family organizations.

\subsection{Trust}

Several authors defined trust as the "willingness of a party to be vulnerable to the actions of another party based on the expectation that the other will perform a particular action important to the trustor, irrespective of the ability to monitor or control that other party" (Mayer, Davis, \& Schoorman, 1995). Other authors pointed out that trust can be higher in family firms because of the use of "family language", a result of family relationships (Tagiuri \& Davis, 1996). Due to the efficacy of information exchange within families, family members are capable of demonstrating trust through their will to be vulnerable to another family member. According to Morgan and Hunt (1994, p. 23), trust exists when "one party has confidence in an exchange's partner reliability and integrity".

If the subject is isolated and the definition of trust in the context of family business literature is analyzed, then trust is considered an integration of psychological, organizational, and interorganizational processes (e.g., Eddleston, Chrisman, Steiler, \& Chua, 2010; Rousseau, Sitkin, 
Burt, \& Camerer, 1998). Trust is therefore a very relevant subject within the realm of family business literature. Children could demonstrate a sense of safety and protection by increasing their effort to impress parents; this relation is categorized as parent-child trust (Lumpkin, Martin, \& Vaughn, 2008). If applied in a business environment, the parent-child trust relation increases profitability; hence, providing a competitive advantage for the firm (Chami, 2001). Trust has multiple functions, for instance, without trust there is no transparency. Furthermore, with trust employees share a sense of belonging, people increase their sense of ownership, and finally, relationships are strengthened (Sundaramurthy, 2008). Both family and non-family stakeholders recognize that these are the main reasons for considering trust as a valuable asset.

The model proposed in this work positions trust between family culture and relationship value; hence, as a driver of performance. The model also positions trust as an influencer of commitment (Smith et al., 2014).

\subsection{Performance}

Many scholars hold the position that performance covers a wide range of activities, such as performing arts, sports, religion, show-business, and performance in everyday life (Schechner, 1988). In other words, some scholars believe that performance exists in an overlapped space between "transgression" and "resistance" models (McKenzie, 2001). Accepting the multiplicity of meanings of performance, different authors studied performance from different perspectives. Goffman (1959) relates performance to the kind of "social mask" that individuals may use in different situations of life. More recently, Connor (1996) suggested two different approaches to comprehend performance. The first one is about the sense of acting, and the second one is related to the sense of playing out, or "impersonating". According to Phelan (1993), performance can 
neither be documented nor related to representations, rather, it signifies the interaction between individuals in real life.

\subsubsection{Measurement of Business Performance}

The consideration of performance in a business environment leads one to the conclusion that there is no a definitive, agreed upon definition of performance or even a basic terminology (Venkatraman \& Ramanuja, 1986). Furthermore, a wide range of conceptions from efficiency, to resilience and even return of investment (ROI) are accepted (Lebas, 1995). In his study about performance measurement and performance management, Lebas (1995) stated that performance is not related to the past, rather it is connected to the future, in other words, to the capacity of the firm to be evaluated. Moreover, a performing business is one that will achieve goals set for the future according to unique parameters enforced by the managers. This emphasizes the need to move away from attempting to objectively define performance and embrace the challenge of defining, and measuring, the performance of individual businesses according to their own conceptions of performance.

It has also been previously stated that family businesses do not only aim to make a profit, but also seek non-financial returns. In order to be successful then, family firms have to manage family conflicts, as well as create a productive environment (Wilson et al., 2014).

Performance permeates life; in fact, it exists in every situation, business or leisure, in which is put forth effort (Folan, Browne, \& Jagdev, 2007). According to Folan et al. (2007), despite all the research dedicated to business performance, the concept of performance remains unclear. 
Interestingly, Folan et al. (2007) suggests that some truths about performance have been subconsciously accepted under the presumption that people know what performance is.

Based on the understanding that scholars and practitioners seem to have different conceptions of performance, an important question still remains - have anyone ever tried to analyze every conception that exists? Folan et al. (2007) introduces the idea of a kaleidoscoping effect when considering the definition of performance. This means that just like the colored beads and mirrors of a kaleidoscope react with light to create different varieties of patterns and images, so does performance when applied to varying contexts. Depending on how much light shines into a kaleidoscope the image and image quality changes. Similarly, depending from which angle performance is analyzed (individual, group, personal or impersonal; good, bad, or improved; specific or vague) the outcome is also different. To minimize the possibility of ambiguity it is clearly evident that a common definition of the term, despite the simplicity of the term itself, must be established. Being that it is not an easy feat, few scholars have undertaken this mission.

Since performance is being measured, a strategic management perspective (Venkatraman \& Ramanuja, 1986), which is aimed at measurement aspects, must be considered. Hofer (1983) pointed out that, depending on the discipline, different types of measurement will be applied to measure firm performance. Venkatraman \& Ramanuja (1986) considered business performance as a subset of the organization's effectiveness, and financial performance as a subset of business performance. Venkatraman \& Ramanuja (1986, p. 803) defined financial performance as "simple outcome-based financial indicators that are assumed to reflect the fulfillment of the economic goals of the firm". 
This work not only adheres to Venkatraman \& Ramanuja's perspective, but also to Hult's et al. (2003, p. 430) definition of performance that describes performance as "the achievement of organizational goals related to the profitability and growth in sales and market shares, as well as the accomplishment of general firm strategic objectives."

Furthermore, if a family firm is considered as a kind of investment, performance could be used to verify how profitable a family firm is. In conclusion, this study considers that a family firm's performance is explicit; therefore, measurable.

\subsection{Succession in Family Firms}

Succession in a family business is, by definition, a process that transfers the management and ownership of the firm to the next generation (Cadieux, Lorrain, \& Hugron, 2002). In fact, succession is, according to scholars in the field of family business, the most relevant challenge that family organizations must consider (Handler, 1994). For instance, Ward's (1987, p. 252) definition of family business is based on the acknowledgment of succession as a main element of a family organization: "we define a family business as one that will be passed on for the family's next generation to manage and control'. Succession in a family firm is different than succession in a non-family firm due to the fact that nonbusiness issues as well as family participation and emotional involvement are included in the succession process of a family firm (Sharma, Chrisman, \& Chua, 2003).

During the succession process, family relationships are re-constructed, influential power is transferred, and the organizational structures are replaced. In other words, the succession process imposes severe changes to the family as well as the firm (Lansberg, 1988). Beckhard and Dyer (1983a) pointed out that only $30 \%$ of family organizations succeed the transition of control to 
second-generation successors. Considering the transition to the third generation, the number drops considerably to $10 \%$.

A crucial point that determines the success of the succession process is family dynamics

(Handler, 1994). In addition, the social skills of a leader, family preparation, and firm

development are important as well (P. Davis, 1986). Employees, suppliers, and customers of the firm that is under the succession process feel threatened by the change (Lansberg, 1988).

Managers feel threatened due to the shift of command as well as the relationship shift, from personal with the founder to a professional relationship with the successor.

\subsubsection{The First Generation (the Founder)}

A sense of indispensability in relation to the firm, a constant need for achievement, control and power, are cited by scholars as the main characteristics of founders of family firms (Becker, 1973; McClelland, 1961; Shapero, 1975). In a symbolic analogy, the founder and the firm are the same entity; the business is, therefore, the link of the founder with reality (Zaleznik \& Kets de Vries, 1985). Dyer (1986) concluded that the sense of immortality and the need for control and power are entrepreneurial in nature; therefore, during the succession process, founders have difficulty with giving up on what they have created - the firm itself. However, if the survival of the firm depends on the transfer of power to the next generation, the quality of relationship between the founder and the successor are crucial to determine the successful completion of the process (Cabrera-Suarez, De Saa-Perez, \& Garcia-Almeida, 2001; Handler, 1994).

\subsubsection{The Next Generation (the Successor)}

The successor generation, contrary to that of the founder, has to deal with an established culture when they assume their position in the family firm. According to Gersick et al. (1997, p. 149) 
"the family is perhaps the most reliable of all social structures for transmitting cultural values and practices across generations". In fact, with the implementation of appropriate methods to communicate its essence, the company's culture can survive for many generations.

A framework was developed by Handler (1994) to describe the factors that influence the success rate of the generation of successors during the succession process. The more the successors achieve their career goals, and fulfill psychological and life stage needs, the more the succession process tends to succeed. The more the successor has the opportunity or the capability to impose personal influence as well as the achievement of mutual respect between successor and founder, the more positive the succession process will be. Scholars noticed that integrity and commitment to the business are the most valuable characteristics of successors (Chrisman, Chua, \& Sharma, 1998; Sharma \& Rao, 2000). Handler (1994) concluded that the greater the commitment to perpetuate the family culture as well as values, the greater the chances of a positive outcome from the succession experience.

Cater et al. (2016) identified four groups of factors that influence the decision of the successor to get into the family firm. These factors include the history of the business itself, the professional experience of the successor, the quality of family interactions, and a direct invitation from the founder of the firm. When those factors co-exist, the opportunity to adhere to the family firm becomes more attractive to successors. In summary, a successor must be prepared to assume the position in the family firm (Brun, Wrosch, \& Gagne, 2007); must be capable and interested in performing the designed function (Birley, 2002); must be fully committed to the process of succession and willing to accept the changes (Barach \& Gantisky, 1995); and must be trained, skilled and, most importantly, 
experienced (Barach, Gantisky, Carson, \& Doochin, 1988; Morris, Williams, Allen, \& Avila, 1997).

Taking into consideration the successors perspective regarding professional experience, to have the opportunity to work for other organizations and gain experience outside the family firm is recommended for a positive succession experience (Cater et al., 2016; Danco, 1982; Nelton, 1986). Considering the claim above, by working for different organizations, successors are experiencing distinct organizational cultures hence, when assuming their role in the family business, they are bringing with them some aspects from the organizational cultures they experienced.

\subsubsection{Succession and Culture}

During the development period of the firm, the foundation of the business is being constructed at the same time as it is being established (Gersick et al., 1997). According to Gersick et al. (1997), the foundation of the firm is composed by three main parts one of which is organizational culture. It was also pointed out that organizational culture is based on values and assumptions that will determine the way the firm is managed, the way leaders make decisions, the style of leadership (ranging from autocratic to participatory), and most importantly, the culture will determine if employees are going to be loyal to the founder or loyal to the business itself. Cultural artifacts, such as the written mission of the firm, dress codes, physical aspects of the organization, and myths and tales about the founder are the representation of an organization's values; moreover, organizational culture. Gersick et al. (1997) concludes that the founder, through his behavior and attitude, is the ultimate representation of a company's values and beliefs. 
Dyer (1986) observed that, depending on the type of culture established in the company, the role played by the founder dramatically changes. For instance, the paternalistic culture is identified when leaders are responsible for all business decisions, the laissez-faire type of culture identified by Dyer is very similar; however, in the latter, employees tend to be seen as trustworthy. On the flip side, the participative culture, just like the name suggests, is identified when the decisions are made by the group, rather than the leader. Finally, the last of the four corporate cultures identified by Dyer is the professional culture, which is characterized by leaders that are not part of the family as well as impersonal employee relations.

The company culture, and the impact of family control in the business is noticed by employees of family firms (Gersick et al., 1997). According to Schein (1985) unsuccessful successions could be justified by the kind of structure of the firm, the stability, as well as the organizational culture. Dyer (1986) complements that culture represents the intersection between family and firm as well as the interference of the board, and this representation is crucial to succession. Taking the above into consideration, it has been concluded that the founder is the ultimate representation of the company's culture. On the other hand, if the successors have the opportunity to work for distinct organizations, they will bring different aspects from different organizational cultures to the business at the same time as trying to keep relevant aspects of the family firm culture.

In the remainder of this paper, an extension to the theoretical model for family business retailervendor strategic partnership developed by Smith et al. (2014) to include performance will be proposed. The existing model was successful in addressing the connection between relationship 
value, trust, commitment and family influence, which was measured by the F-PEC scale (Klein et al., 2005). Isolating culture and extending this model to include performance may permit the evaluation of the effects of family culture and relationship value on performance. 


\section{Model Development and Hypotheses}

The theoretical model is presented in Figure 2. As stated previously, the culture component from the F-PEC scale of family influence (Astrachan et al., 2002) is being used to evaluate the influence of family culture on the performance of family firms in retailer-vendor strategic partnerships. Five hypotheses, in the context of retailer-vendor strategic partnership, (solid paths in the model) tested by Smith et al. (2014) will be revalidated, and three new hypotheses, in the same context, (dotted paths in the model) to extend the model and bridge the gap between culture and performance will be proposed.

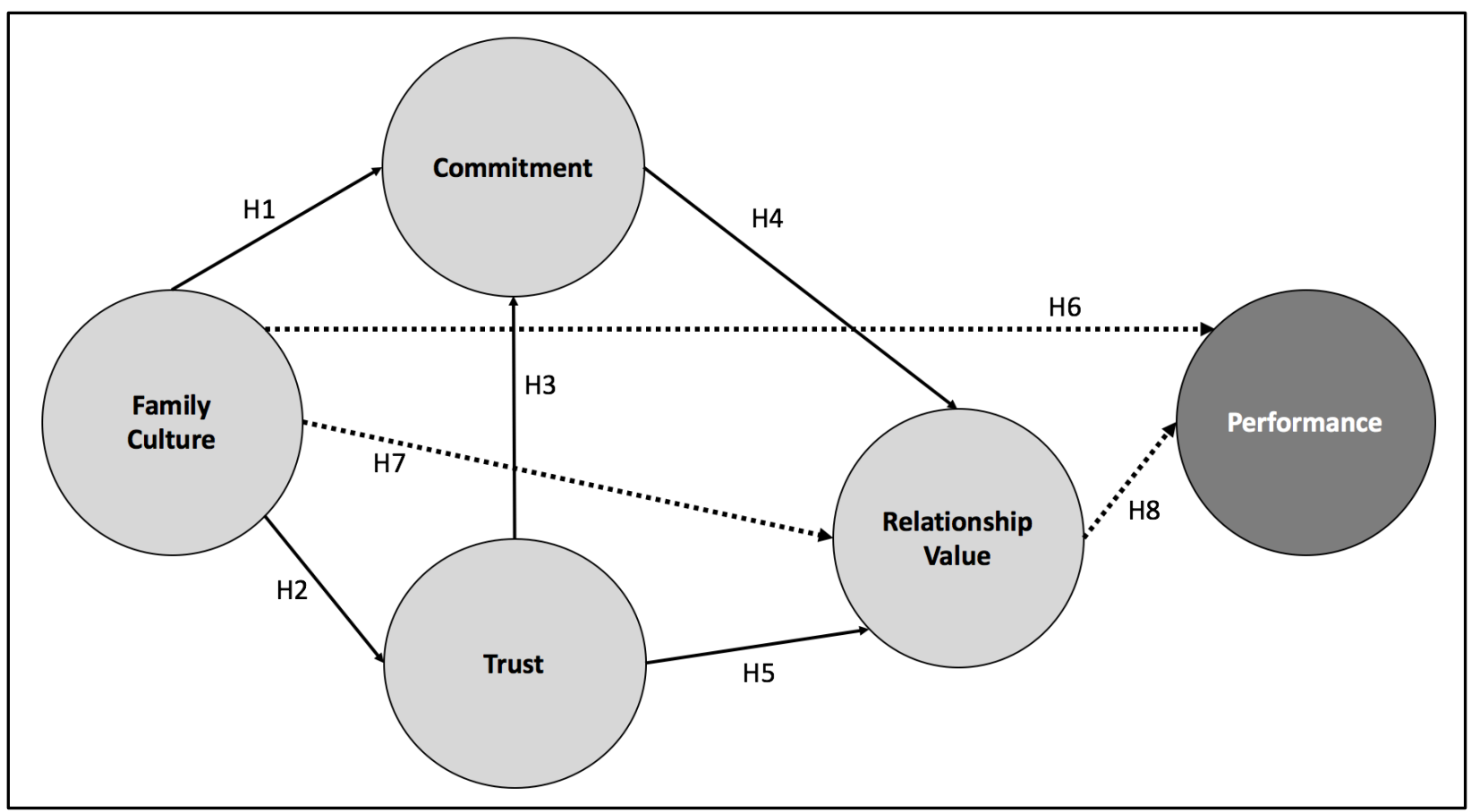

Figure 2: Theoretical Model for the Influence of Family Culture on Performance and Relationship Value in Retailer-Vendor Strategic Partnerships. 


\subsection{Prior Research in the Hypothesized Model}

\subsubsection{Family Culture}

In the model proposed by Morgan and Hunt (1994), the importance of shared values in relational exchange was evident by the fact that shared values were the unique antecedent to both commitment (supported at $\mathrm{p}<.01$ ) and trust (supported at $\mathrm{p}<.001$ ). Moreover, some scholars stated that values are the foundations of culture (e.g., Denison et al., 2004; Schein, 1985). In fact, Morgan and Hunt (1994) pointed out that the values measured by the family culture scales result from the same conceptual model as shared values. Morgan and Hunt (1994, p. 25) defined shared values as " . . the extent to which partners have beliefs in common about what behaviors, goals and policies are important or unimportant, appropriate or inappropriate, and right or wrong." According to Gallo (2000), business culture is a relevant characteristic of a family enterprise. Gallo (2000) holds the position that only after assumptions and values are shared between a family and a business, a firm can be considered a family business. However, in order to create values in an organization, time and effort must be invested. Klein (1991) complements that core values of individuals who work for an organization for more than 10 years and hold a strategic position, can be seen rooted in firm aspects, such as: internal policies, the way in which conflicts are solved, as well as, the degree of centralization vs. delegation. Nevertheless, measuring the overlap between firm and family values is a challenge, due to cross-generational transferability of values (Sarstedt, Ringle, Smith, Reams, \& Hair, 2014).

Taking into consideration that the interactions between family values and business are represented by family culture (Astrachan et al., 2002), it is concluded that family culture will positively influence both commitment and trust. Therefore, the following is proposed: 
$\mathrm{H}_{1}$ : There is a positive relationship between family culture and commitment in retailer-vendor strategic partnerships;

$\mathrm{H}_{2}$ : There is a positive relationship between family culture and trust in retailer-vendor strategic partnerships.

\subsubsection{Trust and Commitment}

A congruence between owners and employees' goals was defined by Davis et al. (2010) as stewardship. When employees identify themselves with the achievement of the organizational goals or even when they have interests beyond their personal and financial goals, they become stewards (Zahra et al., 2008). Davis et al. (2010) established a positive association between stewardship and trust for family employees, as well as non-family employees. In this study, since both relationship commitment and stewardship aim for the best interest of the business without opportunism, it is concluded that trust and commitment share the same goal. Taking into consideration the work of Morgan and Hunt (1994), this study proposes:

$\mathrm{H}_{3}$ - There is a positive relationship between trust and commitment in retailer-vendor strategic partnerships.

\subsubsection{Commitment and Relationship Value}

Regardless of the lack of agreement on how to measure value creation or relationship value in family business literature, a traditional approach to do so is to consider shareholder value, profitability, or even equity as value in family firms (Sindhuja, 2009). In fact, Pradhan and Ranajee (2012) stated that family relationship issues could affect performance in a family firm. A resource-based approach was used by other scholars, Barney (1991) and Sirmon and Hitt 
(2003) to investigate resources that are relevant to the family, such as human capital or governance structure. Chirico and Nordqvist (2010) used positive drivers, such as entrepreneurial orientation and knowledge, dynamic capabilities, and entrepreneurial performance, as well as negative drivers, such as family inertia and paternalism to develop a framework for transgenerational value creation.

According to Milton (2008), five years is the minimum period necessary to evaluate goals and investments of the business, as well as to involve future generations; hence, to develop long-term commitment. Through commitment, this future generation's leaders will, therefore, identify themselves with the corporate culture and demonstrate a voluntary behavior that may inspire employees to work more efficiently to achieve firm goals (Sharma \& Irving, 2005). Therefore, this study proposes:

$\mathrm{H}_{4}$ - There is a positive relationship between commitment and relationship value in retailervendor strategic partnerships.

\subsubsection{Trust and Relationship Value}

Steir (2001) pointed out that trust contributes to a more effective collaboration within employees of a firm. Furthermore, it helps in the development of an effective management process. Trust also contributes to the reduction of transaction costs in family business relationships (Steir, 2001). In this study, relationship value is explored as a source of competitive advantage, since it is defined as a set of trade-offs that takes into account accessible options and outcomes in the achievement of mutual goals (Smith et al., 2014). Therefore, in a relationship based on trust, better results could be expected (Milton, 2008); hence, it is proposed:

$\mathrm{H}_{5}$ - There is a positive relationship between trust and relationship value in retailer-vendor 
strategic partnerships.

\subsection{Extension of Model}

\subsubsection{Family Culture and Performance}

Barney (1986) stated that despite the lack of agreement on the definition of organizational culture, there is a common belief that organizational culture influences financial performance. Barney (1986) proposed as well three conditions that must be accomplished in order to provide sustained superior performance. The first one is that the culture must encourage a firm to be more effective, by increasing sales, reducing costs, or even obtaining high margins. If superior financial performance is an economic concept, culture therefore, affects performance. The second condition is related to how rare the culture is. In other words, the culture must be different from other organizations cultures. Finally, the third condition is related to how difficult it is to imitate this culture. In other words, if the culture of the company is difficult to copy, the organization that developed this culture will have some advantage compared to the organizations that are trying to imitate them.

The Denison Organizational Culture Model (Denison et al., 2004) described a concept of organizational culture that is related to company performance. In fact, the results generated by Denison's culture model, could provide information to managers to increase the strengths and reduce weaknesses of the company, in other words, influence performance. Furthermore, Hollander and Bukowitz (1990) concluded that there is no distinction between family culture and organizational culture. The forms of behavior that are institutionalized by the culture of the family will influence the organizational culture as well. Hence, this study proposes: 
$\mathrm{H}_{6}$ - There is a positive relationship between family culture and performance in retailer-vendor strategic partnerships.

\subsubsection{Family Culture and Relationship Value}

As was previously observed, Denison et al. (2004) stated that values are the foundation of culture. Hence, the core values established by the family will influence the type of culture developed in the family business. Smith et al. (2014) added that relationship value is a set of trade-offs that occurs aiming mutual goals. Relationship value is, therefore, a source of competitive advantage (Vázquez et al., 2005).

The positive effect of family culture on share values was evident in Morgan and Hunt's (1994) study. The influence of culture on employee behavior was also observed by Sharma and Irving (2005, p. 26), who concluded that leaders could demonstrate "discretionary behaviors", and that this behavior could inspire employees to work toward superior goals. Therefore, since culture is a set of beliefs developed by a group as well as values that are shared by the same group, which represents the intersection of a firm's and a family's values (Top et al., 2013), it is proposed: $\mathrm{H}_{7}$ - There is a positive relationship between family culture and relationship value in retailervendor strategic partnerships.

\subsubsection{Relationship Value and Performance}

According to Astrachan et al. (2002), the amount of impact that a family has on a business is highly associated with the extent of commitment between the family and the business itself. The keys to orient a commitment to the business are family values and what a family establishes as important or crucial (Carlock \& Ward, 2001). When companies develop a cooperation process, they are not only establishing a partnership but also building new skills, saving resources, 
sharing risks as well as drawing new investments (Hutt, Stafford, Walker, \& Reinge, 2000). Relationship value is therefore the outcome of the cooperation process mentioned above. The benefits generated by this association range from profit and sales volume to innovation and access to new markets (Ryssel, Ritte, \& Gemunden, 2004). Taking into consideration that relationship value was previously correlated with greater profitable outcomes, such as sales performance (Huntley, 2006) as well as purchasing efficiency (Han, Wilson, \& Dant, 1993), this study proposes:

$\mathrm{H}_{8}$ - There is a positive relationship between relationship value and performance in retailervendor strategic partnerships. 


\section{Research Methodology}

\subsection{Epistemological Orientation}

While ontology is mainly concerned with the nature of reality (Hudson \& Ozanne, 1988), epistemology is focused on the relationship between the researcher and the reality (Carson, Gilmore, Perry, \& Gronhaug, 2001). Depending on the orientation adopted by the researcher, it will influence the research method as well as the way data will be gathered and analyzed (Bryman, 2001).

This work operates from the positivism ontological orientation, which considers that the world is external (Carson et al., 2001), and regardless of beliefs and values, any phenomenon or social situation could be acknowledged by a single objective reality (Hudson \& Ozanne, 1988). Therefore, after identifying the research topic, it is evident that a structural and controlled approach to conduct the project is being used. Neutrality will be maintained by avoiding interaction with respondents, which was stated by Carson (2001) as a main concern of the positivist ontological perspective.

The implications of a positivist orientation include remaining independent of observations by maintaining an objective standpoint rather than influencing results with personal bias. Besides those basic implications, it is relevant to mention that the eight proposed hypotheses are going to be validated according to objective results. All in all, a phenomenon is being measured quantitatively. The culture sub-scale from the F-PEC scale applied in the study is an example of such an approach. 
Regarding the positivist orientation of this research, it can be argued that it is operating from an epistemological functionalist perspective, rather than a radical structuralist one. Functionalists

define society as an interconnected system that works together to generate social equilibrium, in other words, balance for the whole (Mooney, Knox, \& Schacht, 2007). Examples of this contribution from social mechanisms to society are families, education, politics, economics, and religion. In the case of families, it provides a context for socialization and development. The sense of development is also observed in the context of education, which is an example of a way to transmit knowledge. Scholars such as Barney (1986), Denison et al. (2004), and Hollander and Bukowitz (1990), who have been referenced throughout, proposed that family nurtures culture, and culture influences performance. Therefore, by relying on this proposal as well as using a structured scale, such as the culture component from the F-PEC scale, to investigate the influence of culture in performance, the notion that there are interconnected mechanisms operating in society is ratified.

\subsection{Measurement of Culture}

Family business research presents research challenges, such as response rates, company size, and the amount of data that is available for researchers. Bird et al. (2002) mentioned that the availability of data, especially substantial historical data, is minimal for family business. The opposite is very true for non-family organizations, for which historical data can be easily found and studied. Stamm \& Lubinski (2011) highlighted that the response rate in family business is lower than the rates of response noted on non-family organizations.

There is a discussion among scholars regarding the recommended method to explore culture on organizations. On the one hand, a considerable number of scholars hold the opinion that 
ethnographic methods are the appropriate way to approach it, due to the necessity of providing a description of the culture itself (Wilson et al., 2014). However, on the other hand, another group of scholars believe that statistical methods are more recommended in order to provide better theory and insights, hence, advance the field of family business (Zahra \& Sharma, 2004). Surveys are often used to investigate the climate within the organization (Joyce \& Slocum, 1984), while ethnographic studies are most commonly used to study organizational culture, due to the fact that culture is not explicit. The critique about surveys as a tool to investigate culture is related to a questionnaire as a product of culture itself, therefore it is culture biased. Deshpande (1989) stated that culture allows for and should be explored by both methods - ethnographic and statistical survey methods.

According to Deshpande (1989), culture as a variable is a viable perspective; hence, culture as a variable exogenous to the firm, in other words, something that was developed from external factors. In that case culture plays a main role in the organization by influencing and reinforcing the main values and beliefs of the firm. Examples of this approach are studies that are aiming to investigate job satisfaction or even culture influence on effectiveness. Some studies comparing American and Japanese culture and how those cultures differentiate the company outcome is a good example of this approach (Pascale \& Athos, 1981).

A different approach is to consider culture as an internal cause or endogenous to the organization, in other words, as an independent variable. In this case, culture is also a set of values and beliefs; however, those values and beliefs are developed within the organization. This approach is related to contingency methods (Deshpande \& Webster, 1989). In these cases, culture influences performance by influencing employee commitment and identification with the 
core values and beliefs. Smircich (1983, p. 345) stated that culture "can be used to build organizational commitment, convey a philosophy of management, rationalize and legitimate activity, motivate personal, and facilitate socialization".

In order to provide a description of the effect that culture has on the performance of family firms, it is argued that the deductive research method is more adequate. According to Blaikie (2010), one of the objectives of the deductive method is to propose a theory, which can be validated by testing hypothesis, to describe the association between two constructs.

\subsection{Partial Least Squares Structural Equation Modeling - PLS-SEM}

The recognition that undeveloped techniques were, by far, the most popular method used by family business researchers was stated by Wortman (1994). A review of 148 family business research articles concluded in 2002 (Bird et al., 2002) ratifies this recognition, since 113 (76.35\%) of the studies relied on descriptive and bivariate analyses or did not use any statistical analysis to draw its conclusions. However, according to Wilson et al. (2014), associated with the evolution that family business research is facing, substantial changes in the statistical methods are being presented in order to deal with gradually more complex models.

Covariance-based SEM (CB-SEM) and PLS-SEM are two approaches to estimate relationships in a structural model. CB-SEM is indicated when the objective of the study is to test, confirm, or even compare theories. In this case, additional specification is required by error terms, the model must present non-recursive relationships, and a goodness-of-fit measure must be provided in order to advance with the research (Hair, Hult, Ringle, \& Sarstedt, 2017). However, when the primary objective of the model is to predict and explain a specific construct, PLS-SEM is more suitable (Rigdon, 2012). Additionally, when formative constructs are considered in the model, 
the data distribution is not normal, or even the sample size is small, PLS-SEM is recommended (Hair et al., 2017).

As highlighted above, structural equation modeling (SEM) is a statistical modeling technique that enables researchers to use constructs (unobservable variables measured indirectly by indicator variables) in their models (Hair et al., 2017). Sarstedt et al. (2014) states that PLS-SEM not only considers constructs, but also enables researchers to review and classify constructs as formative or reflective. By using partial least squares structural equation modeling (PLS-SEM), researchers are also able to estimate complex models with a reduced number of observations. According to Sarstedt et al. (2014) family business researchers could use PLS-SEM to deal with the challenges of working with high complexity theories and cause-effect models. Moreover, due to the fact that the PLS-SEM allows deeper analysis of the cause-effect relationships, researchers could analyze the mediating relationships in the PLS path model, increasing their knowledge of the relationships between the constructs. Henseler et al. (2014) pointed out the usefulness of PLS-SEM in developing and testing theories in family business research. Furthermore, extensions and complementary analysis techniques will increase PLS-SEM use by researchers. With those extensions, researchers will incorporate more complex model relationships and deal with data insufficiencies, that were impossible to work with using previous statistical techniques. The conclusion reached by Sarstedt et al. (2014) suggests that PLS-SEM incorporates methods that provide researchers with the necessary research tools and that family business researchers should exploit such strides in existing and future models. Recognizing that this project presents the aforementioned characteristics as well as the relevance of the features discussed above, PLSSEM is the approach adopted in this context. 


\subsection{Sample and Data Collection}

In light of the fact that family firms are a crucial component to the development of the US economy, which relies heavily on retailing (Smith, 2016), data has been collected in the United States. According to PwC (2014), in 2012, 23.4\% of total national employment and $16 \%$ of Gross Domestic Product (GDP) were generated by the US retail industry. From a sales perspective, the subsectors responsible for higher performance are general merchandise, apparel, furniture, and specialty items (Plunkett, 2013). Only 3\% of the firms in the US retail industry have more than 500 employees, which indicates that there is a very polarized industry to deal with. According to the United States Census Bureau (2012), the estimative of the percentage of family firms in the retail industry was $24.5 \%$. In 2014, consultants from EY and Kennesaw State University's Cox Family Enterprise (2015) conducted a survey with the 2,400 largest family firms worldwide. When the responses from the US were analyzed separately, the results clearly indicated the importance of the retail industry in the US, since $26 \%$ of the respondents cited the retail industry as the most important industry in the United States.

Family business is a unique type of organization; therefore, a singular field of study. Family firms have to deal with inter-personal dynamics that are, most of the time, unusual to non-family organizations (Astrachan et al., 2002). This research will investigate family culture in the context of retailer-vendor strategic partnerships. Through the lens of these important business relationships, culture and its impact on performance will be examined in addition to culture interrelationship with other variables on performance.

Data was collected from a database generated from a questionnaire that was applied to previous research done by Smith et al. (2014). The online questionnaire was applied in May/June 2012, 
and all respondents of that survey were either owners or senior executives responsible for managing a strategic partnership of family firms in the U.S. retail and service sector. Taking into consideration its specificity, Smith et al. (2014) indicated that a marketing research firm was hired to guarantee that the correct target was going to be selected. Major strategic partner, the reference used by the respondents to answer the survey, was defined as "their most important vendor or supplier with respect to achieving a higher level of competitiveness over the next 3-5 years" (Smith et al., 2014, p. 258). Screening questions were used to ensure the right participants were answering the survey. Data was cleansed by using the following techniques. Filter questions were used and respondents who didn't recognize these questions were eliminated from the sample. Respondents who took less than five minutes to answer the questionnaire as well as those who straight-lined answers were also eliminated from the sample. A common method bias was avoided in the questionnaire by using different scales, as well as selecting, through a randomization process, the statements presented in the questions (Dillman, Smyth, \& Christian, 2009; Podsakoff, MacKenzie, Podsakoff, \& Lee, 2003). Appendix 7.4 - data construct descriptions in alphabetical order, shows the constructs and variables and their origins that were used in this research.

\subsubsection{Sample Size X Theoretical Model}

After the process of cleaning the data, which was conducted by Smith et al. (2014), the final sample was composed of 119 respondents. The first test that was implemented to check the robustness of the sample is the 10 times-rule, proposed by Barclay et al. (1995). According to this rule, in order to be qualified as adequate, a sample size should fulfill at least one of two basic requirements. The first one states that the sample size should be larger than 10 times the largest 
number of formative items to measure a single construct. In the model proposed in this research, the largest number of formative items is 4 ; therefore, according to this requirement a sample larger than 40 respondents is required. The second requirement states that the sample size should be larger than 10 times the largest number of structural paths pointed out at a single construct. In the proposed model, the largest number of structural paths directed to a single construct is 3 ; hence, in this case, a sample larger than 30 respondents is required.

Moreover, according to Hair et al. (2017), as PLS-SEM is built upon OLS regression characteristics, Cohen's (1992) rules of thumb should be adopted to determine whether the sample size in this project is adequate or not. These rules of thumb indicate that measurement model quality could be identified by the number of independent variables, which is the maximum number of arrows pointing at a same construct. In Table 3, a sample size recommendation is presented in PLS-SEM for a statistical power of $80 \%$. Using this table as a reference, the maximum number of arrows pointing at a construct in this model is 7 (relationship value); therefore, considering the sample of 119 respondents, it can be concluded that the minimum sample requirements to test the model have been met, as 73 observations are required to detect R2 values of around 0.25 at a significance level of $1 \%$ and a power level of $80 \%$ (Cohen, 1992), and the sample size used in this study is considerably larger than 73. 


\begin{tabular}{|c|c|c|c|c|c|c|c|c|c|c|c|c|}
\hline \multirow{4}{*}{\begin{tabular}{|l} 
Maximum \\
Number of \\
Arrows \\
Pointing at a \\
Construct \\
(Number of \\
Independent \\
Variables) \\
\end{tabular}} & \multicolumn{12}{|c|}{ Significance Level } \\
\hline & \multicolumn{4}{|c|}{$10 \%$} & \multicolumn{4}{|c|}{$5 \%$} & \multicolumn{4}{|c|}{$1 \%$} \\
\hline & \multicolumn{4}{|c|}{ Minimum $\mathbf{R}^{2}$} & \multicolumn{4}{|c|}{ Minimum $\mathbf{R}^{2}$} & \multicolumn{4}{|c|}{ Minimum $\mathbf{R}^{2}$} \\
\hline & 0.10 & 0.25 & 0.50 & 0.75 & 0.10 & 0.25 & 0.50 & 0.75 & 0.10 & 0.25 & 0.50 & 0.75 \\
\hline 2 & 72 & 26 & 11 & 7 & 90 & 33 & 14 & 8 & 130 & 47 & 19 & 10 \\
\hline 3 & 83 & 30 & 13 & 8 & 103 & 37 & 16 & 9 & 145 & 53 & 22 & 12 \\
\hline 4 & 92 & 34 & 15 & 9 & 113 & 41 & 18 & 11 & 158 & 58 & 24 & 14 \\
\hline 5 & 99 & 37 & 17 & 10 & 122 & 45 & 20 & 12 & 179 & 66 & 28 & 16 \\
\hline 6 & 106 & 40 & 18 & 12 & 130 & 48 & 21 & 13 & 188 & 69 & 30 & 18 \\
\hline 7 & 112 & 42 & 20 & 13 & 137 & 51 & 23 & 14 & 196 & 73 & 32 & 19 \\
\hline 8 & 118 & 45 & 21 & 14 & 144 & 54 & 24 & 15 & 204 & 76 & 34 & 20 \\
\hline
\end{tabular}

Table 3: Sample size recommendation in PLS-SEM for a statistical power of $80 \%$ (Cohen, 1992).

Another aspect that influenced the sample size that is important to highlight is how difficult it is to identify qualified participants who manage retailer-vendor strategic partnerships. Even though a research company was hired to select participants, this target group is scarce and very difficult to reach. According to Smith (2011), managers of strategic partnerships are very difficult to find not only because they work in different areas such as marketing, finance, logistics, merchandising, procurement, and human resources; but also because they hold different positions in the firm, for example, presidents, directors, CEOs, CFOs, buyers, merchandising managers, promotional managers, and many others. Taking all of the above into consideration, confidence is found in the robustness of the sample from which meaningful data can be drawn.

\subsection{Data Analysis Method}

Before defining the appropriate method for analyzing the data, the Kolmogorov-Smirnov (K-S) and Shapiro-Wilks $\left(\right.$ Norus $^{\wedge}$ is, 2009) tests was applied on all indicator variables (with significance at the $\mathrm{p}=0.000$ level) used in the model. The use of partial least squares structural 
equation modeling (PLS-SEM) (Hair et al., 2017; Hair, Ringle, \& Sarstedt, 2011b) was initially proposed because the distribution of the data was not normal. Additionally, the PLS-SEM method allows for reflective, as well as formative, constructs more effectively than other methods considered, such as covariance-based structural equation modeling (CB-SEM) (Hair et al., 2017; Hair et al., 2011b).

\subsubsection{Reflective Constructs}

Reflective constructs are based on a theory that proposes that a measure could represent the effects of an underlying construct (Nunnally \& Bernstein, 1994). Therefore, the phenomenon orientation is from the construct to its measures. Taking into consideration that the relationship orientation is from the construct to its measures, it is implicit that if the evaluation of the latent attribute (the construct) changes, all indicators will change simultaneously. Researchers typically refer to a set of reflective measures as a scale (Hair et al., 2017).

In light of the guidelines proposed by Hair et al. (2017, p. 52), the first reflective construct is family culture, which is derived from the F-PEC scale (Astrachan et al., 2002). The F-PEC scale or index was developed by Astrachan et al. (2002). According to their study, in order to analyze family influence in a business, three dimensions must be considered: power, experience, and culture. The F-PEC index is, therefore composed of these three dimensions or subscales. By using the F-PEC index, researchers could analyze family participation as well as its impact on performance among different businesses. The main themes considered as the foundation of the FPEC index were the outcome of an in-depth content analysis of different definitions of family business performed by Astrachan et al. (2002). Hence, the scales of the F-PEC index could be used to measure family influence in an organization, which is the objective of this study. 
The psychometric properties of the F-PEC index were disclosed by Astrachan et al. (2002, p. 52) as a multi-level process. The process consists of establishing consistency of items that compose the F-PEC subscales and overall scale by analyzing item (Crombach's alpha) coefficients. Items in relation to power, experience, and culture - the three subscales - were then checked for unidimensionality as well as reliability. In order to guarantee that each item was reacting to its respective underlying concept, congeneric measurement models were created. Finally, goodness of fit was then assessed to evaluate the level of accuracy between the scores from data that was being observed and the results from an estimated model. The outcome should provide the reliability as well as how satisfactory items were to accommodate the hypothesized model.

In this research the use of the culture subscale from the F-PEC scale (Astrachan et al., 2002), will provide an understanding of how families gain, lose, or maintain influence, in light of business performance.

The influence of family culture, the first reflective construct in this study, was recognized by Fletcher et al. (2012) but other authors acknowledged this influence in more detail: as a source to define investments (Sharma \& Manikutty, 2005), a driver of performance (Corbetta \& Salvato, 2004), to determine succession (Dyer, 1988), and also as a source of competitive advantage (Carr \& Bateman, 2010).

Taking into consideration Hair et al. (2017, p. 52) guidelines, commitment is also derived from a previously tested scale (Morgan \& Hunt, 1994); and the indicators represents the consequences of commitment. For example, commitment influences performance (Smith et al., 2014). Another source of competitive advantage is trust (Chami, 2001) as it increases profitability and 
strengthens business relationships (Sundaramurthy, 2008). As a result, both, commitment and trust are influencing performance, which means that performance is a consequence of commitment, trust and family culture.

Performance is the last reflective construct within which a strategic management perspective, that was proposed by Venkatraman e Ramanuja (1986), is adopted in order to measure performance. Additional support can be found in Hult's et al. (2003) perspective, which defined performance as the achievement of goals, increase of sales and market share, and also the accomplishment of strategic objectives. It is assumed, in fact, that those effects (goals, sales, market share, and strategic objectives) are the consequence of performance, in other words, the indicators used in this study.

\subsubsection{Formative Constructs}

According to Diamantopoulos et al. (2001), scholars should determine the use of either a reflective or a formative construct, mainly based on theoretical evidence regarding the causal orientation between the construct and its respective indicators. Marketing research is evolving; however, it is primarily focused on the use of scales, which implies that the items used in a scale are considered reflective (e.g. DeVellis, 1991; Spector, 1992). A formative or causal indicator is an alternative measurement approach and it is based on an index (Bollen \& Lennox, 1991). Hence, formative indicators are not the reflection or consequence of a variable, rather the "cause".

Formative constructs rely on the assumption that indicators are forming the construct by means of linear combinations (Diamantopoulos \& Winklhofer, 2001). Those indicators could be either composite or causal. Composite indicators form the constructs, and causal, as the name suggests, 
are the construct's cause. Composite indicators do not assume that a certain construct can be fully measured using a set of indicators and an error term, rather, composite indicators view measurement as an approximation of a certain theoretical concept. According to Hair et al. (2017) the PLS-SEM algorithm is fully based on the concept of composite indicators. Thus, since the PLS-SEM method is used in this work, formative indicators are referred to when denoting composite indicators. An important aspect of formative indicators is that each indicator captures a different aspect of the construct; therefore, formative indicators are not interchangeable. This particular aspect of formative indicators is highlighted by Bollen and Lennox (1991, p. 308) who argue that "omitting an indicator is omitting a part of the construct".

Relationship value, the only formative construct in the proposed model, was classified as a formative construct due to the fact that relationship value is formed by a set of trade-offs (e.g. Smith et al., 2014; Ulaga \& Eggert, 2006). Moreover, mutual goals, competitiveness, and profitability, the sources of value creation in the business relationship (Vázquez et al., 2005), are the composite indicators that form relationship value. According to Diamantopoulos et al. (2001), the first concern that researchers need to address when dealing with formative constructs is to establish the scope of the latent variable. In other words, the amount of content that researchers expect the index to cover.

Taking into consideration that a set of trade-offs "causes" relationship value (e.g. Smith et al., 2014; Ulaga \& Eggert, 2006; Vázquez et al., 2005), the scope of relationship value was divided into three main subjects: goal congruence, trade-offs, and competitiveness. Two questions for each subject were included in the questionnaire. RELV1 and RELV2 covered goal congruence, RELV3 and RELV4 addressed replacement or trade-offs, and RELV5 and RELV6 focused on 
competitiveness. As will be discussed in further detail throughout section 5, during the process of analysis, RELV1 and RELV4 were removed from the model. However, since two questions with the same nomological net were used for each part of the scope of the construct, all aspects of relationship value are being captured. Hence, capturing its essence. 


\section{Data Analysis and Results}

There is a considerable number of software available in the market in order to run the PLS-SEM algorithm. A popular example is PLS-Graph (Chin, 2003), which was the first software in the field and could be considered a graphical interface as well as more user friendly than LVPLS, which was developed by Lohmoller (1987). However, neither PLS-Graph nor LVPLS have been updated recently. More recent examples of software available to work with PLS-SEM algorithm are XLSTAT’s PLSPM package, Adanco (Henseler \& Dijkstra, 2015); PLS-GUI (Hubona, 2015); WarpPLS (Kock, 2015); and SmartPLS (Ringle, Wende, \& Becker, 2015).

SmartPLS was used to analyze the data previously collected by Smith et al. (2014). The justification of the choice of SmartPLS is based on two main reasons. First, SmartPLS is the most up to date software, and second it is continually being improved. The study by Smith et al. (2014) used Smart PLS 2 (Ringle, Wende, \& Will, 2005) to analyze the data. Smart PLS 3 (Ringle et al., 2015) has new functionalities and will be used in this research.

\subsection{Assessment of Reflective Measurement Models}

In order to assess the quality of the results, a set of rules that was proposed by Hair et al. (2017) was implemented. Internal consistency reliability, convergent validity, and discriminant validity methods were undertaken for the reflective constructs. Internal consistency reliability was evaluated by the intercorrelations of the observed indicator variables. Family culture, commitment, trust, and performance, exceed 0.70 on Cronbach's Alpha analysis. Performance indicated .95 for composite reliability, which suggests that performance scales could need additional testing due to a possible semantic resemblance (Hair et al., 2017). The relationship between the indicators and their respective constructs was verified by the outer loading relevance 
test, which is provided in Appendix 7.1 - Reflective Constructs Outer Loadings. During the indicator reliability test, variable FC12 (deciding to be involved with the family business has a positive influence on my life) was removed from the model, due to a 0.666 result, which indicates that this indicator was not distinct from others. The rule of thumb indicates that outer loadings must present 0.708 or higher in indicator reliability (Hair et al., 2017). The average variance extracted (AVE) exceeded 0.65 for all the reflective constructs in the model. A minimum of 0.50 is required to confirm convergent validity. Discriminant validity was verified by a three-method sequence: cross loadings, Fornell-Larcker criterion, and heterotrait-monotrait ratio (HTMT). All family culture's outer loadings on culture were greater than any of its cross-loadings on other constructs. The same result was verified for commitment, trust, and performance, which indicates a successful result for discriminant validity. Reflective constructs cross loadings results are presented in Appendix 7.2. The second method applied was the Fornell-Larcker criterion. The square root of all reflective constructs' AVE was larger than its correlation with other constructs, thus indicating discriminant validity. The final method to test discriminant validity was to examine the HTMT of the correlations. Hair et al. (2017) advises that a confidence interval which contains the number 1 indicates a lack of discriminant validity. After conducting the bootstrapping, it was found that the value 1 was outside the interval's range, suggesting that these particular constructs were empirically distinct. 


\begin{tabular}{|c|c|c|c|c|c|c|c|}
\hline & RESULTS SU & MARY FOR & ELECTIVE ME & REMEN & ODELS & & \\
\hline \multirow{3}{*}{$\begin{array}{c}\text { Latent } \\
\text { Variable }\end{array}$} & \multirow{3}{*}{ Indicators } & \multicolumn{3}{|c|}{ Convergent Validity } & \multicolumn{2}{|c|}{$\begin{array}{c}\text { Internal Consistency } \\
\text { Reliability }\end{array}$} & \multirow[t]{2}{*}{$\begin{array}{l}\text { Discriminant } \\
\text { Validity }\end{array}$} \\
\hline & & Loadings & $\begin{array}{l}\text { Indicator } \\
\text { Reliability }\end{array}$ & AVE & $\begin{array}{r}\text { Composite } \\
\text { Reliability }\end{array}$ & $\begin{array}{l}\text { Cronbach' } \\
\text { s Alpha }\end{array}$ & \\
\hline & & $>0.70$ & $>0.50$ & $>0.50$ & $0.60-0.90$ & $0.60-0.90$ & $\begin{array}{c}\text { HTMT } \\
\text { confidence } \\
\text { interval does } \\
\text { not include } 1 \\
\end{array}$ \\
\hline \multirow{14}{*}{ Family Culture } & $\mathrm{FC1}$ & 0.784 & & \multirow{14}{*}{0.648} & \multirow{14}{*}{0.96} & \multirow{14}{*}{0.955} & \multirow{14}{*}{ Yes } \\
\hline & FC2 & 0.807 & & & & & \\
\hline & FC3 & 0.874 & & & & & \\
\hline & FC4 & 0.838 & & & & & \\
\hline & FC5 & 0.733 & & & & & \\
\hline & FC6 & 0.849 & & & & & \\
\hline & $\mathrm{FC7}$ & 0.761 & & & & & \\
\hline & FC8 & 0.8 & & & & & \\
\hline & FC9 & 0.809 & & & & & \\
\hline & FC10 & 0.863 & & & & & \\
\hline & FC11 & 0.715 & & & & & \\
\hline & FC12 & 0.666 & & & & & \\
\hline & $\mathrm{FC} 13$ & 0.871 & & & & & \\
\hline & FC14 & 0.744 & & & & & \\
\hline \multirow{7}{*}{ Commitment } & $\mathrm{C} 1$ & 0.931 & & \multirow{7}{*}{0.752} & \multirow{7}{*}{0.955} & \multirow{7}{*}{0.944} & \multirow{7}{*}{ Yes } \\
\hline & $\mathrm{C} 2$ & 0.911 & & & & & \\
\hline & $\mathrm{C} 3$ & 0.892 & & & & & \\
\hline & C4 & 0.796 & & & & & \\
\hline & C5 & 0.891 & & & & & \\
\hline & C6 & 0.89 & & & & & \\
\hline & $\mathrm{C7}$ & 0.744 & & & & & \\
\hline \multirow{6}{*}{ Trust } & $\mathrm{T} 1$ & 0.942 & & \multirow{6}{*}{0.843} & \multirow{6}{*}{0.97} & \multirow{6}{*}{0.963} & \multirow{6}{*}{ Yes } \\
\hline & $\mathrm{T} 2$ & 0.944 & & & & & \\
\hline & $\mathrm{T} 3$ & 0.86 & & & & & \\
\hline & $\mathrm{T} 4$ & 0.927 & & & & & \\
\hline & T5 & 0.943 & & & & & \\
\hline & T6 & 0.891 & & & & & \\
\hline \multirow{7}{*}{ Performance } & P1 & 0.861 & & \multirow{7}{*}{0.792} & \multirow{7}{*}{0.964} & \multirow{7}{*}{0.956} & \multirow{7}{*}{ Yes } \\
\hline & P2 & 0.919 & & & & & \\
\hline & P3 & 0.906 & & & & & \\
\hline & P4 & 0.908 & & & & & \\
\hline & P5 & 0.923 & & & & & \\
\hline & P6 & 0.853 & & & & & \\
\hline & P7 & 0.854 & & & & & \\
\hline
\end{tabular}

Table 4: Results summary for reflective measurement models

\subsection{Assessment of Formative Measurement Models}

Assessment of convergent validity, collinearity, as well as significance and relevance are the processes recommended by Hair et al. (2017) to validate formative indicators. Convergent validity was verified by a redundancy analysis on relationship value (REV), the only formative construct present in the model. The path between REV formative (RELV1, RELV2, RELV3, RELV4) and REV reflexive (RELV5, RELV6) was 0.788 , clearly inside the (0.70 to 0.80$)$ interval suggested by Hair et al. (2017) as a rule of thumb. A variance inflation factor (VIF) 
analysis was conducted in order to identify the degree to which the standard error has been increased due to the presence of collinearity. All variables in relationship value presented VIF values below 5, indicating no collinearity issues. VIF results are presented in Appendix 7.3. In order to test significance and relevance a bootstrapping procedure was performed. The bootstrapping settings were adjusted with 5,000 bootstrap samples, 300 observations, and the "no sign change" option. Four indicators (RELV2, RELV3, RELV4, and RELV6) displayed values superior than 0.05 , indicating a lack of significant outer weight at a significance level of $5 \%$. Absolute contribution of each of these indicators was evaluated by the outer loading result. Hair et al. (2017) recommend that indicators with outer loading values above 0.50 must remain in the model, even though they are not significant, due to their absolute contribution. Three indicators, RELV2, RELV3, and RELV6 presented values above 0.50; therefore, these constructs were maintained in the model. Due to its lack of significance as well as its absolute contribution, RELV4 was deleted from the model. A summary of the analysis of formative measurement models is found in the table below.

\begin{tabular}{|c|c|c|c|c|c|c|}
\hline \multicolumn{2}{|c|}{ Formative Constructs Outer Weights Significance Testing Results } \\
\hline $\begin{array}{c}\text { Formative } \\
\text { Constructs }\end{array}$ & $\begin{array}{c}\text { Formative } \\
\text { Indicators }\end{array}$ & $\begin{array}{c}\text { Outer weights } \\
\text { (Outer Loadings) }\end{array}$ & $t$ Value & $p$ Value & $\begin{array}{c}\text { 95\% Bca Confidence } \\
\text { Interval }\end{array}$ & Significance $(p<0.05)$ ? \\
\hline \multirow{5}{*}{$\begin{array}{c}\text { Relationship } \\
\text { Value }\end{array}$} & RELV1 & $0.542(0.86)$ & 4.206 & 0.000 & {$[0.280,0.752]$} & Yes \\
\cline { 2 - 7 } & RELV2 & $-0.007(0.689)$ & 0.041 & 0.967 & {$[-0.292,0.391]$} & No \\
\cline { 2 - 8 } & RELV3 & $0.181(0.782)$ & 1.196 & 0.232 & {$[-0.099,0.475]$} & No \\
\cline { 2 - 7 } & RELV5 & $0.087(0.259)$ & 0.894 & 0.371 & {$[-0.130,0.251]$} & No \\
\cline { 2 - 7 } & RELV6 & $-0.034(0.698)$ & 0.229 & 0.819 & {$[-0.319,0.264]$} & Yes \\
\hline
\end{tabular}

Table 5: Results summary for formative measurement models 


\subsection{Assessment of the Structural Model}

In order to evaluate the model's predictive capabilities as well as the relationship between constructs, an assessment of the structural model was conducted. Hair et al. (2017) indicates that the first step is to confirm that the model does not present any collinearity issues. For each predictor construct in the model (family culture, trust, commitment, and relationship value), a VIF analysis was undertaken.

According to Allison (2012), regardless the agreement among scholars on the VIF lower bound value of 1 to constitute a multicollinearity problem, there is no such agreement on the upper bound value. On the one hand, Allison (2012) suggests that a VIF upper bound value of 2.5 could possibly indicate a problem. On the other hand, Hair et al. (2017) proposes the threshold of 5 to indicate a problem. In a review of 8 studies that applied formative measurement models, Richer et al. (2016) noticed that Hair et al. (2011a) was cited as the guideline to address multicollinearity issues, supporting Hair et al. relevance. As the largest VIF value in the proposed model is 3.249 , this value is positioned slightly above Allison's suggestion, but quite below Hair's et al. threshold. Taking this result into consideration as well as the other VIFs values, located between the interval of 1 and 5 , this model does not present collinearity problems.

\begin{tabular}{|l|c|c|c|c|c|}
\hline \multicolumn{5}{|c|}{ Collinearity Analysis (VIFs) } \\
\hline & Commitment & Family Culture & Performance & $\begin{array}{c}\text { Relationship } \\
\text { Value }\end{array}$ & Trust \\
\hline Commitment & & & & 3.072 & \\
\hline Family Culture & 1.069 & & 1.014 & 1.108 & 1 \\
\hline Performance & & & 1.014 & & \\
\hline Relationship Value & & & 3.249 & \\
\hline Trust & 1.069 & & &
\end{tabular}

Table 6: Results for VIF analysis (collinearity issues) 
The second step is to analyze the hypothesis tests, $\mathrm{R}^{2}$ values, and predictive relevance, in order to evaluate the underlying theory of the model. An illustration of the path coefficients analysis is provided in Figure 3. Hypothesis 1 predicts a positive relationship between family culture and commitment and was rejected at $\mathrm{p}=0.115$. Hypothesis 2 predicts a positive relationship between family culture and trust and was accepted at $p=0.043$, which confirms the same results as the Smith et al. (2014) article. The positive relationship between commitment and trust proposed by Morgan \& Hunt (1994) is ratified by the acceptance of Hypothesis 3 at $p=0.00$. Hypothesis 4 predicted a positive relationship between commitment and relationship value and was accepted at $\mathrm{p}=0.001$; however, Hypothesis 5 was rejected at $\mathrm{p}=0.904$, indicating the lack of a positive relationship between trust and relationship value. Taking the results from hypothesis 1 to hypothesis 5 into consideration, this study ratifies the results of Smith et al. (2014). The extension of the model is composed by Hypothesis 6 to Hypothesis 8 . The positive relationship between family culture and performance, the main objective of this study, as well as the positive relationship between family culture and relationship value were not confirmed by the proposed model, since hypothesis 6 and hypothesis 7 were rejected at $p=0.273$ and $p=0.712$ respectively. One possible explanation for the rejection of both hypotheses is indicated by Hair et al. (2018) as observed heterogeneity, which occurs when existing differences between two groups emerge from a characteristic that can be observed by means of a question. Hair et al. (2018, p. 136) adverts that the "failure to consider such heterogeneity can be a threat to the validity of PLS-SEM results". Further research is indicated. Hypothesis 8 predicts a positive relationship between relationship value and performance and was accepted at $p=0.00$. A more in-depth discussion of all hypotheses will be provided in section 6.3 - discussion of the results. 
Hair et al. (2017) proposes three categories (weak 0.25, moderate 0.50, or substantial 0.75) for research in marketing discipline to classify $\mathrm{R}^{2}$ levels of predictive accuracy. Taking these standards into consideration, the prediction of trust was at a very low level $(\mathrm{R} 2=0.06)$, the prediction of relationship value was at a higher level, but still below moderate $(\mathrm{R} 2=0.39)$ and the prediction of performance was positioned between the moderate and weak level $(\mathrm{R} 2=0.32)$. The only prediction above the line of moderate was the prediction of commitment $(\mathrm{R} 2=0.67)$. It is additionally argued that explaining $32 \%$ of the variance in the value of performance is not only meaningful but also crucial to the extension of the model. Due to a lack of previous research analyzing the relationship between family culture and performance in family organizations, this variance has yet to be explored. 


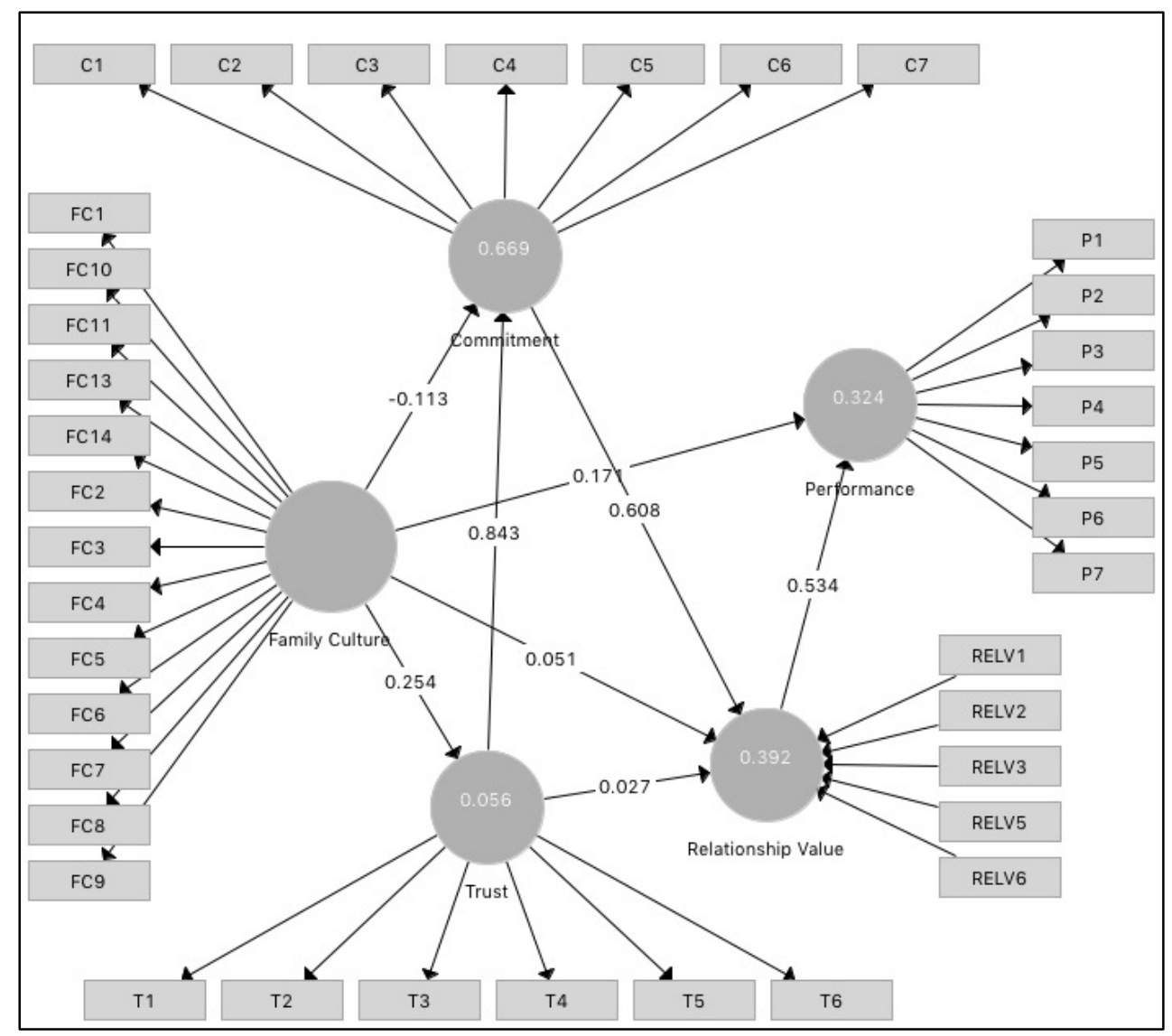

Figure 3: Model with the $\mathrm{R}^{2}$ and the significance test results of the paths to the constructs.

The last step to assess the structural model is to conduct a blindfolding procedure to evaluate the predictive relevance of the endogenous latent constructs in the model (commitment, trust, relationship value, and performance). An omission distance of $\mathrm{D}=7$ was applied. Hair et al. (2017) classified a small, medium, or large predictive relevance by $\mathrm{Q}^{2}$ results of $0.02,0.15$, and 0.35 , respectively. The $\mathrm{Q}^{2}$ for commitment was 0.439 , above the large predictive relevance benchmark indicated by Hair et al. (2017). The $Q^{2}$ for trust was 0.051 , between small and medium predictive power. Performance and relationship value presented respectively $\mathrm{Q}^{2}$ values of 0.247 and 0.233 , slightly below the large predictive relevance benchmark. A summary of the path coefficients analysis as well as the total effects is provided in Table 6. 


\begin{tabular}{|l|c|c|c|c|c|c|}
\hline \multicolumn{7}{|c|}{ Significance Testing Results of the Structural Model Path Coefficients } \\
\hline & Path Coefficients & $t$ Values & $p$ Values & $\begin{array}{c}95 \% \text { Confidence } \\
\text { Intervals }\end{array}$ & $\begin{array}{c}\text { Sgnificance* } \\
(p<0.05)\end{array}$ & $\begin{array}{c}\text { Hypothesis } \\
\text { number }\end{array}$ \\
\hline FAMCULT - COMMIT & -0.113 & 0.98 & 0.115 & {$[-0.318,0.137]$} & No & H1 \\
\hline FAMCULT - TRUST & 0.254 & 2.021 & 0.043 & {$[-0.144,0.459]$} & Yes & H2 \\
\hline TRUST - COMMIT & 0.843 & 15.373 & 0 & {$[0.691,0.921]$} & Yes & H3 \\
\hline COMMIT - RELVAL & 0.608 & 3.353 & 0.001 & {$[0.205,0.919]$} & Yes & H4 \\
\hline TRUST - RELVAL & 0.027 & 0.12 & 0.904 & {$[-0.499,0.385]$} & No & H5 \\
\hline FAMCULT - PERFOM & 0.171 & 1.097 & 0.273 & {$[-0.12,0.457]$} & No & H6 \\
\hline FAMCUL - RELVAL & 0.051 & 0.369 & 0.712 & {$[-0.179,0.355]$} & No & H7 \\
\hline RELVAL - PERFOM & 0.534 & 5.675 & 0 & {$[0.316,0.695]$} & Yes & H8 \\
\hline
\end{tabular}

* We refer to the bootstrap confidence intervals for significance testing.

Table 7: Results summary for structural model

\subsection{Assessment of the Measurement Invariance of Composites}

Marketing scholars have ample exposure to and experience with analyzing different groups of respondents in order to provide additional insights to their research (Henseler, Ringle, \& Sarstedt, 2016). In fact, analyzing the full dataset instead of recognizing the heterogeneity between groups would produce an incomplete picture of the relationships proposed by the model (e.g. Hair et al., 2018; Sarstedt \& Ringle, 2010). However, before undertaking a multigroup analysis, it must be ensured that the number of respondents in each group is in accordance with the minimum sample size requirements (Hair et al., 2018).

Since different generations within the family firm are going to be investigated, the groups in this study were defined according to the respondent's generation. Question FB2 (Figure 4) from the questionnaire was used to determine the generation. The first group, which is composed of 64 respondents, corresponds to the first generation. The second group, which is composed of 55 
respondents, corresponds to the second, third, fourth, and following generations. These groups will be referred to as the founder group and the successor group, respectively.

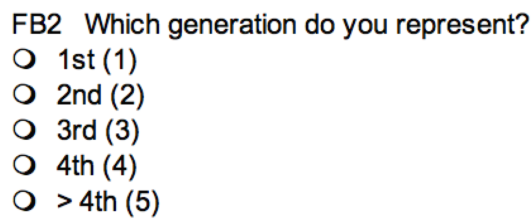

Figure 4: Question FB2 from the Family Business Questionnaire (Smith et al., 2014).

As discussed in section 4.4, the maximum number of arrows pointing at a single construct in the model is 7. Using Cohen's (1992) more rigorous recommendation as a rule of thumb, 51 observations per group are required to detect R2 values of around 0.25 at a significance level of $5 \%$ and a power level of $80 \%$ (Hair et al., 2017, p. 26). Therefore, since the groups present more than 51 respondents, the sample size is justifiably sufficient.

Besides the number of observations for each group, Henseler et al. (2016, p. 405) advised that "group comparisons can be misleading unless researchers establish the invariance of their measures". In fact, due to the risk of ambiguous group comparisons, the invariance of measures must be provided by researchers when using structural equation modeling (SEM). The measurement invariance of composite models (MICOM) procedure was developed to verify if the same measurement model was used between distinct groups of respondents (Garson, 2016). In order to analyze measurement invariance of composite (MICOM) in the model, the three-step procedure proposed by Henseler et al. (2016) will be applied. The MICOM procedure involves three hierarchical steps: (1) configural invariance, (2) compositional invariance, and (3) the equality of composite mean values and variances. Therefore, researchers must establish step (1) 
in order to move on to step (2) and so on. When steps (1) and (2) are fulfilled, "partial measurement invariance" is established. "When partial measurement invariance is confirmed for all latent variables in the PLS path model, researchers can compare the path coefficients by means of a multigroup analysis" (Hair et al., 2018, p. 141).

(Step 1) - Configural invariance

The assessment of configural invariance is a qualitative process. Identical indicators per measurement model, identical data treatment, and identical algorithm settings must be established across all the groups in the study. An analysis of Smart PLS settings as well as the data treatment was conducted. Taking into consideration that the study applied identical indicators' data treatment and identical algorithm setting across all different groups presented in the model, configural invariance was established (Hair et al., 2017).

(Step 2) - Compositional invariance

A permutation algorithm is often used to compare groups as well as to implement MICOM (Garson, 2016). Therefore, a permutation test was undertaken to evaluate compositional invariance. Permutation p-values, which indicate if the item loadings in the outer model are invariant across groups, lower than 0.05 were found for commitment and relationship value (table 7), indicating a compositional variance. An outer weights analysis identified p-values lower than 0.05 for the following items: commit_01, commit_02, commit_07, and relv_01. These items were deleted from the model and a second permutation test was performed (Table 8). All permutation p-values were above the 0.05 threshold recommended by Henseler et al. (2016). 


\begin{tabular}{|l|c|c|c|c|}
\hline \multicolumn{5}{|c|}{ MICOM STEP 02 } \\
\hline & Original Correlation & Correlation Permutation Mean & $5.00 \%$ & Permutation p-Values \\
\hline Commitment & 0.997 & 0.999 & 0.998 & 0.002 \\
\hline Family Culture & 0.994 & 0.935 & 0.796 & 0.946 \\
\hline Performance & 0.999 & 0.999 & 0.997 & 0.773 \\
\hline Relationship Value & 0.645 & 0.89 & 0.761 & 0.004 \\
\hline Trust & 1 & 1 & 0.999 & 0.471 \\
\hline
\end{tabular}

Table 8: Results summary for MICOM step (2)

\begin{tabular}{|l|c|c|c|c|}
\hline \multicolumn{5}{|c|}{ MICOM STEP 02 (after removing Commit_01, Commit_02, Commit_07, and RelVal_01) } \\
\hline & Original Correlation & Correlation Permutation Mean & $5.00 \%$ & Permutation p-Values \\
\hline Commitment & 1 & 0.999 & 0.998 & 0.978 \\
\hline Family Culture & 0.992 & 0.929 & 0.757 & 0.897 \\
\hline Performance & 1 & 0.999 & 0.997 & 0.892 \\
\hline Relationship Value & 0.733 & 0.825 & 0.581 & 0.200 \\
\hline Trust & 1 & 1 & 1 & 0.57 \\
\hline
\end{tabular}

Table 9: Results summary for MICOM step (2) after composites were removed from the model

Garson (2016) indicates that a finding of non-significance $(>0.05)$ means that compositional invariance may be assumed.

(Step 3) - Equality of mean values and variances

According to Henseler et al. (2016) the equality of mean and variances is mandatory only when running analysis on the pooled data level. Since the main objective of this work is to propose a multigroup analysis, only configural and compositional invariance are mandatory, steps (1) and (2) respectively. Garson (2016, p. 186) confirms that when steps (1) and (2) are concluded, 
"partial measurement invariance" is established; therefore, the researcher may proceed with a multigroup analysis if the purpose of the study is to compare structural paths across groups. Considering that configural and compositional invariance were established and the objective of the present study is to compare structural paths between two groups, it can be concluded that the model presents the mandatory conditions proposed by Henseler et al. (2016).

\subsection{Assessment of Multigroup Analysis MGA}

Succession is a key element of differentiation between a family and a non-family organization; hence, "one of the most critical issues in the continued life of a family business" (Cater et al., 2016, p. 301). The ultimate goal of this multigroup analysis is to investigate if there is a difference in the identification of family culture as an influencer of performance for founders and successors, which represent the two distinct groups of respondents. One of the main objectives of the MGA is therefore to identify if the PLS model significantly differs between groups for measured variables (Garson, 2016).

According to Sarstedt et al. (2011), due to a procedure that takes into account all comparisons between bootstrap coefficients, the PLS-MGA method is an extension of Henseler's approach (2007) to check the significance of absolute differences between two groups of data. The PLSMGA method is, among all existing methods, the most conservative one and the one applied in this study.

Groups were created on Smart-PLS and PLS-algorithm was calculated in order to produce the absolute differences between paths. Multigroup analysis (MGA) procedure was undertaken following instructions provided by Sarstedt et al. (2011) and the results are presented in Table 9. PLS MGA probabilities results lower than 0.05 and higher than 0.95 indicate a significant result 
(Sarstedt et al., 2011). As observed on Table 9, the path from family culture to performance is significantly different at 0.988 between the two groups. This result ratifies that, when investigating the influence of family culture on performance, an analysis between founders and successors will produce a relevant result; therefore, a more accurate explanation of the influence of different actors and their respective behavioral factors in business outcomes as well as a greater understanding of family enterprises.

\begin{tabular}{|l|c|c|}
\hline & $\begin{array}{c}\text { Path Coefficients-diff } \\
\text { (Generation1 - Generation2) }\end{array}$ & $\begin{array}{c}\text { PLS MGA Probabilities } \\
\text { (Generation1 vs Generation2) }\end{array}$ \\
\hline Commitment -> Relationship Value & 0.04 & $0.453^{*}$ \\
\hline Family Culture -> Commitment & 0.136 & $0.691^{*}$ \\
\hline Family Culture -> Performance & 0.574 & 0.988 \\
\hline Family Culture -> Relationship Value & 0.552 & $0.07^{*}$ \\
\hline Family Culture -> Trust & 0.319 & $0.924^{*}$ \\
\hline Relationship Value -> Performance & 0.226 & $0.15^{*}$ \\
\hline Trust -> Commitment & 0.249 & $0.068^{*}$ \\
\hline Trust -> Relationship Value & 0.614 & $0.923^{*}$ \\
\hline
\end{tabular}

Table 10: Results for PLS-MGA analysis.

* PLS MGA probabilities results lower than 0.05 and higher than 0.95 indicate a significant result (Sarstedt et al., 2011). Taking this indication into consideration, the other hypotheses tested with this model did not produce a significant PLS MGA probabilities result, and for this reason, were not discussed when analyzing different generations. On the other hand, hypothesis 6 presented a significant result. For the founders' group, family culture does not positively impact performance. As can be observed in Figure 5, the coefficient path is 0.072 . However, when considering the successors, the path coefficient is 0.646 , which indicates that, for this group, family culture does positively influence business performance, as illustrated in Figure 6. 


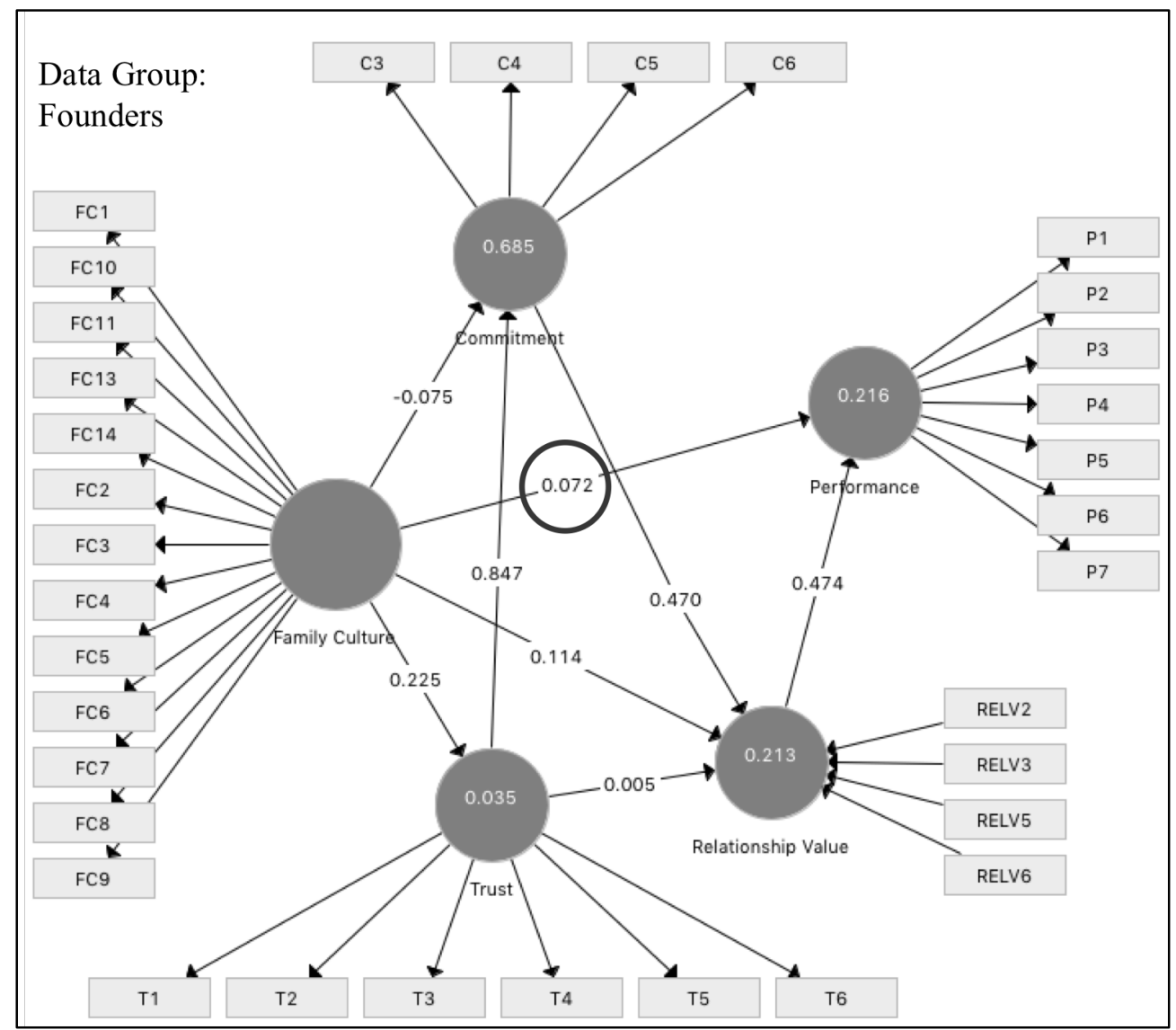

Figure 5: $\mathrm{R}^{2}$ and the significance test results of the paths to the constructs for Founders data group. 


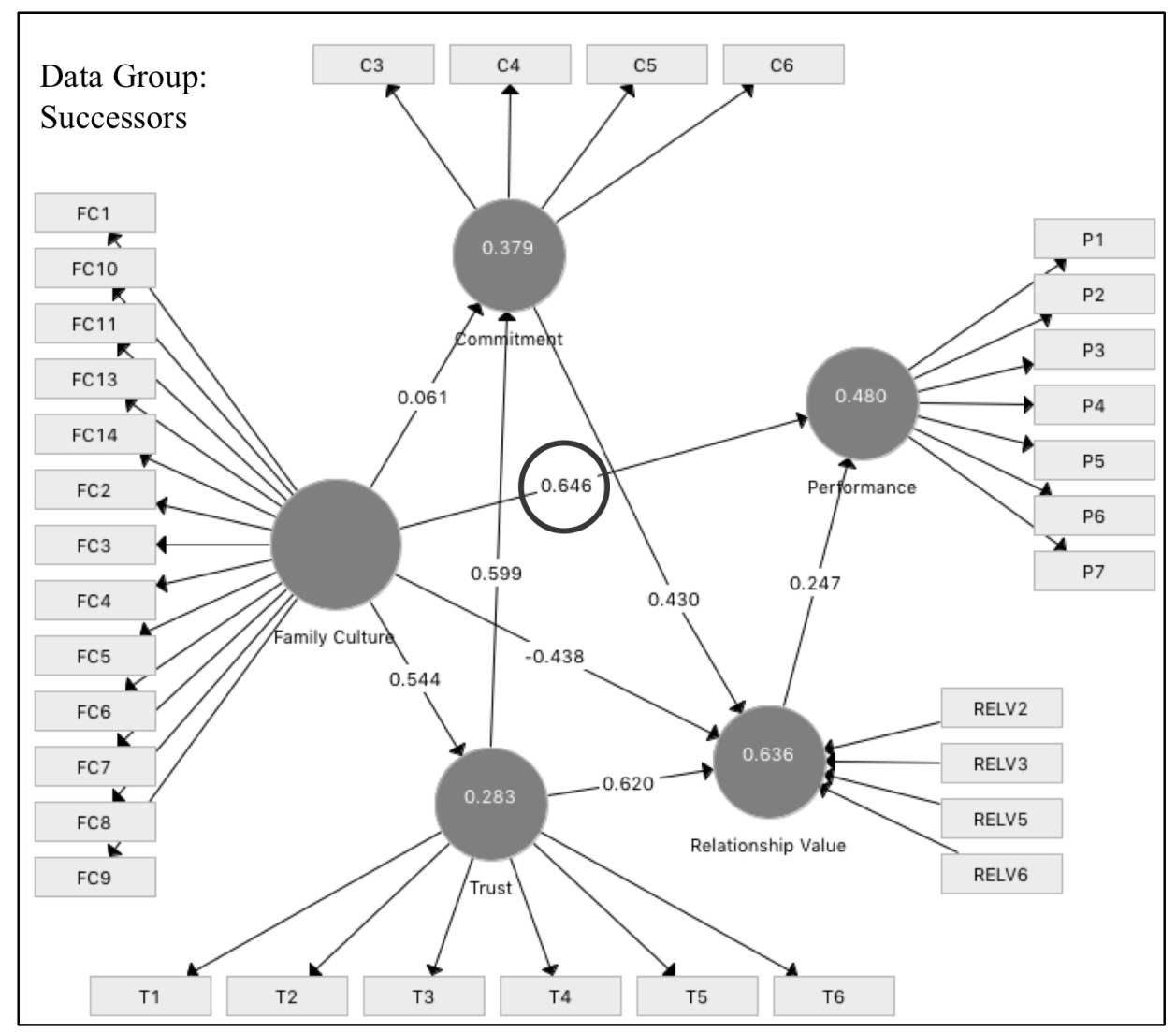

Figure 6: $\mathrm{R}^{2}$ and the significance test results of the paths to the constructs for Successors data group 


\section{Summary and Discussion}

This chapter will underline the interpretation of the findings as well as give prominence to the relationship between said findings and existing discourse. It additionally calls attention to the implications of theory and practice. To begin, the research question is re-stated in order to provide an overview of the project. As important as the lengths this research can extend to are, the limitations are just as insightful and are presented with suggestions for further investigation in the conclusion of this chapter along with the acknowledgements for this particular research study.

It has been established throughout that this study was conducted to develop and test a model in an attempt to explore the influence of culture in family firms' performance in retailer-vendor strategic partnerships. Through quantitative research, oriented by a deductive approach, the proposed model tested eight hypotheses in the context of the retail marketplace in the United States of America. However, before advancing to a summary of the results, the questions that this current study is aiming to answer must be re-stated.

\subsection{Statement of the Research Question}

The focal point of the research was identified in Section 1.4.1 (Research Question), which outlined the principle research questions and objective. This section additionally identified the scope of the questions while paying homage to previous research with which this project finds some relation. Beginning with Donnelley's (1964) list of questions to analyze if family management was opposite to free competition, then Denison's et al. (2004) concern with the "bit of magic" that provides a family firm an unique power, and finally taking into consideration Rod's (2016) investigation about the implications of family participation in a business, it is 
clearly evident that a considerable number of studies were reviewed in order to relate the proposed question to previous research, establishing its relevance.

In summary, the following research questions were proposed:

- How does family culture impact trust?

- Does family culture influence the level of commitment to the business?

- How does family culture impact relationship value in a retailer-vendor strategic partnership?

- How does family culture affect the performance of family firms in retailer-vendor strategic partnerships? Is that influence positive or negative? Does family culture improve or hinder firm performance?

- Is there a difference in the recognition of culture as an influencer of performance considering different generations in the family firm?

\subsection{Summary of Results}

In light of the proposed theoretical model, which was used throughout this study, a total number of 8 hypotheses were tested. As previously mentioned, 5 were previously tested in a study that analyzed family influence in commitment and trust, conducted by Smith et al. (2014). The last 3 hypotheses, however, are novel; in fact, one of those 3 hypotheses represents the main objective of this study, which is to investigate the influence of family culture on performance.

In order to summarize the results as well as facilitate the reading of the results, a list of the hypotheses and their respective results are provided. Nevertheless, a discussion and interpretation of the meaning of these results is provided in the next section. 
- H1 (there is a positive relationship between family culture and commitment in retailervendor strategic partnerships) - this hypothesis was rejected due to a lack of significance $(\mathrm{p}=0.115)$, aligned with previous research concluded by Smith et al. (2014);

- $\mathrm{H} 2$ (there is a positive relationship between family culture and trust in retailer-vendor strategic partnerships) - this hypothesis was accepted, with a significant result ( $\mathrm{p}=0.043$ ), aligned with previous research concluded by Smith et al. (2014);

- H3 (there is a positive relationship between commitment and trust in retailer-vendor strategic partnerships) - this hypothesis was accepted, with a significant result $(\mathrm{p}=0.000)$, aligned with previous research concluded by Smith et al. (2014);

- $\mathrm{H} 4$ (there is a positive relationship between commitment and relationship value in retailer-vendor strategic partnerships) - this hypothesis was accepted, with a significant result ( $\mathrm{p}=0.001)$, aligned with previous research concluded by Smith et al. (2014);

- H5 (there is a positive relationship between trust and relationship value in retailer-vendor strategic partnerships) - this hypothesis was rejected due to a lack of significance $(\mathrm{p}=0.904)$, aligned with previous research concluded by Smith et al. (2014);

- H6 (there is a positive relationship between family culture and performance in retailervendor strategic partnerships) - this hypothesis was rejected due to a lack of significance $(\mathrm{p}=0.273)$

- $\mathrm{H7}$ (there is a positive relationship between family culture and relationship value in retailer-vendor strategic partnerships) - this hypothesis was rejected due to a lack of significance $(\mathrm{p}=0.712)$; 
- H8 (there is a positive relationship between relationship value and performance in retailer-vendor strategic partnerships) - this hypothesis was accepted, with a significant result $(\mathrm{p}=0.000)$.

Hypothesis 6 was rejected. The relationship between family culture and performance is the main concern of this project. Taking into account that previous studies concluded that organizational culture influences performance (e.g., Barney, 1986; Denison et al., 2004) and there is no distinction between organizational culture and family culture (Hollander \& Bukowitz, 1990), as well as the fact that information from different generations is available in the database, the research was advanced one level further by investigating if different generations in a family firm will respond differently to the influence of family culture in performance. More specifically, a distinction between this response between the founder generation (the first generation of the business) and the successor (second, third, and so on) generations.

As a result, a multigroup analysis (MGA) on PLS-SEM was conducted and the results illustrated the validity of this investigation. In order to provide an objective description of the results of the MGA on Hypothesis 6, a list will be provided:

- The path coefficients absolute difference was considerable $=0.574$;

- The PLS MGA probabilities result was significant $=0.988$;

Hair et al. (2018) advises that, since PLS-SEM represents a one-tailed test, in order to assess whether the difference is significant from the second group (successors in our analysis) to the first group (founders in our case) we must take 1-p value. Therefore, this calculation will produce a significant $p$ value of $1-0.988=0.012$. 
- Generation 1 (founders) - family culture does not positively influence performance (path coefficient $\mathrm{p}=0.072$;

Generations $2,3,4 \ldots$ (successors) - family culture does positively influence performance (path coefficient $=0.646$ );

A more in-depth discussion of these results can be found below.

\subsection{Discussion of the Results}

Almost three decades ago, Dyer (1988) realized that more than two-thirds of organizations that were moving from first generation to successors changed their management culture from "paternalistic" to a "professional" style of management. A paternalistic management style is characterized by a centralization of power and control, especially in the hands of the founder, while professional management moves towards a more inclusive environment, where leaders are encouraged to make decisions regardless of whether they are part of the family (Dyer, 1988). A decade after Dyer's (1988) research, another study that investigated large publicly-owned founding-family-controlled companies, conducted by McConaughy and Phillips (1999), reached a similar conclusion, that companies ran by successors presented a more professional management style than companies managed by founders.

Taking all of the above into consideration, it has been concluded that this change of management style could also represent changes in the perception of other elements playing a role in the family firm, such as family culture. The next section reflects on the findings of each of the hypotheses, whether they were accepted or not. The aim of this reflection is to bring the meaning of our study to surface. 


\subsubsection{Interpretation of the Findings}

Before undertaking the interpretation of the findings and the exploration of their results, the sequence of the hypotheses must be explained. Throughout this section, all hypotheses will be discussed; however, the order of hypotheses is based on the importance of findings. It will follow a numerical order but jumping Hypothesis 6, considering that this hypothesis is directly connected to the purpose of this study, which will be discussed in the final stages.

The first hypothesis, which proposed a positive relationship between family culture and commitment in retailer-vendor strategic partnerships, was rejected. This hypothesis was justified based on the notion that family culture is a representation of the interaction of family values and the business itself (Astrachan et al., 2002), in this particular case, the family firm. To propose this hypothesis this study additionally adhered to the concept that values are the foundation of culture (e.g., Denison et al., 2004; Schein, 1985). Therefore, it has been concluded that the interactions of family values and business would give rise to a culture that could influence individuals to develop a higher level of commitment to the strategic partnership that they are involved with.

In their study about stewardship perceptions in family business, Davis et al. (2010) pointed out that commitment is an illustration of a solid connection or a binding relationship. In addition, Mowday et al. (1982) stated that the extent that an individual is involved in a particular organization or is committed to it is proportional to the acceptance of this organization's goals and values. Finally, Deal and Kennedy (1982) added that culture could influence employees, depending on the extent that employees recognize a sense of purpose, and that sense of purpose will result in a remarkable commitment. 
Commitment, according to Meyer and Herscovitch (2001), is a state of mind or a psychological state that influences an individual's actions. All in all, the fact that the hypothesis that there is a positive relationship between family culture and commitment was not confirmed could be justified by two possible explanations. First, individuals could not be in accordance with the partnership's goal; therefore, they would not demonstrate commitment to it; and second, the technique used to measure shared values in this research. Differently than Morgan and Hunt (1994), who used a two-step process to measure share values, this study applied the family culture scale developed by Astrachan (2002). In other words, the two-step technique was not used in this research since family culture is focused exclusively in organizations. This difference of process could justify the rejection of Hypothesis 1.

The second hypothesis proposed a positive relationship between family culture and trust in retailer-vendor strategic partnerships, which was confirmed by the model. The main support for this hypothesis was based on the work of Morgan and Hunt (1994) who stated that values measured by family culture scales resulted from the same conceptual model as shared values. In other words, the outcome of family culture that is being captured by using Astrachan's (2002) culture subscale from the F-PEC scale in the theoretical model results from the same model as shared values. Shared values were defined by Morgan and Hunt (1994, p. 25) as “...the extent to which partners have beliefs in common about what behaviors, goals and policies are important or unimportant, appropriate or inappropriate, and right or wrong."

The definition of trust in the realm of family business literature is a combination of psychological, organizational, and interorganizational processes (e.g. Eddleston et al., 2010; Rousseau et al., 1998). The parent-child trust relationship observed by Lumpkin et al. (2008) 
starts when children increase their effort to impress parents, and by doing so children are developing a sense of safety and protection, in other words, a sense of belonging. Taking into consideration that with trust employees share a sense of belonging not only to a family but also to an organization, and with trust relationships are reinforced (Sundaramurthy, 2008), it can be concluded that the family values captured by the measurement of family culture in the model ratified the importance of being part of something bigger, the importance of building relationships. Hence, confirming the importance of trust.

A positive relationship between commitment and trust in retailer-vendor strategic partnerships was confirmed on Hypothesis 3. Almost a decade ago, Davis et al. (2010) published "Is blood thicker than water?" establishing a positive relationship between stewardship and trust. The first conclusion, based on Davis et al.'s study as well as model results, is that trust and commitment share the same goal, which is the best interest of the business. The relationship commitment scale developed by Morgan and Hunt (1994) was also a very important theoretical foundation for this hypothesis. Not only this theory but also the fact that the best interest of the business is the main objective of both, trust and commitment (J. Davis et al., 2010).

Different levels of commitment in marriage, an example of an affective commitment, were highlighted by Allen and Meyer (1990) in order to provide evidence of different levels of commitment. Therefore, different levels of commitment could influence trust differently. These results also ratify Smith et al. (2014), who concluded that commitment should be considered a source of competitive advantage, due to its positive influence in family firms. If trust is considered an important foundation of a partnership, in other words, with no trust it is difficult to build up a partnership, the main conclusion after analyzing model results is that commitment 
should be considered a family business asset due to its importance as a positive influencer of trust as well as a source of competitive advantage.

In the same way that the model confirmed a positive relationship between commitment and trust, it also confirmed a positive relationship between commitment and relationship value in retailervendor strategic partnerships, which is Hypothesis 4. A traditional approach to measure relationship value in family business literature is to consider shareholder value or even equity (Sindhuja, 2009). Entrepreneurial orientation and knowledge as well as negative aspects, such as family inertia, were used by scholars to come up with a value creation framework (Chirico \& Nordqvist, 2010). In this study, Milton's (2008) recommendation that five years is the minimum period necessary to develop long-term commitment was highly regarded.

Organizational culture was defined as the intersection of business and family commitment (Corbetta \& Salvato, 2004). Taking this definition into consideration, it has been concluded that through commitment employees will identify themselves with the organizational culture. The definition of relationship value proposed by Ulaga and Eggert (2006) positioned relationship value in a model that contained commitment and trust as well. They defined relationship value as a set of trade-offs and a recent study concluded by Smith et al. (2014) expanded this definition to consider accessible options and the achievement of mutual goals. To conclude, when employees identify themselves with the organizational culture, and if this culture is oriented to enhance competitiveness and profitability throughout partnerships, employees are in fact creating relationship value, which is confirmed by the study of distributional channels relationships concluded by Vázquez et al. (2005) . 
Moving on, Hypothesis 5, which proposed a positive relationship between trust and relationship value in retailer-vendor strategic partnerships, was rejected. A similar hypothesis was rejected in Smith et al. (2014, p. 258) research. This hypothesis was supported by the claim that with trust, employees collaborate more with each other in the firm (Steir, 2001). Based on this claim, it was initially deduced that in a relationship based on trust, better outcomes could be expected; hence it was proposed that trust would positively influence relationship value. However, since the model rejected this hypothesis, the main conclusion is that more employee collaboration does not necessarily result in better outcomes for the firm. This interpretation is fully aligned with Ingram's (1996) investigation of the link between teamwork and performance. Teamwork is an useful strategy to improve organizations' results only when those organizations invest time to develop collaboration among employees, and top managers encourage teams to work together and make decisions in a collaborative way (Ingram, 1996).

Hypothesis 7, since the sixth has been left to the end, proposed a positive relationship between family culture and relationship value in retailer-vendor strategic partnerships, which was rejected by the model. Considering what has been stated several times throughout this study, values are the foundation of culture (Denison et al., 2004); therefore, depending on the core values established by the family, a different type of family culture could be expected. The four-type classification of families proposed initially by Kantor and Lehr (1975) and endorsed by Constantine (1993) also ratifies the existence of different types of culture. According to those studies, depending on the beliefs, values, dynamics and paradigms represented by the families, four types of families ranging from closed paradigm to synchronous paradigm can be identified. In summary, four different types of families with different values will generate different cultures. 
This differentiation among families was highlighted as an important perspective to understand why certain families were successful in their business and others were not (Dyer, 2006). Additionally, it has been concluded that, depending on the values nurtured by the family, a different culture would be developed, with no particular emphasis on relationship values. Hypothesis 8 proposed a positive relationship between relationship value and performance in retailer-vendor strategic partnerships and was confirmed. If relationship value is the outcome of the cooperation process between companies that are building new skills, saving resources, sharing risks and also moving towards new investments (Hutt et al., 2000), the possible benefits of this association are the increase of sales volume and profit, as well as access to new technologies and markets (Ryssel et al., 2004). This study has also adopted Hult's et al. (2003, p. 430) definition of performance as "the achievement of organizational goals related to the profitability and growth in sales and market shares, as well as the accomplishment of general firm strategic objectives". In conclusion, by confirming this hypothesis, this study is confirming that not only does relationship value lead to competitive advantage but also better business performance.

Hypothesis 6, which is giving title to this study, was rejected and proposed a positive relationship between family culture and performance in retailer-vendor strategic partnerships. This result was contrary to Hollander and Bukowitz's (1990) claim that in a family firm organizational culture and family culture are inseparable, in other words, one in the same. Initial results were also contrary to Barney's (1986) study about organizational culture and Denison's (2004) work about culture in family-owned firms, since both scholars proposed a positive relationship between organizational culture and performance. Rather than looking for theoretical 
support for initial results, it was decided to move the investigation further and investigate if there is a difference within the response of family culture as a driver of performance in family firms when considering different generations. The recognition of different aspects or even a stronger intensity of recognition when considering different generations in the family firm is well supported in literature (e.g. Dyer, 1988; McConaughy \& Phillips, 1999; Schein, 1983). This new outlook was confronted by the question of whether there is a distinction in the response of family culture as a driver of performance in the context of different generations within the family firm. More precisely, if there is a distinction between the founder and the successor generations in the way family culture influences the performance in the family firm.

The decision to move further with the investigation is well supported in literature. For example, Sonfield and Lussier's (2004) investigation of the differences among first, second and thirdgeneration family firms. Their first conclusion was highlighting the different forms of management considering different generations. For instance, first generation family members are entrepreneurs, with the skills necessary to create the business; therefore, they tend to use patriarchal and hierarchical forms of management. On the other hand, the successor generations, having to deal with different challenges to maintain the business, tend to use a more professional form of management. This conclusion was similarly supported decades ago (e.g. Dyer, 1988; McConaughy \& Phillips, 1999; Schein, 1983). Since those forms of management presented different values and beliefs and values are the foundation of culture, a different outcome on the response of family culture as a driver of performance could be expected if different generations in the family firm are considered. 
This idea of difference among generations is supported by other studies, such as the research covering the trends in family business conducted by Aronoff (1998) which highlighted that the successor generation tends to engage in a more collaborative environment, where each family member is able to participate, regardless of his position in the firm. The literature also provides support for the investigation regarding differences among generations if conflicts among family members is considered. There is a study concluded by Beckhard and Dyer (1983b) that asserted that the conflicts among family members increases as the number of generations taking part in the family firm.

The decision to include a generational perspective within the investigation is also supported by evidence of an organization that is facing challenges during the succession process. Darcars Automotive Group, a leader in its segment in the auto industry, is a family firm, with an uncertain future (Jamie, 2015). Recently, a member of the second generation filed a lawsuit against the founder of the company who is also her father. She is alleging that the founder of the company failed to honour his promise of making her the next CEO. According to consultants, this law suit could terminate the company.

Both theoretical and practical support has been found to validate the investigation of whether there is a difference in the way different generations respond to the influence of family culture in performance. The results were solid and confirmed this hypothesis. Therefore, if the founders' generation is considered, family culture does not positively influence performance. The interpretation of this result is based on the fact that the founder of the company is the ultimate representation of the culture itself, just like observed in the Darcars Automotive Group example. Hence, the founder is the culture itself, making it difficult to recognize as a driver or source of 
competitive advantage. In a symbolic analysis, the founder and the firm are the same, the business is the link of the founder with the real world (Zaleznik \& Kets de Vries, 1985).

However, if the successor generation is considered, formed by all generations following the founder, family culture does positively influence performance. A recent study conducted by Cater et al. (2016) concluded that two of the four factors that successors take into account to accept the invitation to work in the family firm are the opportunity to work for different organizations before entering the family firm and the history of the family business itself. If it is assumed that the history of the family business itself is connected to the history of the family, it can be concluded that the family culture plays a main role in forming this history. As successors are encouraged to work for other organizations before assuming their position in the family business (e.g., Cater et al., 2016; Danco, 1982; Nelton, 1986), they bring with them aspects from those corporate cultures. The more space successors have to propose their ideas, bring their experience, and achieve mutual respect with the founder, the more successful the succession process will be (Handler, 1994). The challenge faced by successors, who worked for other organizations prior to entering a family firm, could be twofold; while they have been exposed to other organizational cultures that may add something to the family firm, they must also maintain the existing family culture. This possible paradox is the justification itself for the positive response provided by the successor generation about the influence of family culture in a family firm performance. In a recent survey, PWC (2014) highlighted a trend among family organizations that are requesting an external development training program to young family members before assuming their position in the family firm. In other words, family firms are 
asking their young members to work for different organizations in order to acquire experience before entering the firm.

A good example of a successful management transition with the recognition of the organizational culture is Kaplan Construction. The family firm was founded in 1976, and recently they announced the conclusion of a three-year succession process (Kaplan, 2014). Throughout this transition of power, the founders of the company recognize not only technical aspects but also values that the second generation will maintain. Ken Kaplan, the founder of the company states:

\footnotetext{
"I step away from the president's role with the full confidence that Nate and Jane will continue to follow our guiding principles of client service, technical excellence, collaboration and mutual respect. I know the company will thrive with them at the helm, and Cathy and I look forward to providing support and leadership as they continue to grow the company."
}

In his work about "culture and continuity" in family firms, Dyer (1988) brought to light that founders must consider the effects of an organizational culture on successors; ratifying the final conclusion of this study that there is a considerable difference within the way founders and successors respond to the influence of family culture in performance. This final conclusion is also supported by the concept of "shadow" proposed by Sonfield and Lussier (2004), which discussed the idea of the "shadow" of the founder in the family firm as an analogy to the founder's values, direction and standards. This concept of "shadow" was also investigated by Davis and Harveston (1999), who concluded that if the centralized role of the founder is a value of the organizational system, then, both generations, regardless of the physical presence of the founder, will be influenced by the values, beliefs, ideas and concepts of the founder; in other words, the founder's culture. A similar conclusion about the influence of the founder of a family 
firm in succeeding generations was presented by Kelly, Athanassiou and Crittenden's (2000) work. However, in the latter, the authors pointed out that the influence of the founder on subsequent generations could be positive or negative. In a recent family business survey, PWC (2014) addressed the "shadow" of the founder concept (Sonfield \& Lussier, 2004) as the "sticky baton" syndrome, where the founder of the company hands over management of the company exclusively in theory. In practice, the founder refuses to transmit the control and is still responsible for making all strategic decisions. In fact, $41 \%$ of the founders that answered the survey (PwC, 2014) admitted it would be difficult to let go.

The conclusions of this study are also based on Lansberg's (1988) statement about the several changes that the succession process enforces, in the case of a family firm, to both: the family and the firm. Those changes are the re-organization of family influence, the rise of new organizational structures, and the re-construction of family relationship. It is also believed that the recognition of family culture as a driver of a family firm performance is one those changes imposed by the succession process. According to Amy's (2016) article for the New York Times, only $30 \%$ of the family firms survive after the succession process from the first to the second generation. According to the author this phenomenon is known as "the second-generation curse". All in all, there is substantial confidence that the main finding in this research is well supported by literature and practice.

\subsubsection{Theoretical Implications}

This thesis was constructed based on previous studies, which opened the door to an understanding of family business aspects and characteristics, in other words, family business as a field of study. The research method that informed this study was chosen based on previous 
research that also contributed to the selection process of research tools and scales as well as to the interpretations of findings. The work of scholars that has been developed for many years is, therefore, a crucial part of this study.

Ideally, this study can contribute something valuable that furthers the investigation of family firms in the field of family business. This research fills the gap between family culture and performance as well as confirms the identification of family culture as a positive influencer of performance in family firms in retailer-vendor strategic partnerships, especially in regards to the successor generation. By finding evidence of a difference in the response if family culture is a positive influencer of performance between different generations, this project ratifies the work concluded by Lansberg (1988), which highlighted all the changes that took place during a succession process in a family firm. The results are also aligned with the work of Gersick et al. (1997) and the role of the founder, as the personification of the organizational culture itself, as the one in charge to construct, develop, and finally establish the foundations of the business. It additionally confirms Hollander and Bukowitz's (1990) suggestion that family culture and organizational culture influences businesses' outcomes, especially in family firms. In the same way, this study ratifies the evidence on how culture affects the dynamic capabilities of a family enterprise (Chirico \& Nordqvist, 2010); furthermore, highlighting family culture as a relevant aspect that needs to be taken into consideration when dealing with possible drivers of family businesses' performance.

Another important contribution to scholars provided by this work is the importance of analyzing different generations within the family firm. The role of the founder is different than the role of the successor, the family relationships are different after a succession process, the influential 
power inside the family is dislocated, and most importantly, the group of people involved in the business is changing; therefore, the perception of the environment and all forces at play is also distinct. Results confirm this conclusion and endorse the distinct perception by the first, the second, and the third generation explored by Sonfield and Lussier (2004).

The method that was used, PLS SEM, is becoming popular among scholars, especially after the publication of "PLS-SEM: Indeed a Silver Bullet" (Hair et al., 2011b) and "An Assessment of the use of Partial Least Squares Structural Modeling in Marketing Research" (Hair, Sarstedt, Ringle, \& Mena, 2012); however, the method is still novel (Hair et al., 2017). In fact, new advanced techniques, such as multigroup analysis and invariance, are being discussed in “Advanced Issues in Partial Least Squares Structural Equation Modeling” (Hair et al., 2018). By concluding this study and drawing the main conclusion from a multigroup analysis, it is possible that the advancement and development of this important research method, especially for family business research, could be aided by this research.

\subsubsection{Implications for Practice}

In practice, this work provides practitioners in the field with an orientation on how to consider important aspects, such as the family culture, when dealing with a family organization. For instance, consultants that are assisting family firms to build a succession process plan can use this study as a support to discuss cultural aspects, especially if the succession is from the founder's generation to the second generation in the family, with the family. Family cultural aspects, therefore, must be considered in the plan.

Steve Jobs is perhaps one of the most iconic founders of a business (Fowler, 2011). Apple clients are devoted to the company. According to Heidi Campbell, a scholar who researched the 
IPhone, one of Apple's revolutionary products, people feel devotion to Apple and his leader, and this devotion could be compared to that of a religion. Therefore, it is not a surprise that after Steve Jobs' resignation in 2011, a spokesperson from Apple recognized the importance of culture with the following statement:

"Apple is a company and culture unlike any other in the world and we are going to stay true to that. We are going to continue to make the best products in the world that delight our customers and make our employees incredibly proud of what they do."

Implications for the family firm management practice itself are significant. Both employees and family members are often involved in political issues and influential disputes inside the firm. Therefore, as part of the decision-making process within the firm, they need not only respect each other, but also work together towards the achievement of the firm's goals. It is believed that if both groups consider the conclusions highlighted in this work, such as: the role of the founder, the importance of the family culture as a performance driver, as well as the values that are used as the foundation of the family culture, it could result in a better understanding and recognition of each other's point of view ultimately resulting in the development of better relationships between family members and employees.

Members of the successor generation could also use this study as a way to open the lines of communication within the family firm in a collaborative way. Considering that they worked for different organizations before assuming their position in the family firm and they acknowledge that family culture is a positive influencer of performance, they can cumulatively establish which aspects of family culture should be maintained from within the family firm and which ones should be adopted from different organizational cultures. In other words, the successors can spearhead the "modernization" of the family culture. 
Al Majdouie is a Middle Eastern family conglomerate that was founded in 1965. The firm has 7,000 employees working across different countries. Nowadays, the second generation is running the company and they are in the process of transferring the managing positions to the third generation. According to the son of the founder and actual CEO of Al Majdouie, a lot of emotions and conflicts take place during a transition, that is why the succession plan will take at least three to five years. He emphasizes that values, the foundation of culture, are a crucial element during the succession process and to ensure the long-term survival of the family firm (PwC, 2014, p. 19).

\footnotetext{
"In some ways the soft part is even more important than the hard part. The hard part is governance, and the soft part is the values - the values that are embedded in the family members right from their childhood, and which they all share."
}

Perhaps, the group that will benefit the most from these findings is the group formed by founders of family firms. In this study, it has been concluded that, for this group, family culture dos not positively influence performance because they are the personification of the culture itself. Therefore, this study could provide a valid orientation for this group as well. In fact, founders of family firms can use this study as a source to guide them toward thinking about the values that they, as the ultimate personification of the family culture, will nurture in their family firms. Are those values oriented to individualism or teamwork? Are those values proposing a hierarchical decision-making process or an open one? Most importantly, are those values a source of competitive advantage to the firm? In conclusion, it is hoped that after reading this study, founders will start recognizing family culture as a positive influencer of performance, especially if their firms are part of a retailer-vendor strategic partnership. 
A good example of a strategic alliance, which took into consideration the values and the culture embraced by the company, is the partnership between Best Buy and Car Toys (Thomas, 2012). One of the values that Best Buy embraces is to help people with expertise information. A good example of the transformation of this culture into strategy is the "Geek Squad" team. When the vice president of Best Buy announced the partnership with Car Toys she highlighted "Best Buy is leveraging Car Toys' experience in servicing commercial customers, as well as our wealth of experience in specialized mobile electronics and installation." With this partnership, Best Buy is not only taking advantage of an existing value, which is a source of competitive advantage, but also entering the after-market car electronics space multi-billion dollar market.

\subsubsection{Limitations}

This research calls attention to the importance of considering family culture as a driver of family firms' performance. However, the perception of culture is a complex phenomenon that requires the disclosure of the limitations of this work.

The first limitation that should be highlighted is the source of data. Data was extracted from a database that was previously used and developed for another project, concluded by Smith et al. (2014). This database is exclusively composed of firms located in the United States, and part of the retail industry. Considering that the retail industry and family firms are relevant to the US economy (Smith, 2016), ratification of the results in another context should also be considered.

Regardless of geographic limitations, data was composed of firms involved in a business partnership with a major strategic partner, which was defined by "their most important vendor or supplier with respect to achieving a higher level of competitiveness over the next 3-5 years" (Smith et al., 2014, p. 258). Therefore, culture was investigated through the lens of retailer- 
vendor strategic partnerships, which is an important business relationship; however, it could potentially highlight cultural aspects. A question of whether family culture is acknowledged as a performance driver to family firms not involved in business partnerships, still remains.

The second limitation that requires attention is the method used in this project - PLS-SEM, which is a quantitative statistical method based on multivariate analysis. According to Hair et al. (2017) it could be used to answer research questions by confirming hypotheses or exploring patterns in the data, which completely fulfill the requirements for this study. However, if further investigation on the ways in which or how the family culture affects the performance of family firms is required, a qualitative method, with in-depth interviews, should be applied.

To conclude, aside from the usual limitations that most research projects are confronted by, the present work is limited because it analyzes organizations in the US retail industry and a variety of the strategic partnerships that they maintain to keep competitive, such as for new products, new technologies, and sustainability purposes. Further studies must be conducted to verify the impacts of family culture in family firms in a broader sense.

\subsubsection{Recommendations for Further Research}

The limitations mentioned above highlighted a considerable number of opportunities in this project that could be addressed through further investigation. However, those opportunities would confirm or reject the findings. From the perspective of this study, family culture is a relevant component of a family firm; therefore, a wider perspective to investigate culture in family firms should be proposed.

Culture plays an even more relevant role if different countries are considered. International management is a focal point for companies while they are trying to move their operations abroad 
(Zhang, Beatty, \& Walsh, 2008). The difference between national cultures and organizational cultures was highlighted by Hofstede (1994), who used a multinational corporation's (IBM ${ }^{4}$ ) operation in 64 different countries as his main source. Five different dimensions were proposed by Hofstede (1994) in order to classify the differences of cultures across countries. The first one is "power distance", which is related to the extent that the family accepts the disproportionate distribution of power. The second dimension is taking into consideration the extent that members are integrated into groups, in other words, "individualism versus collectivism". The third and fourth dimensions consider the differences between the distribution of power between men and women and the tolerance of the group of uncertainty and ambiguity. Finally, the fifth and last dimension proposed by Hofstede (1994) is differentiating cultures by whether the organization has a long- or short-term business orientation. Moreover, Hofstede (1994, p. 13) recommended that managers should acknowledge culturally different "organizational structures, leadership styles, motivation patterns, and training and development models" when expanding the company to new countries. However, to recognize those differences is superficial, due to the fact that the simple recognition does not explain how those distinct cultural aspects among countries affect firm management (Apetrei, Kureshi, \& Horodnic, 2015). The means and transitional behaviors that give rise to those distinct cultural backgrounds will determine how entrepreneurs analyze scenarios, make business decisions, and conduct their business. In conclusion, further investigation must be undertaken in order to analyze the impact of family culture on family firms when considering different countries, in other words, different cultures.

\footnotetext{
${ }^{4}$ International Business Machines Corporation (commonly cited as IBM) is an American multinational technology corporation with offices in over 170 countries.
} 
The influence of family culture on relationship value in family firms in retailer-vendor strategic partnerships, represented by Hypothesis 7 in this project, characterizes an opportunity for further research. Taking into consideration the PLS-MGA probabilities result between founders and successors for Hypothesis 7 at 0.07 , which is close to the 0.05 threshold proposed by Sarstedt et al. (2011), scholars should acknowledge that this result is not conclusive, in other words, further exploration should be considered. Following the rules of thumb proposed by Hair et al. (2017) the path coefficient from family culture to relationship value is weak at 0.114 for founders, which indicates that, for this group, family culture does not positively influence relationship value. On the other hand, the same path coefficient is moderately negative to successors at -0.438 , which indicates that, for this group, family culture does negatively influence relationship value. Given these mixed results future researchers may want to delve into this area further.

\subsection{Conclusion}

In light of the increase of business challenges, due to the global economy recession (Prabhakar, 2016), retail family firms and all aspects relative to it are a relevant subject to be studied and explored for years to come. For instance, recent articles are highlighting the increase of importance of family firms around the world (Mimili, Fang, Chrisman, \& Massis, 2015), especially in countries where the economy is drowning in a non-precedent crises, such as Brazil (Melo, 2015). Family firms, contrary to non-family firms, have to deal with emotional aspects and inter-personal dynamics, such as family conflicts (Astrachan et al., 2002), while creating jobs for next generations instead of focusing mainly on financial growth; therefore, family firms are helping to develop a better society (Wilson et al., 2014). 
From a retail standpoint, strategic partnerships are continuing, long-term relationships that consider strategic mutual purpose and result in profitability for both partners (Mentzer et al., 2000). They are an important business strategy for retailers (Porter, 1980). In the family business research, the impact of culture on performance has not been explored through the lens of retailervendor strategic partnerships, which is the focus of this project. All in all, retailers need to recognize not only the importance of family business but also family culture. In fact, since family culture impacts performance, retailers need to understand partners who are both founders and successors to develop a successful strategic partnership.

This study used Partial Least Squared Structural Equation Modeling (PLS-SEM) to accept four hypotheses as well as to reject four hypotheses. Two out of the three new hypotheses proposed by this project were confirmed, one in particular through a multi-group analysis, and this outcome consists of an important contribution of this work. One of the hypotheses that was accepted proposed a positive influence between family culture and performance, the main research question this project aimed to answer. Taking into consideration the reconstruction of family relations, the transfer of family influence, and the replacement of all organizational structures that are imposed on a family firm through a succession process (Lansberg, 1988), it was decided to move the investigation of this hypothesis further and test it between founders and successors.

On the one hand, for the founders' generation, family culture does not positively influence performance. On the other hand, the successors generation clearly considers family culture a positive influencer of family firms' performance in retailer-vendor strategic partnerships. Through the lens of these results, the interpretation to justify the response that family culture is 
not a positive driver of performance is because the founder of the firm is the personification of the family culture itself inside the firm (e.g., Gersick et al., 1997; Zaleznik \& Kets de Vries, 1985). The successors' response that family culture does positively influence performance is supported by the idea that successors have to keep the identity of the family in the firm while bringing forth their own experience and personally influence the organization (e.g., Cater et al., 2016; Handler, 1994).

This research and all its conclusions are far from being a definitive landmark; rather, this work represents a relevant step guiding scholars and practitioners to a better understanding of this complex subject that is family business in all its aspects and singularities. In addition to providing relevant and meaningful research, this study also aims to encourage scholars and practitioners to use this knowledge and grow eager to advancing the investigation of the remarkable field of family business. 


\section{Appendices}

\section{Reflective Constructs Loadings}

\begin{tabular}{|c|c|c|c|c|}
\hline & Commitment & Family Culture & Performance & Trust \\
\hline C1 & 0.931 & & & \\
\hline $\mathrm{C} 2$ & 0.911 & & & \\
\hline $\mathrm{C} 3$ & 0.892 & & & \\
\hline C4 & 0.796 & & & \\
\hline C5 & 0.891 & & & \\
\hline C6 & 0.89 & & & \\
\hline $\mathrm{C7}$ & 0.744 & & & \\
\hline FC1 & & 0.784 & & \\
\hline FC10 & & 0.863 & & \\
\hline FC11 & & 0.715 & & \\
\hline FC12 & & 0.666 & & \\
\hline FC13 & & 0.871 & & \\
\hline FC14 & & 0.744 & & \\
\hline $\mathrm{FC2}$ & & 0.807 & & \\
\hline FC3 & & 0.874 & & \\
\hline FC4 & & 0.838 & & \\
\hline FC5 & & 0.733 & & \\
\hline FC6 & & 0.849 & & \\
\hline FC7 & & 0.761 & & \\
\hline FC8 & & 0.8 & & \\
\hline FC9 & & 0.809 & & \\
\hline P1 & & & 0.861 & \\
\hline P2 & & & 0.919 & \\
\hline P3 & & & 0.906 & \\
\hline P4 & & & 0.908 & \\
\hline P5 & & & 0.923 & \\
\hline P6 & & & 0.853 & \\
\hline P7 & & & 0.854 & \\
\hline T1 & & & & 0.942 \\
\hline $\mathrm{T} 2$ & & & & 0.944 \\
\hline T3 & & & & 0.86 \\
\hline T4 & & & & 0.927 \\
\hline T5 & & & & 0.943 \\
\hline T6 & & & & 0.891 \\
\hline
\end{tabular}




\section{Reflective Constructs Cross Loadings}

\begin{tabular}{|c|c|c|c|c|c|}
\hline & Commitment & Family Culture & Performance & Relationship Value & Trust \\
\hline $\mathrm{C} 1$ & 0.931 & 0.088 & 0.306 & 0.527 & 0.742 \\
\hline $\mathrm{C} 2$ & 0.911 & 0.135 & 0.271 & 0.528 & 0.746 \\
\hline C3 & 0.892 & 0.158 & 0.268 & 0.534 & 0.737 \\
\hline C4 & 0.796 & 0.112 & 0.284 & 0.527 & 0.667 \\
\hline $\mathrm{C} 5$ & 0.891 & 0.012 & 0.256 & 0.539 & 0.713 \\
\hline $\mathrm{C6}$ & 0.89 & 0.081 & 0.333 & 0.593 & 0.724 \\
\hline C7 & 0.744 & 0.023 & 0.306 & 0.594 & 0.601 \\
\hline FC1 & 0.044 & 0.784 & 0.25 & 0.125 & 0.229 \\
\hline FC10 & 0.067 & 0.863 & 0.208 & 0.064 & 0.271 \\
\hline FC11 & 0.006 & 0.715 & 0.069 & -0.032 & 0.079 \\
\hline FC13 & 0.054 & 0.871 & 0.144 & 0.078 & 0.145 \\
\hline FC14 & 0.062 & 0.744 & 0.14 & 0.036 & 0.147 \\
\hline FC2 & 0.108 & 0.807 & 0.189 & 0.126 & 0.238 \\
\hline FC3 & 0.061 & 0.874 & 0.177 & 0.106 & 0.236 \\
\hline FC4 & 0.034 & 0.838 & 0.244 & 0.101 & 0.21 \\
\hline FC5 & 0.081 & 0.733 & 0.152 & 0.008 & 0.196 \\
\hline FC6 & 0.065 & 0.849 & 0.172 & 0.075 & 0.175 \\
\hline FC7 & 0.105 & 0.761 & 0.163 & -0.036 & 0.195 \\
\hline FC8 & 0.188 & 0.8 & 0.228 & 0.259 & 0.247 \\
\hline FC9 & 0.089 & 0.809 & 0.171 & 0.166 & 0.124 \\
\hline P1 & 0.29 & 0.135 & 0.861 & 0.516 & 0.329 \\
\hline $\mathrm{P} 2$ & 0.335 & 0.251 & 0.919 & 0.508 & 0.397 \\
\hline P3 & 0.229 & 0.261 & 0.906 & 0.427 & 0.322 \\
\hline P4 & 0.365 & 0.266 & 0.908 & 0.48 & 0.414 \\
\hline P5 & 0.33 & 0.142 & 0.923 & 0.512 & 0.352 \\
\hline P6 & 0.241 & 0.206 & 0.853 & 0.504 & 0.33 \\
\hline P7 & 0.281 & 0.2 & 0.854 & 0.536 & 0.247 \\
\hline RELV1 & 0.549 & 0.105 & 0.475 & 0.86 & 0.496 \\
\hline RELV2 & 0.494 & 0.01 & 0.328 & 0.689 & 0.466 \\
\hline RELV3 & 0.508 & 0.063 & 0.431 & 0.782 & 0.361 \\
\hline RELV4 & 0.114 & 0.064 & 0.197 & 0.259 & 0.135 \\
\hline RELV5 & 0.533 & 0.106 & 0.475 & 0.843 & 0.43 \\
\hline RELV6 & 0.434 & 0.006 & 0.409 & 0.698 & 0.362 \\
\hline $\mathrm{T} 1$ & 0.782 & 0.281 & 0.353 & 0.482 & 0.942 \\
\hline $\mathrm{T} 2$ & 0.804 & 0.22 & 0.401 & 0.525 & 0.944 \\
\hline T3 & 0.714 & 0.235 & 0.361 & 0.506 & 0.86 \\
\hline T4 & 0.706 & 0.282 & 0.315 & 0.412 & 0.927 \\
\hline T5 & 0.782 & 0.188 & 0.363 & 0.524 & 0.943 \\
\hline T6 & 0.685 & 0.194 & 0.314 & 0.481 & 0.891 \\
\hline
\end{tabular}


Formative Construct VIFs

\begin{tabular}{|l|c|}
\hline & VIF \\
\hline RELV1 & 1.838 \\
\hline RELV2 & 2.123 \\
\hline RELV3 & 2.71 \\
\hline RELV4 & 1.14 \\
\hline RELV5 & 2.067 \\
\hline RELV6 & 2.176 \\
\hline
\end{tabular}




\section{Data Construct Descriptions in Alphabetical Order}

\section{COMMITMENT - 7 Indicators and its respective theoretical origin.}

Scale- Strongly Agree $=7 /$ Strongly Disagree $=1$

The relationship my firm has with this strategic partner:

C1 ...is something we are very committed to. (Morgan \& Hunt, 1994)

C2 ...deserves our firm's maximum effort to maintain. (Morgan \& Hunt, 1994)

C3 ...is important to us in the long term. (Ganesan, 1994)

C4 ...is something my firm intends to maintain indefinitely. (Morgan \& Hunt, 1994)

C5 ...will be profitable in the long term. (Ganesan, 1994)

C6 ...focuses on long term goals. (Ganesan, 1994)

C7 ... is very much like being a family. (Morgan \& Hunt, 1994)

\section{DEMOGRAPHICS:}

D1 Title: Please select the title that closely represents your position in your organization:

D2 What were the revenues of your firm in 2011? Please select the appropriate category.

D3 Select the category that best describes your organization:

D4 What is your gender?

D5 What were the revenues of your major Strategic Partner in 2011?

D6 Your firm's perf. over last 3 years as a result of this SP

D7 Use a 0-100 slider scale to indicate the percent of goals attained with your major SP in 2011.

D8 Type of SP - My major Strategic Partner is a:

D9 How long have you worked with this Strategic Partner? Please slide the bar -no. years.

D10 How long has your organization maintained this Strategic Partnership? Please slide the bar D11 What is your age? Please key in the number of years in the box below.

D12 My company's head office is located in: (US, Canada) 


\section{FAMILY BUSINESS \& F-PEC SCALES}

FB1 Which of the following describes your relationship? (Founder, Descendent, In-Law...)

FB2 GEN Which generation do you represent?

\section{FAMILY CULTURE (F-PEC) - 14 Indicators and its respective theoretical origin. Scale- Strongly Agree=10/Strongly Disagree $=0$}

FC1 The owning family has influence on the business. (Astrachan et al., 2002)

FC2 The owning family members share similar values. (Astrachan et al., 2002)

FC3 The owning family members and the business share similar values. (Astrachan et al., 2002)

FC4 The owning family members are willing to put in a great deal of effort beyond that normally expected in order to help the family business to be successful. (Astrachan et al., 2002)

FC5 I support the family business in discussions with friends, employees, and other family members. (Astrachan et al., 2002)

FC6 I feel loyal to the family business. (Astrachan et al., 2002)

FC7 My values are compatible with those of the business. (Astrachan et al., 2002)

FC8 I am proud to tell others that we are part of the family business. (Astrachan et al., 2002)

FC9 There is so much to be gained by participating with the family business on a long-term basis. (Astrachan et al., 2002)

FC10 I agree with the family business goals, plans and policies. (Astrachan et al., 2002)

FC11 I really care about the fate of the family business. (Astrachan et al., 2002)

FC12 Deciding to be involved with the family business has a positive influence on my life. (Astrachan et al., 2002)

FC13 I understand the owning family's decisions regarding the future of the family business. (Astrachan et al., 2002)

FC14 I support the owning family's decisions regarding the future of the family business. (Astrachan et al., 2002) 
PERFORMANCE - 7 Indicators and its respective theoretical origin.

Please indicate the degree of satisfaction or dissatisfaction with the results achieved from the relationship with your major strategic partner over the last 3 to 5 years:

\section{Scale=Percentage satisfaction - Highly Satisfied $=100 /$ Very Dissatisfied $=0$}

P1 ...-Growth Objectives (Vázquez et al., 2005)

P2 ...-Sales Volume (Vázquez et al., 2005)

P3 ...-Gross Profit (Vázquez et al., 2005)

P4 ...Gross Margin Return on Investment (GMROI) (Vázquez et al., 2005)

P5 ...-Earnings Before Interest, Taxes, Depreciation and Amortization (EBITDA) (Vázquez et al., 2005)

P6 ...-The services provided by this Strategic Partner (Vázquez et al., 2005)

P7 ...-The resources invested in this Strategic Partner (Vázquez et al., 2005)

\section{RELATIONSHIP VALUE - 6 Indicators and its respective theoretical origin.}

\section{Scale-Strongly Agree $=10 /$ Strongly Disagree $=0$}

RELV1 Our company and my major Strategic Partner have compatible goals. (Vázquez et al., 2005)

RELV2 The relationship with my major Strategic Partner is mainly based on having similar points of view as to how to do business. (Vázquez et al., 2005)

RELV3 It would be difficult for our firm to replace the sales and profits generated from this major Strategic Partner. (Kumar, Scheer, \& Steenkamp, 1995)

RELV4 There are other vendors who could provide us with comparable product lines. (Kumar et al., 1995)

RELV5 Thanks to the cooperation between my company and this major Strategic Partner both parties have obtained strategic advantages over their competitors that would not have been feasible working individually. (Vázquez et al., 2005) 
RELV6 A large volume of profit both for my firm and this major Strategic Partnership would not have occurred working in isolation. (Ulaga \& Eggert, 2006)

\section{TRUST - 6 Indicators and its respective theoretical origin.}

Scale - Strongly Agree $=7 /$ Strongly Disagree $=1$

T1 This Strategic Partner is trustworthy. (Homburg, Cannon, Krohmer, \& Kiedaisch, 2009)

T2 We completely trust this Strategic Partner. (Homburg et al., 2009)

T3 This Strategic Partner can be counted on to do what is right. (Morgan \& Hunt, 1994)

T4 This Strategic Partner has high integrity. (Morgan \& Hunt, 1994)

T5 This major Strategic Partner is perfectly truthful. (Morgan \& Hunt, 1994)

T6 We can count on this Strategic Partner to keep its promises. (Homburg et al., 2009)

Text Boxes (Information was re-coded where possible. Participant may have been deleted based on what was written in text box.):

D1_11A TEXT My major Strategic Partner is a:-TEXT

D1_2ATEXT Please select the title that closely represents your position in your organization:TEXT

D1_4ASectTEXT You selected other in the previous question. Please tell us about the category that best describes $\mathrm{y} . .$.

FB1_1ATEXT Which of the following describes your relationship?-TEXT

IN_8ATEXT Other, please specify:

IN_8Text Other, please specify:

M_10ATEXT Other, Please specify:

M_10TEXT Other, Please specify:

D1_15 MyHOState Head office is located in:-State/Province:

D1_16 HOCity Head office is located in:-City:

D1_17 SPHO The head office of major Strategic Partner is located in: 


\section{References}

Ainsworth, S., \& Cox, J. W. (2003). Families divided: Culture and control in small family business. Organization Studies, 24(9), 1463-1485.

Allen, N., \& Meyer, J. (1990). The measurement and antecedents of affective, continuance and normative commitment to the organization. Journal of Occupational Psychology, 63(1), $1-18$.

Allison, P. (2012). When can you safely ignore multicollinearity? Statistical Horizons, September. Retrieved from https://statisticalhorizons.com/multicollinearity

Amy, H. (2016). Family businesses try to lift the second-generation curse. New York Times.

Apetrei, A., Kureshi, N. I., \& Horodnic, I. A. (2015). When culture shapes international business. Journal of Business Research, 68, 1519-1521.

Aronoff, C. (1998). Megatrends in family business. Family Business Review, 11(3), 181-192.

Astrachan, J. (1988). Family firm and community culture. Family Business Review, 1(2), 165 189.

Astrachan, J., Klein, S., \& Smyrnios, K. (2002). The F-PEC Scale of Family Influence: A Proposal for Solving the Family Business Definition Problem. Family Business Review, $X V(1), 45-58$.

Barach, J., \& Gantisky, J. (1995). Succesful succession in family business. Family Business Review, 8, 131-155.

Barach, J., Gantisky, J., Carson, J., \& Doochin, B. (1988). Entry of the next generation: Strategic challenge for family business. Journal of Small Business Management, 26, 49-57.

Barclay, D. W., Higgins, C. A., \& Thompson, R. (1995). The partial least squares approach to causal modeling: Personal computer adoption and use as illustration. Technology Studies, 2, 285-309.

Barney, J. (1986). Organizational culture: Can it be a source of sustained competitive advantage? Academy of Management Review, 11(3), 656-665.

Barney, J. (1991). Firm resources and sustained competitive advantage. Journal of Management, $17(1), 99-120$.

Becker, E. (1973). The denial of death. New York: Free Press.

Beckhard, R., \& Dyer, W. (1983a). Managing change in the family firm : Issues and strategies. Sloan Management Review, 24(59-65).

Beckhard, R., \& Dyer, W. (1983b). Managing continuity in the family-owned business. Organizational Dynamics, 12(1), 5-12.

Berle, A., \& Means, G. (1968). The modern corporation and private property. San Diego, California: Harcourt Brace Jovanovich.

Bird, B., Welsch, H., Astrachan, J. H., \& Pistrui, D. (2002). Family business research: The evolution of an academic field. Family Business Review, 15(4), 337-350.

Birley, S. (2002). Attitudes of owner-managers' children towards family and business issues. Entrepreneurship Theory and Practice, 26, 5-19.

Bjursell, C. (2011). Cultural divergence in merging family businesses. Journal of Family Business Strategy, 2, 69-77.

Blaikie, N. (2010). Designing Social Research (2nd ed.). Cambridge, UK: Polity Press. 
Bollen, K., \& Lennox, R. (1991). Conventional wisdom on measurement: A structural equation perspective. Psychological Bulletin, 1(10), 305-314.

Brun, S., Wrosch, C., \& Gagne, M. (2007). An exploration of the generational differences in levels of control held among family business approaching succession. Family Business Review, 20, 337-354.

Bryman, A. (2001). Social Research Methods. New York: Oxford University Press.

Bureau, U. S. o. A. (2012).

Cabrera-Suarez, K., De Saa-Perez, P., \& Garcia-Almeida, D. (2001). The succession process from a resource and knowledge-based view of the family firm. Family Business Review, 14, 37-47.

Cadieux, L., Lorrain, J., \& Hugron, P. (2002). Succession in women-owned family business: A case study. Family Business Review, 15, 17-30.

Carlock, R., \& Ward, J. (2001). Strategic planning for the family business - Parallel planning. Houndsmill, NY: Palgrave.

Carr, C., \& Bateman, S. (2010). Does culture count? Comparative performances of top family and non-family firms. International Journal of Cross Cultural Management, 10(2), 241262.

Carson, D., Gilmore, A., Perry, C., \& Gronhaug, K. (2001). Qualitative marketing research. London: Sage.

Casimiro, M., \& Chambel, M. (2014). Culture in small-sized Portuguese family business: Do first and second generations make a difference? The Journal of the Iberoamerican Academy of Management, 12(1), 40-67.

Cater, J., Kidwell, R., \& Camp, K. (2016). Successor team dynamics in family firms. Family Business Review, 29(3), 301-326.

Chami, R. (2001). What is different about family business? In S. El-Khouri (ed.), IMF working paper (pp.1-37), International Monetary Fund.

Chin, W. (2003). PLS Graph 3.0. Houston, TX: Soft Modeling, Inc.

Chirico, F., \& Nordqvist, M. (2010). Dynamic capabilities and trans-generational value creation in family firms: The role of organizational culture. International Small Business Journal.

Chrisman, J., Chua, J., \& Sharma, P. (1998). Important attributes of successors in family businesses: An exploratory study. Family Business Review, 11, 19-34.

Chrisman, J., Sharma, P., \& Taggar, S. (2007). Family influences on firms: An introduction. Journal of Business Research, 60, 1005 - 1011.

$\mathrm{Chu}, \mathrm{W}$. (2009). Family ownership and firm performance: Influence of family management, family control, and firm size. Springer Science + Business Media, LLC 2009(28), 833851.

Claessens, S., Djankov, S., Fan, J., \& Lang, L. (2002). Disentangling the incentive and entrenchment effects of large shareholdings. Journal of Finance, 57(6), 2741-2772.

Cohen, J. (1992). A power primer. Psychological Bulletin, 112, 155-159.

Connor, S. (1996). Postmodern performance, in: P. Campbell (Ed.), Analysing Performance. Manchester University Press, Manchester, UK.

Constantine, L. (1993). The structure of family paradigms: An analytical model of family variation. Journal of Marriage and Family Therapy, 19(1), 39-70.

Corbetta, G., \& Salvato, C. (2004). The board of directors in family firms: One size fits all? Family Business Review, 17(2), 119-134. 
Danco, L. (1982). Beyond survival. Cleveland: The University Press.

Davis, J., Allen, M., \& Hayes, H. (2010). Is Blood Thicker Than Water? A study of stewardship perceptions in family business. ET\&P.

Davis, P. (1986). Family business: Perspectives on change. Agency Sales Magazine, June, 9-16.

Davis, P., \& Harveston, P. (1999). In the founder's shadow: Conflict in the family firm. Family Business Review, 12(1), 311-323.

Deal, T., \& Kennedy, A. (1982). Corporate cultures. Reading: Addison-Wesley.

Debicki, B., Matherne III, C., Kellermanns, F., \& Chrisman, J. (2009). Family Business Research in the New Millennium, an overview of the who, the where, the what, and the why. Family Business Review, 22(2), 15.

Denison, D., Lief, C., \& Ward, J. (2004). Culture in Family-Owned Enterprises: Recognizing and Leveraging Unique Strengths. Family Business Review, XVII(no. 1), 61-70.

Deshpande, R., \& Webster, F. (1989). Organizational culture and marketing: Defining the research agenda. Journal of Marketing, 53(1), 3-15.

DeVellis, R. (1991). Scale development: Theory and applications. Newbury Park, CA: Sage.

Diamantopoulos, A., \& Winklhofer, H. (2001). Index construction with formative indicators: An alternative to scale development. Journal of Marketing Research, 38(2), 269-277.

Dillman, D., Smyth, J., \& Christian, L. (2009). Internet, mail, and mixed-mode surveys: The tailored design method (Vol. Third ed.): Hoboken: John Wiley \&amp; Sons Inc.

Donnelley, R. (1964). The family business. Harvard Business Review, 42(4), 93-105.

Dwyer, F., \& Tanner, J. (2002). Business Marketing: Connecting Strategy, Relationships, and Learning. New York: The McGraw-Hill Companies.

Dyer, W. (1986). Cultural change in family firms: Anticipating and managing business and family transitions. San Francisco: Jossey-Bass.

Dyer, W. (1988). Culture and continuity in family firms. Family Business Review, 1(1), 37-50.

Dyer, W. (2006). Examining the "Family Effect" on Firm Performance. Family Business Review, $X I X(4), 253-273$.

Eddleston, K., Chrisman, J., Steiler, L., \& Chua, J. (2010). Governance and trust in family firms: An introduction. Entrepreneurial: Theory and Practice, 34(6), 1043-1056.

Englisch, P., Hall, C., \& Astrachan, J. (2015). Staying power: How do family businesses create lasting success? Retrieved from

EY, K. S. U. (2015). Staying power: How do family business create lasting success? Global survey of the world's largest family businesses. Retrieved from http://www.ey.com/Publication/vwLUAssets/ey-staying-power/\$FILE/ey-staying-powerhow-do-family-businesses-create-lasting-success.pdf

FFI. (2012). Global data points: Family enterprise statistics from around the world. Retrieved from http://www.ffi.org/?page=GlobalDataPoints

Fletcher, D., Melin, L., \& Gimeno, A. (2012). Culture and values in family business - A review and suggestions for future research. Journal of Family Business Strategy, 3, 127-131.

Folan, P., Browne, J., \& Jagdev, H. (2007). Performance: Its meaning and content for today's business research. Computers in Industry, 58, 605-620.

Fowler, G. (2011). Living by the book of Apple --- Mac "Fanboys," who view tech company with religious fervor, sense void as leader steps aside. Wall Street Journal. 
Frank, H., Kessler, A., Rusch, T., Suess-Reyes, J., \& Weismeier-Sammer, D. (2016). Capturing the familiness of family businesses: Development of the family influence familiness scale (FIFS). Entrepreneurship Theory \& Practice(Advance online publication).

Frazier, G., Speckman, R., \& O'Neal, C. (1988). Just-In-Time Exchange Relationships in Industrial Markets. Journal of Marketing, 52(October), 52-67.

Galbraith, J. (1971). The New Industrial State. Boston: Houghton Mifflin.

Gallo, M. (2000). [Conversation with S. Klein at the IFERA meeting held at Amsterdam University, April 2000].

Ganesan, S. (1994). Determinants of long-term orientation in buyer-seller relationships. Journal of Marketing, 58, 1-19.

Garson, D. (2016). Partial least squares: Regression \&amp; structural equations model. NC, USA: Statistical Associates Publishing.

Gersick, K., Davis, J., McCollom, M., \& Lansberg, I. (1997). Generation to Generation: Life Cycles of the Family Business. Boston, MA: Harvard Business School Press.

Goffee, R., \& Jones, G. (1998). The character of the corporation: How your company's culture can make or break your business. New York: Harper Business.

Goffman, E. (1959). The Presentation of Self in Everyday Life. Boubleday, Garden City, New York, 17-24.

Hair, J., Hult, T., Ringle, C., \& Sarstedt, M. (2017). A primer on partial least squares structural equation modeling (PLS-SEM) (2nd ed.). Los Angeles: Sage.

Hair, J., Ringle, C., \& Sarstedt, M. (2011a). PLS-SEM: Indeed a silver bullet. Journal of Marketing Theory \& Practice, 19(2), 139-151.

Hair, J., Ringle, C., \& Sarstedt, M. (2011b). PLS-SEM: Indeed a silver bullet. Journal of Marketing Theory \&amp; Practice, 19(2), 139-151.

Hair, J., Sarstedt, M., Ringle, C., \& Gudergan, S. (2018). Advanced issues in partial least squares structural equation modeling. Los Angeles, USA: Sage Publications.

Hair, J., Sarstedt, M., Ringle, C., \& Mena, A. (2012). An assessment of the use of partial least square structural equation modeling in marketing research. Journal of the Academy of Marketing Science, 40, 414-433.

Han, S., Wilson, D., \& Dant, S. (1993). Buyer supplier relationships today. Industrial Marketing Management, 22(4), 331-338.

Handler, W. (1994). Succession in family business: A review of the research. Family Business Review, $\operatorname{VII}(2), 133-155$.

Henseler, J. (2007). A new and simple approach to multi-group analysis in Partial Least Squares path modeling. Nijmegen School of Management, 1-4.

Henseler, J., \& Dijkstra, T. (2015). ADANCO 1.1. Retrieved from http://www.compositemodeling.com/

Henseler, J., Dijkstra, T., Sarstedt, M., Ringle, C., Diamantopoulos, A., \& Straub, D. (2014). Common beliefs and reality about partial least squares: Comments on Ronkko \&amp; Evermann (2013). Organizational Research Methods, 4.

Henseler, J., Ringle, C., \& Sarstedt, M. (2016). Testing measurement invariance of composites using partial least squares. International Marketing Review, 33(3), 405-431.

Hofer, C. (1983). A new measure for assessing organization performance. Advances in Strategic Management, 2, 43-55. 
Hofstede, G. (1980). Cultures' consequences: International differences in work related values. Beverly Hills, CA: Sage.

Hofstede, G. (1994). The business of international business is culture. International Business Review, 3(1), 1-14.

Hogan, J. (2001). Expected relationship value. A construct, e methodology for measurement, and a modeling technique. Industrial Marketing Management, 30, 339-351.

Holland, P., \& Oliver, J. (1992). An empirical examination of stages of development of family business. Journal of Business \&amp; Entrepreneurship, 4(3), 27 - 38.

Hollander, B., \& Bukowitz, W. (1990). Women, Family Culture, and Family Business. Family Business Review, III(2), 139-151.

Homburg, C., Cannon, J. P., Krohmer, H., \& Kiedaisch, I. (2009). Governance of international business relationships: A cross-cultural study on alternative governance modes. Journal of International Marketing, 17, 1-20.

Hubona, G. (2015). PLS-GUI. Retrieved from http://www.pls-gui.com/

Hudson, L., \& Ozanne, J. (1988). Alternative ways of seeking knowledge in consumer research. Journal of Consumer Research, 14(4), 508-521.

Hult, G., Hurley, R., \& Knight, G. (2003). Innovativeness: Its antecedents and impact on business performance. Industrial Marketing Management, 33(2004), 429-438.

Huntley, J. (2006). Conceptualization and measurement of relationship quality: Linking relationship quality to actual sales and recommendation intention. Industrial Marketing Management, 35(6), 703-714.

Hutt, M., Stafford, E., Walker, B., \& Reinge, P. (2000). Defining the social network of a strategic alliance. Sloan Management Review, 41(2), 51-62.

Ingram, H. (1996). Linking teamwork with performance. Team Performance Management: An International Journal, 2(4), 5-10.

Jamie, L. (2015). Family feud disrupts DARCARS. Automotive News.

Jaskiewicz, P., Heinrichs, K., Rau, S., \& Reay, T. (2016). To be or not to be: How family firms manage family and commercial logics in succession. Entrepreneurship Theory and Practice, 7, 781-813.

Joyce, W., \& Slocum, J. (1984). Collective climate: Agreement as a basis for defining aggregate climates in organizations. Academy of Management Journal, 27(December), 721-742.

Kansikas, J., \& Kuhmonen, T. (2008). Family business succession: evolutionary economics approach. Journal of Enterprise Culture, 16(3), 279-298.

Kantor, D., \& Lehr, W. (1975). Inside the Family. San Francisco, CA: Jossey-Bass.

Kaplan, P. (2014). Kaplan construction [Press release]

Kelly, L., Athanassiou, N., \& Crittenden, W. (2000). Founder centrality and strategic behavior in the family-owned firm. Entrepreneurship Theory and Practice, 25(2), 27-42.

Klein, S. (1991). Der Einflu $\beta$ von Werten auf die Gestaltung von Organisationen. Berlin: Duncker \&amp; Humblot.

Klein, S., Astrachan, J., \& Smyrnios, K. (2005). The F-PEC Scale of Family Influence: Construction, Validation, and Further Implication for Theory. Entrepreneurship Theory and Practice, 321-339.

Kock, N. (2015). WarpPLS 5.0 user manual. Laredo, TX: ScriptWarp Systems.

Kotter, J., \& Heskitt, J. (1992). Corporate culture and performance. New York: Free Press. 
Kumar, N., Scheer, L., \& Steenkamp, J. (1995). The effects of perceived interdependence on dealer attitudes. Journal of Marketing Research (JMR), 32, 348-356.

Lansberg, I. (1988). The succession conspiracy. Family Business Review, 1(2), 119-143.

Lebas, M. (1995). Performance measurement and performance management. International Journal of Production Economics, 41, 23-35.

Lohmoller, J. (1987). LVPLS 1.8. Cologne, Germany: Zentralarchiv fur Empirische Sozialforschung.

Luhmann, N. (1995). Social systems. Stanford, CA: Stanford University Press.

Lumpkin, G., Martin, W., \& Vaughn, M. (2008). Family orientation: Individual-level influences on family firm outcomes. Family Business Review, 21(2), 127-138.

Mayer, R., Davis, J., \& Schoorman, F. (1995). An integrative model of trust. Academy of Management Review, 20(3), 709-734.

McClelland, D. (1961). The achieving society. Princeton, N.J.: Van Nostrand Reinhold.

McConaughy, D., \& Phillips, G. (1999). Founders versus descendants: The profitability, efficiency, growth characteristics and financing in large, public, founding-familycontrolled firms. Family Business Review, 12(2), 123-131.

McKenzie, J. (2001). Performance or Else. Routledge, London/New York, 49-53.

Melo, L. (2015). No Brasil, empresas familiares cresceram mais que no mundo. Exame.

Mentzer, J., Min, S., \& Zacharia, Z. (2000). The nature of interfirm partnering in supply chain management. Journal of Retailing, 76(4), 549-568.

Meyer, J., \& Herscovitch, L. (2001). Commitment in the workplace: Toward a general model. Human Resource Management Review, 11(3), 299-326.

Milton, L. (2008). Unleashing the relationship power of family firms: Identify confirmation as a catalyst for performance. Entrepreneurship: Theory and Practice, 32(6), 1063-1081.

Mimili, E., Fang, H., Chrisman, J., \& Massis, A. (2015). The impact of small- and medium-sized family firms on economic growth. Small Business Economics, 45(4), 771-785.

Mooney, L., Knox, D., \& Schacht, C. (2007). Understanding social problems (5th ed.). Belmont, CA: Thomson Wadsworth.

Morgan, R., \& Hunt, S. (1994). The commitment-trust theory of relationship marketing. Journal of Marketing, 58(3), 20-38.

Morris, H., Williams, R., Allen, J., \& Avila, R. (1997). Correlates of success in family business transitions. Journal of Business Venturing, 12, 385-401.

Mowday, R., Porter, L., \& Steers, R. (1982). Organizational linkages: The psychology of commitment, absenteeism, and turnover. New York: Academic Press.

Nelton, S. (1986). Making sure your business outlasts you. Nations Business, Jan, 32-38.

Norus`is, M. (2009). PASW statistics 18 statistical procedures copmanion. Upper Saddle River: Prentice Hall.

Nunnally, J., \& Bernstein, I. (1994). Psychometric theory. New York: McGraw-Hill.

O'Reilly III, C., Chatman, J., \& Caldwell, D. (1991). People and organizational culture: A profile comparison approach to assessing person-organization fit. The Academy of Management Journal, 34(3), 487-516.

Pascale, R., \& Athos, A. (1981). The art of Japanese management. New York: Simon and Schus.

Phelan, P. (1993). The ontology of performance: Representation without reproduction, unmarked: The politics of performance. Routledge, London/New York, 146-166.

Plunkett, J. (2013). Plunkett's retail industry almanac 2014. Houston: Plunkett Research, Ltd. 
Podsakoff, P., MacKenzie, S., Podsakoff, N., \& Lee, J. (2003). Common method biases in behavioral research: A critical review of the literature and recommended remedies. Journal of Applied Psychology, 88(5), 879-903.

Porter, M. E. (1980). Competitive strategy: Techniques for analyzing industries and competitors. New York: Free Press.

Poza, E. (2007). Family Business. New York: Thonson South-Western.

Prabhakar, A. (2016). The current global recession: A theoretical and empirical investigation into developed and BRICS economies. ProQuest Ebook Central, http://ebookcentral.proquest.com.ezproxy.lib.ryerson.ca/lib/ryerson/detail.action?docID= 4717041: Emerald Group Publishing Limited.

Pradhan, S., \& Ranajee, J. (2012). Value creation by family-owned businesses: A literature review. IUP Journal of Business Strategy, 9(4), 35-45.

PWC. (2014). These figures were prepared for the National Retail Federation (NRF) and use the North American Industry Classification System (NAICS) codes for Retail Trade (44-45) and Food Services and Drinking Places (NAICS 722 only).

PwC. (2014). Up close and professional: the family factor. Global family business survey. Retrieved from

Richer, N., Sinkovics, R., Ringle, C., \& Schlagel, C. (2016). A critical look at the use of SEM in international business research. International Marketing Review, 33(3), 376-404.

Rigdon, E. (2012). Rethinking partial least squares path modeling: In praise of simple methods. Long Range Planning, 45, 341-358.

Riketta, M. (2002). Attitudinal organizational commitment and job performance. A metaanalysis. Journal of Organizational Behaviour, 23(3), 257.

Ringle, C., Wende, S., \& Becker, J. (2015). SmartPLS 3. Retrieved from http://www.smartpls.com/

Ringle, C., Wende, S., \& Will, A. (2005). SmartPLS 2.0. Hamburg, Germany: University of Hamburg. Retrieved from http://www.smartpls.com/

Rod, I. (2016). Disentangling the family firm's innovation process: A systematic review. Journal of Family Business Strategy, 7, 185-201.

Rokeach, M. (1973). The nature of human values. New York: Free Press.

Rousseau, D., Sitkin, S., Burt, R., \& Camerer, C. (1998). Not so different after all: A crossdiscipline view of trust. Academy of Management Review, 23(3), 393-404.

Ryssel, R., Ritte, T., \& Gemunden, H. (2004). The impact of information technology deployment on trust, commitment and value creation in business relationships. The Journal of Business \&amp; Industrial Marketing, 19(3), 197-207.

Sarstedt, M., Henseler, J., \& Ringle, C. (2011). Multigroup analysis in Partial Least Squares (PLS) Path Modeling: Alternative methods and empirical results. Advances in International Marketing, 22, 195-218.

Sarstedt, M., \& Ringle, C. (2010). Treating unobserved heterogeneity in PLS path modelling: A comparison of FIMIX-PLS with different data analysis strategies. Journal of Applied Statistics, 37, 1299-1318.

Sarstedt, M., Ringle, C., Smith, D., Reams, R., \& Hair, J. (2014). Partial least squares structural equation modeling (PLS-SEM): A useful tool for family business researchers. Journal of Family Business Strategy, 5, 105-115. 
Schechner, R. (1988). Performance studies: the broad spectrum approach. Journal of Performance Studies, 32(3), 4-6.

Schein, E. (1983). The role of the founder in creating organizational culture. Organizational Dynamics, 12(1), 13-28.

Schein, E. (1985). Organizational Culture and Leadership: A dynamic view. San Francisco CA: Jossey-Bass.

Schein, E. (1995). The role of the founder in creating organizational culture. Family Business Review, 8(3), 221-238.

Schein, E., \& Schein, P. (2017). Organizational culture and leadership (5th ed.). New Jersey, USA: Wiley.

Shapero, A. (1975). The displaced, uncomfortable entrepreneur. Psychology Today, Nov., 83-86.

Sharma, P., Chrisman, J., \& Chua, J. (1997). Strategic management of the family business: Past research and future challenges. Family Business Review, 10(1), 1-36.

Sharma, P., Chrisman, J., \& Chua, J. (2003). Succession planning as planned behavior: Some empirical results. Family Business Review, 16, 1-15.

Sharma, P., \& Irving, P. (2005). Four bases of family business successor commitment: Antecedents and consequences. Entrepreneurship: Theory and Practice, 29(1), 13-33.

Sharma, P., \& Manikutty, S. (2005). Strategic divestments in family firms: Role of family structure and community culture. Entrepreneurship: Theory and Practice, 29(3), 293311.

Sharma, P., \& Rao, S. (2000). Successor attributes in Indian and Canadian family firms: A comparison study. Family Business Review, 13(313-330).

Sieger, P., Bernhard, F., \& Frey, U. (2011). Affective commitment and job satisfaction among non-family employees: Investigating the roles of justice perception and psychological ownership. Journal of Family Business Strategy, 2(2), 78-89.

Sindhuja, P. N. (2009). Performance and Value Creation: Family Managed Business Versus Non-Family Managed Business. IUP Journal of Business Strategy, 6(3/4), 66-80.

Sirmon, D., \& Hitt, M. (2003). Managing resources: Linking unique resources, management, and wealth creation in family firms. Entrepreneurship: Theory \&amp; Practice, 27(4), 339358.

Smircich, L. (1983). Concepts of culture and organizational analysis. Administrative Science Quarterly, 28(3), 339-358.

Smith, D. (2011). A model for retailer-vendor strategic partnerships: Development and empirical investigation. (Doctor of Business Administration), Henley Business School, University of Reading,

Smith, D. (2016). Overview of retailing in US.

Smith, D., Hair, J., \& Ferguson, E. (2014). An investigation of the effect of family influence on commitment-trust in retailer-vendor strategic partnerships. Journal of Family Business Strategy, 119, 1-12.

Sonfield, M., \& Lussier, R. (2004). First-, second-, and third-generation family firms: A comparison. Family Business Review, 17(3), 189-202.

Spector, P. (1992). Summated ratings scales constructions. Newbury Park, CA: Sage.

Stamm, I., \& Lubinski, C. (2011). Crossroads of family business research and firm demography a critical assessment of family business survival rates. Journal of Family Business Strategy, 2(3), 117-127. 
Steir, L. (2001). Family firms, plural forms of governance, and the evolving role of trust. Family Business Review, 14(4), 353-367.

Stern, L., El-Ansary, A., \& Coughlan, A. (1996). Marketing Channel. 5 Cliffs, NJ: Prentice Hall. Sundaramurthy, C. (2008). Sustaining trust within family business. Family Business Review, 21(1), 89-102.

Tagiuri, R., \& Davis, J. (1996). Bivalent attributes of the family firm. Family Business Review, 9(2), 199-208.

Thomas, L. (2012). Best Buy hits the road. Star Tribune.

Top, S., Atan, O., \& Dilek, E. (2013). Evaluation of family effects in the context of power, experience and culture on business and management in the family firms. Procedia Social and Behavioral Sciences, 99, 956-965.

Ulaga, W., \& Eggert, A. (2006). Relationship value and relationship quality. European Journal of Marketing, 40(3/4), 311-327.

Vallejo, M., \& Langa, D. (2010). Effects of family socialization in the organizational commitment of the family firms from the moral economy perspective. Journal of Business Ethics, 96(1), 49-62.

Venkatraman, N., \& Ramanuja, V. (1986). Measurement of business performance in strategic research: A comparison of approaches. Academy of Management Review, 11(4), 801-814.

Von Schlippe, A., \& Frank, H. (2013). The theory of social systems as a framework for understanding family businesses. Family Relations, 62(3), 384-398.

Vázquez, R., Iglesias, V., \& Álvarez-González, L. (2005). Distribution channel relationships: The conditions and strategic outcomes of cooperation between manufacturer and distributor. International Review of Retail, Distribution \& Consumer Research, 15(2), 125-150.

Ward, J. (1987). Keeping the family business healthy. San Francisco: Jossey-Bass.

Westhead, P., \& Howorth, C. (2007). Types of private firms: An exploratory conceptual and empirical analysis. Entrepreneurship and Regional Development, 19, 405 - 431.

Wilson, S. R., Whitmoyer, J. G., Pieper, T. M., Astrachan, J. H., Hair, J. F., \& Sarstedt, M. (2014). Method trends and method needs: Examining methods needed for accelerating the field. Journal of Family Business, 5, 4-14.

Wortman, M. (1994). Theoretical foundations for family-owned business: A conceptual and research-based paradigm. Family Business Review, 7(1), 3-27.

Zahra, S., \& Filatotchev, I. (2004). Governance of the entrepreneurial threshold firm: A knowledge-based perspective. Journal of Management Studies, 41(5), 883-895.

Zahra, S., Hayton, J., Neubaum, D., Dibrell, C., \& Craig, J. (2008). Culture of family commitment and strategic flexibility: The moderating effect of stewardship. Entrepreneurship: Theory and Practice, 32(6), 1035-1064.

Zahra, S., \& Sharma, P. (2004). Family business research: A strategic reflection. Family Business Review, 17(4), 331-346.

Zaleznik, A., \& Kets de Vries, M. (1985). Power and the corporate mind. Chicago: Bonus.

Zhang, J., Beatty, S., \& Walsh, G. (2008). Review and future directions of cross-cultural consumer services research. Journal of Business Research, 61(3), 211-224. 